Mônica Lupião Lobarinhas

\title{
Análise de possibilidades e limites de comunicação pública da ciência realizada através do Laboratório de Poluição Atmosférica Experimental da Faculdade de Medicina da Universidade de São Paulo
}

Tese apresentada à Faculdade de Medicina da Universidade de São Paulo para obtenção do título de Doutor em Ciências.

Área de concentração: Patologia.

Orientador: Prof. Dr. Alfésio Luis Ferreira Braga

Co-orientadora: Prof ${ }^{a}$. Dr ${ }^{\mathrm{a}}$. Martha Marandino

São Paulo 
Mônica Lupião Lobarinhas

\section{Análise de possibilidades e limites de comunicação pública da ciência realizada através do Laboratório de Poluição Atmosférica Experimental da Faculdade de Medicina da Universidade de São Paulo}

Tese apresentada à Faculdade de Medicina da Universidade de São Paulo para obtenção do título de Doutor em Ciências.

Área de concentração: Patologia.

Orientador: Prof. Dr. Alfésio Luis Ferreira Braga

Co-orientadora: Prof ${ }^{a}$. Dr ${ }^{\mathrm{a}}$. Martha Marandino

São Paulo 
Dados Internacionais de Catalogação na Publicação (CIP)

Preparada pela Biblioteca da

Faculdade de Medicina da Universidade de São Paulo

Creprodução autorizada pelo autor

Lobarinhas, Mônica Lupião

Análise de possibilidades e limites de comunicação pública da ciência realizada através do Laboratório de Poluição Atmosférica Experimental da Faculdade de

Medicina da Universidade de São Paulo / Mônica Lupião Lobarinhas. -- São Paulo, 2008.

Tese(doutorado)--Faculdade de Medicina da Universidade de São Paulo.

Departamento de Patologia.

Área de concentração: Patologia.

Orientador: Alfésio Luis Ferreira Braga.

Co-orientadora: Martha Marandino.

Descritores: 1.Comunicação em saúde 2.Percepção pública da ciência 3. Saúde ambiental 4.Pesquisa qualitativa 5.Relações interprofissionais 6.Informação pública 
Sos mens pais, Pepe e Marly. que do outro lado da vida se orgulham deste momento. 


\section{AGRADECIMENTOS}

Meus agradecimentos sinceros a cada um de vocês...

Prof. Dr. Alfésio Luis Ferreira Braga e à Prof ${ }^{a}$. Drª . Martha Marandino que, indo muito além de suas responsabilidades como orientadores, me auxiliaram de forma única. Ficarão para sempre em minha memória como profissionais de excelência e amigos diletos.

Prof. Dr. Luiz Alberto Amador Pereira, por sua contribuição decisiva em vários momentos desta trajetória, desde a elaboração à qualificação. Injusto seria não registrar a personalidade rara e especial deste professor e amigo com quem tive a imensa satisfação de conviver e aprender.

Prof. Dr. Paulo Hilário do Nascimento Saldiva, pelo apoio, dedicação e exemplo como pesquisador e ser humano.

Toda a equipe de cientistas do LPAE e da FMUSP pela colaboração e sugestões oportunas: Prof ${ }^{\mathrm{a}} \mathrm{s}$. Dr ${ }^{\mathrm{a}} \mathrm{s}$. Ana Júlia de Faria Coimbra Lichtenfels, Dolores Helena Rivero, Heloísa Maria Bueno Guimarães, Mariângela Macchione, Marisa Dolhnikoff, Míriam Lemos, Regiani Carvalho de Oliveira; Profs. Drs. Chin An Lin, José Eduardo Delfini Cançado e Marcos Abdo Arbex.

Prof ${ }^{a} s$. Dr ${ }^{\mathrm{a}} \mathrm{s}$. Helena Ribeiro, Marisa Domingos, Eliane Tigre Guimarães Sant'Anna e à Profạ. Débora-Jã de Araújo Lobo por suas idas à Baixada Santista e aporte distinto neste trabalho.

Eliane Falconi Mônico Gazetto e Maria Dalva Gomes Santana, secretárias do LPAE, pela colaboração paciente.

Profạ. Josélia Paixão e Silva, diretora da Escola Estadual José da Costa Sobrinho, por sua parceria como educadora compromissada, facilitando-nos o trabalho. 
Todos os professores de Ensino Básico e jornalistas que se disponibilizaram a participar, permitindo que este estudo pudesse acontecer.

E, com menção direta do coração, recebam meu muito obrigada, meu afeto e meu carinho....

Nilva Nunes Campina, amiga ímpar, pelas colaborações inúmeras e fundamentais, pelo estímulo, força, exemplo, enfim, pelo privilégio de ter compartilhado estes anos árduos de pesquisa e estudo com alguém tão especial e sem a qual este trabalho nem sequer teria se iniciado.

Ana Lúcia, Ana Caetano, Míriam, Mônica e Zezé, queridas amigas, através das quais me reconheço e aprendo, pelo apoio afetuoso, pela compreensão e aceitação.

Denise Marino, cara e bem humorada amiga, pelas contribuições perspicazes e inteligentes.

Ariadne, pelo auxílio tão importante nas transcrições, pela paciência na convivência, pelo carinho e dedicação incondicionais.

Cinthia e Rebecca, irmãs tão amadas e queridas, pela atenção e preocupação constantes, pelo suporte material e emocional nas horas mais difíceis, pelo ombro amigo, por se colocarem para sempre no meu coração.

Áureo e André, caríssimos cunhados, um pouco irmãos, pelas colaborações inúmeras e pelo exemplo cotidiano no trabalho.

Fernanda Ariel, Nicolas, Pietra e Filippo, sobrinhos adorados, pela infância reluzente que me enche de alegria e esperanças. 
Carlos Eduardo, companheiro querido, pelas leituras cuidadosas, opiniões importantes, estímulo, apoio, compreensão, dedicação e, principalmente, por me ensinar diariamente a ser melhor.

Hannah, filha amada, pedacinho luminoso e radiante da minha vida, por ter sido o motivo único para retomar quando eu já havia desistido. 
Pedras no camínho?

Guardo todas, um día

vou construir um castelo...

Fernando Pessoa 


\section{Resumo}

\section{Sumário}

Summary

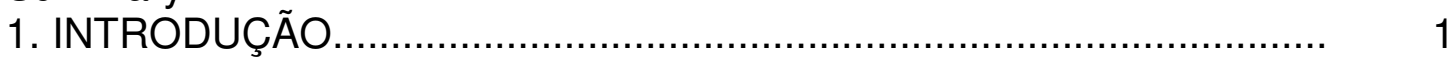

1. 1. O objeto de estudo................................................................

1.1.1. Laboratório de Poluição Atmosférica Experimental: da 4 estruturação aos dias atuais...

1.1.2. LPAE e a mídia não acadêmica................................................. 10

1.1.3. LPAE e promoção de Educação Ambiental................................... 12

1.1.3.1. Projeto Coração Roxo.............................................................. 13

1.1.3.2. Projeto Estação Ambiência..................................................... 15

1.1.3.2.1. Curso Poluição e Saúde - Projetos Ambientais e a Escola..... 16

1.1.3.2.2. Supervisão e Acompanhamento............................................ 21

1.1.3.3. Projeto Biomonitoramento e Promoção da Saúde...................... 24

1.1.4. Comunicação para além da academia: diferentes possibilidades.. 25

1.1.5. O LPAE e a transmissão do conhecimento: sobre a socialização do saber

1. 2. Estruturação do estudo.............................................................. 29

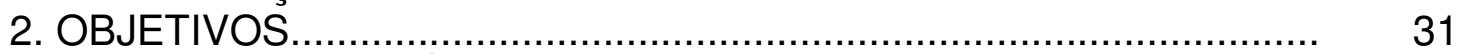

3. REFERENCIAL TEÓRICO......................................................

3. 1. Pesquisa qualitativa................................................................. 33

3. 1.1. Breve histórico ..................................................................... 34

3. 1.2. Em busca de um paradigma qualitativo...................................... 37

3. 1.3. Cenário atual........................................................................ 40

3. 1.4. Conceituações atuais da pesquisa qualitativa............................. 41

3. 2. Comunicação de massa e Comunicação Pública da Ciência........... 43

3. 2.1. Modelos de Comunicação Pública da Ciência.............................. 47

3. 2. 2. 1. Modelo de déficit............................................................... 47

3. 2. 2. 2. Outras propostas............................................................. 49

3. 2. 2. 3. Modelo contextual........................................................... 50

3. 2. 2. 4. Modelo de experiência leiga................................................. 50

3. 2. 2. 5. Modelo de participação pública.............................................. 51

3. 3. Educação Ambiental.................................................................. 52

3. 3.1. Educação Escolar: um foco nas questões ambientais................... 52

3. 3.2. Caminhos Percorridos pela Educação Ambiental......................... 55

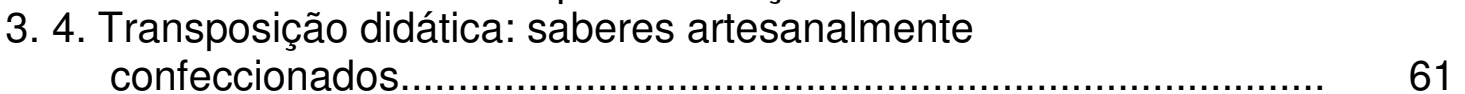

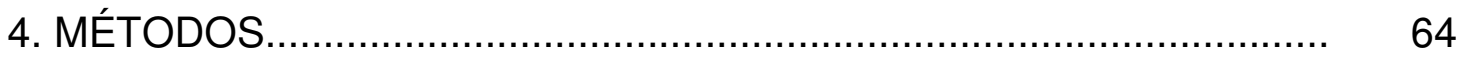

4. 1. Etapas de desenvolvimentos da pesquisa........................................ 64

4. 1.1. Sujeitos da pesquisa............................................................ 65

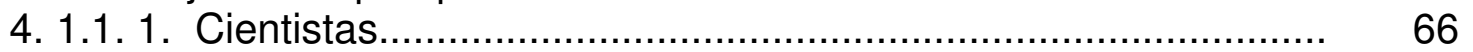

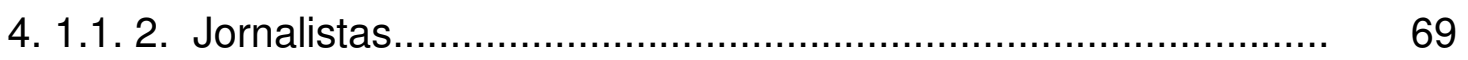

4. 1.1. 3. Professores......................................................................... 71

4. 2. Procedimentos de coleta e análise de dados.................................. 71

4. 2.1. Levantamento documental..................................................... $\quad 72$

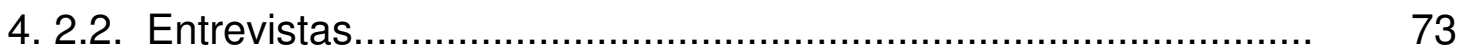

4. 2.3. Questionários...............................................................

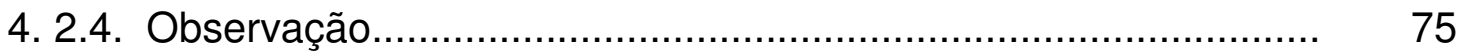

4. 2.5. Análise de conteúdo............................................................ 77 
5. RESULTADOS.... 79

5. 1. LPAE e a mídia não acadêmica................................................ 79

5. 1.1. Levantamento das publicações científicas................................. 79

5. 1.2. Levantamento das comunicações não acadêmicas..................... 80

5. 1.3. Entrevistas realizadas com os cientistas.................................. 83

5. 1.3. 1. Origem motivadora ................................................... 83

5. 1.3. 2. Inserção na comunidade científica......................................... 84

5. 1.3. 3. Inserção junto ao público não acadêmico................................. 85

5. 1.3. 4. Vontade expressa: interferir na política ambiental.................... 87

5. 1.3. 5. Possibilidades de compreensão........................................... 87

5. 1.4. Questionários realizados com os jornalistas.............................. 89

5. 2. LPAE e promoção de Educação Ambiental...................................... 93

5. 2.1. Projeto Coração Roxo............................................................ 93

5. 2.2. Projeto Estação Ambiência................................................... 94

5. 2.2. 1. Curso "Poluição E Saúde - Projetos Ambientais e a Escola"... 94

5. 2.2. 2. Supervisão e Acompanhamento............................................... 96

6. DISCUSSÃO..................................................................... 99

6.1. A CPC praticada pelo LPAE através da mídia................................ 99

6.2. A CPC praticada pelo LPAE através das escolas............................ 104

6.3. A CPC sob a ótica de quem faz e de quem divulga ciência............. 109

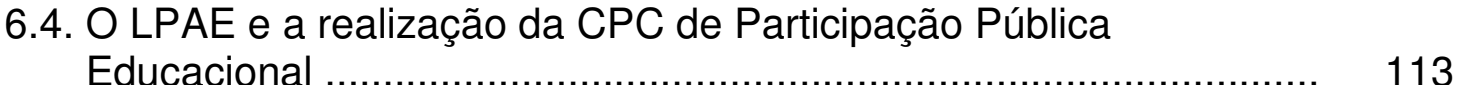

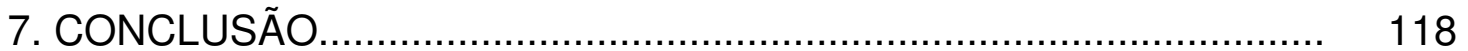

8. ANEXOS .......................................................................... 121

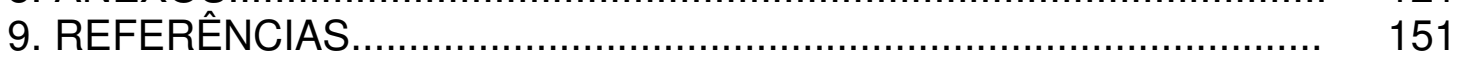


Lobarinhas ML. Análise de possibilidades e limites de comunicação pública da ciência realizada pelo Laboratório de Poluição Atmosférica Experimental da Faculdade de Medicina da Universidade de São Paulo [tese]. Faculdade de Medicina, Universidade de São Paulo; 2008.

INTRODUÇÃO: Tem-se afirmado que a divulgação da ciência ao público não acadêmico permite uma atuação mais efetiva nas intervenções que possam daí advir, sejam educacionais, culturais ou relacionadas à saúde. OBJETIVO: Analisar as possibilidades e limites de atuação de um Laboratório de produção científica do porte do Laboratório de Poluição Atmosférica Experimental (LPAE) da Faculdade de Medicina da Universidade de São Paulo em Comunicação Pública da Ciência. MÉTODOS: Utilizou-se como referencial metodológico a pesquisa qualitativa. Foram levantadas todas as publicações do LPAE de janeiro de 1982 a junho de 2007; quatorze cientistas do LPAE foram entrevistados; 19 jornalistas que contataram o LPAE para realização de entrevistas que envolveram este laboratório entre janeiro de 2006 e junho de 2007 responderam a um questionário; e foram levantadas as ações de educação ambiental realizadas pelo LPAE. RESULTADOS: A comunicação pública da ciência realizada pelo LPAE ocorre através de todos os veículos de comunicação da mídia não acadêmica de forma constante. A percepção de divulgação pela imprensa não acadêmica é bastante discordante entre o grupo de cientistas pesquisados. Observa-se certa insatisfação manifesta por alguns, indicando que gostariam que essa inserção fosse mais expressiva. Alguns cientistas defendem a idéia de que todas as pesquisas podem ser transmitidas ao público não acadêmico enquanto outros declaram haver limites para a transmissão dessas informações. Ao analisarmos as relações entre jornalistas e cientistas, observamos importantes pontos de conflitos. Os cientistas criticam o despreparo destes para a entrevista. Jornalistas percebem suas relações com os cientistas em claro desequilíbrio onde o cientista se entende ocupando um lugar de destaque. Entre os jornalistas emerge a noção de direito da mídia, a ser exercido a fim de transpor as barreiras entre a academia e os demais membros da sociedade. Apontam dificuldades relacionadas à compreensão da linguagem utilizada, ao entendimento do processo científico, desconfiança da academia em relação à imprensa, pouca abertura dos cientistas a outras opiniões e difícil acesso ao cientista. As ações do LPAE em parceria com escolas de Ensino Básico têm conseguido alcançar total ou parcialmente seus objetivos tanto com o corpo docente como com o discente. Este estudo propõe uma subcategoria de modelo de comunicação pública da ciência denominada de modelo de participação pública educacional. Tanto professores de Ensino Básico como cientistas demonstraram interesse no trabalho em conjunto. Porém, as ações somente ocorreram quando intermediadas por um profissional ligado tanto ao LPAE quanto à escola. CONCLUSÃO: Ao longo de sua existência, o LPAE vem se mantendo na mídia não acadêmica constantemente. Vários pontos de tensão emergiram nas declarações tanto de cientistas como de jornalistas permitindo uma avaliação das principais questões que permeiam as relações entre estes profissionais. É possível e de interesse tanto de professores como de cientistas o intercâmbio de forma continuada entre os centros de produção científica e a escola básica. Entretanto, a estruturação das redes públicas de ensino não estimula tal prática, dificultando a implantação ou continuidade de iniciativas deste porte. Para que se tornem viáveis, é necessário um profissional responsável pela intermediação do processo.

Descritores: 1. Comunicação em saúde 2. Percepção pública da ciência 3. Saúde ambiental 4. Pesquisa qualitativa 5.Relações interprofissionais 6.Informação pública 

Lobarinhas ML. Possibilities and limits analyzes of Science Public Communication by Laboratory of Experimental Atmospheric Pollution from the University of São Paulo [thesis]. Faculty of Medicine, University of São Paulo, SP (Brazil); 2008.

INTRODUCTION: Many authors have stated that the popularization of the science to the nonacademic public allows a more effective performance in educational, cultural or health-related interventions that can occur. OBJECTIVE: Analyze the acting possibilities and limits of a scientific production laboratory with the importance of the Laboratory of Experimental Air Pollution (LPAE) from the University of São Paulo Faculty of Medical Sciences in Public Communication of the Science. METHODS: The qualitative research was the methodological reference adopted in this study. All papers published by LPAE, from January 2006 to June 2007 were analyzed; fourteen LPAE's researchers were interviewed; nineteen journalists that contacted LPAE for accomplishment of interviews that involve this laboratory between January of 2006 and June of 2007 answered a questionnaire; and environmental education actions accomplished by LPAE were surveyed. RESULTS: The science public communication accomplished by LPAE happens through all of the nonacademic media communication vehicles in a constant way. The perception of the disclosure by the nonacademic press is very discordant among the researchers group. Certain dissatisfaction is manifested by some of the researchers, indicating that they would like a more expressive insertion. Some of them assume that all researches can be transmitted to the nonacademic public, while some of them declare that there are limits to the transmission of that information. The analysis of the relationship between journalists and scientists reveals important conflict points. The scientists criticize the journalists' unpreparedness to the interview. Journalists indicate that they perceive an unbalanced relationship, where the scientists put themselves in a prominence place.

Among the journalists the notion of right of the media emerges, to be exercised in order to transpose the barriers between the academy and the other members of the society. They point out difficulties related to the comprehension of the language used and the understanding of scientific process, distrust of the academy in relation to the press, little opening of the scientists to other opinions and difficult access to the scientist. The LPAE actions in partnership with Basic Schools have reached total or partially their objectives with both the teachers and the students. This study proposes a subcategory of the public communication of science denominated education public participation model. Both teachers of elementary schools and scientists demonstrated interest in working together. However the actions only happened when intermediated by a professional linked to both LPAE and the school. CONCLUSION: Along its existence, the LPAE remains in the nonacademic media in a constant way. Several tension points emerged in declarations of both journalists and scientists allowing an evaluation of the main subjects that permeate the relationships among these professionals It is possible and of interest to the teachers and scientists the exchange in a continuous way between the scientific production centers and the basic school. However the public schools net structuring does not stimulate such practice, hindering the implantation or the continuity of initiatives of this load. To make them viable, it is necessary a responsible professional for the intermediation of the process.

Descriptors: 1-Health communication 2- Public perception of science 3-Environmental health 4-Qualitative research 5-Interprofissional relations 6-Public information 


\section{CAPÍTULO 1: INTRODUÇÃO}

"A Ciência moderna produz conhecimentos e desconhecimentos. Se faz do cientista um ignorante especializado, faz do cidadão comum um ignorante generalizado."

Boaventura Sousa Santos'

A história da humanidade é a história de uma espécie que, desde os primórdios da sua própria existência, vem procurando compreender e utilizar a natureza e seus recursos de forma a beneficiar-se. Por necessidade de sobrevivência, busca por conforto ou mera curiosidade, a civilização se fez através de e pela busca do conhecimento.

Com o decurso dos tempos os campos de estudo foram se delimitando e separando uns dos outros, atravessando, cada qual à sua vez, a linha divisória entre o conhecimento intuitivo e a ciência ${ }^{1}$. Os homens e mulheres responsáveis pela produção deste conhecimento sempre, de alguma forma, se diferenciaram. Amados e condecorados, uns, execrados e condenados à morte, outros, desde os "guardiões do fogo"2 aos cientistas e pesquisadores atuais, estas pessoas vem se distinguindo exatamente por não apenas saberem, mas sobretudo, por gerarem saberes. E é a estes produtores de conhecimentos a quem cabe a responsabilidade da decisão, ao menos em um primeiro momento, se este novo saber terá seu acesso ao grande público, ao não cientista, facilitado. Muitas das publicações científicas

\footnotetext{
I Um discurso sobre as ciências. $8^{\mathrm{a}}$ ed. Porto: Edições Afrontamento;1996.
} 
tornaram-se e tornam-se inacessíveis ao público comum em conseqüência de fatores como a linguagem utilizada, a abstração e o entendimento de paradigmas pressupostamente sabidos ${ }^{1}$.

Tanto na Matemática como na Astronomia, já na Antiguidade os relatórios de pesquisas deixaram de ser inteligíveis para um auditório dotado de cultura geral. Na Dinâmica, a pesquisa tornou-se igualmente esotérica nos fins da ldade Média (...). A pesquisa elétrica começou a exigir uma tradução para leigos no fim do século XVIII. Muitos outros campos da ciência física deixaram de ser acessíveis no século XIX. Durante esses mesmos dois séculos, transições similares podem ser identificadas nas diferentes áreas das ciências biológicas. ${ }^{1}$

Alguns teóricos especulam que a idéia de divulgar a ciência é bastante antiga, remontando ao século $\mathrm{XVII}{ }^{3} \mathrm{Na}$ atualidade, vem sendo motivo de estudos e debates tanto em universidades e instituições de pesquisa como entre jornalistas e estudiosos da comunicação. José Reis, um dos mais renomados teóricos brasileiros na área de divulgação científica, nos diz:

A divulgação científica radicou-se com o propósito de levar ao grande público, além da notícia e interpretação dos progressos que a pesquisa vai realizando, as observações que procuram familiarizar esse público com a natureza do trabalho da ciência e a vida dos cientistas. Assim conceituada, ela ganhou grande expansão em muitos países, não só na imprensa, mas sob forma de livros e, mais refinadamente, em outros meios de comunicação de massa ${ }^{3}$.

Alguns autores apontam, ainda, que "a divulgação ao público leigo possibilita uma maior legitimação social à atividade científica”, além de permitir uma atuação mais efetiva nas intervenções que possam daí advir, 
sejam educacionais, culturais ou relacionadas à saúde - tanto individual como coletiva.

O conhecimento, burilado e acumulado por milênios, chega aos dias atuais com uma imensa carga de informação, tanto em termos quantitativos como qualitativos. Torná-lo de domínio público é um desafio - quase mesmo uma provocação - a ser enfrentado dentro da comunidade científica por todos aqueles comprometidos com os ideais de eqüidade e democracia da nossa era. É neste contexto, a partir dos caminhos buscados por este compromisso, que esta pesquisa se encontra.

\section{1. O objeto de estudo}

O Laboratório de Investigação Médica 05 (LIM-05) é uma divisão de pesquisa do Departamento de Patologia do Hospital das Clínicas da Faculdade de Medicina da Universidade de São Paulo (HCFMUSP), e é denominado, através de regimento interno, de Laboratório de Patologia Experimental. Contudo tornou-se conhecido, tanto nos meios acadêmicos como fora deles, pelo nome fantasia: Laboratório de Poluição Atmosférica Experimental (LPAE).

Este laboratório vem produzindo ao longo da sua existência uma grande quantidade de material científico, sendo reconhecido nacional e internacionalmente pela alta qualidade dos seus trabalhos, tanto em poluição atmosférica e seus efeitos à saúde como em outros campos como estudos epidemiológicos, investigações toxicológicas e pesquisas citogenéticas. Uma 
parcela dos resultados destas pesquisas consegue extrapolar os limites do âmbito acadêmico e científico.

Apresentaremos a seguir os principais aspectos do LPAE: seu histórico, estruturação atual, sua relação com a mídia e suas tímidas inserções no campo da Educação Ambiental.

\subsubsection{Laboratório de Poluição Atmosférica Experimental: da estruturação aos dias atuais}

Em decorrência da Reforma Universitária de 1969 foram criados, através da Lei de Diretrizes e Bases da Educação Nacional, os Laboratórios de Investigação Médica (LIM) como unidades do Hospital das Clínicas (HC). Este hospital, por sua vez, é uma Autarquia Estadual, associada à Universidade de São Paulo (USP) para fins de ensino, pesquisa e serviços de comunidade ${ }^{5}$.

Com o objetivo de manutenção da pesquisa básica, foi firmado um convênio entre o $\mathrm{HC}$ e a Faculdade de Medicina (FMUSP) através do qual os LIM passam a ocupar o espaço físico da FMUSP e a receber materiais e recursos humanos do Hospital.

Este convênio vigorou até abril de 1977, quando, através do Decreto 9720, os 62 LIM existentes são incorporados às Unidades Hospitalares do HC. Estas Unidades são vinculadas aos Departamentos da FMUSP e possuem as finalidades elencadas a seguir: 
- desenvolver pesquisa científica;

- padronizar novas técnicas e métodos de diagnóstico possibilitando sua implantação para atendimento de pacientes em outras Unidades do HC;

- promover a formação de pesquisadores em pesquisa básica e aplicada;

- servir de campo de ensino e treinamento de estudantes de escolas de nível superior, cujos currículos sejam relacionados com as ciências da saúde;

- servir de campo de desenvolvimento e treinamento para profissionais de saúde;

- realizar cursos no campo da medicina e da saúde.

No ano de 1995 é aprovado o Regimento Interno dos LIM através do qual cada Laboratório recebe, oficialmente, denominação específica. O LIM05 é denominado de Laboratório de Patologia Experimental ${ }^{5}$.

O chefe do LPAE, Prof. Dr. Paulo Saldiva, nos explica melhor esta questão da nomenclatura:

(...) quando houve a reforma universitária, (...) as cadeiras básicas que estavam aqui nessa faculdade tinham que se mudar pra USP, pro campus da USP. (...) de repente, começou a aparecer um monte de espaço vazio nessa faculdade, e aí veio até uma idéia de que esse prédio fosse a academia de policia. Numa tentativa de manter a Faculdade de Medicina e de restaurar a pesquisa dentro dessa faculdade, (...) se criou um instituto dos Laboratórios de Investigação Médica, que na época foram 62 e foi criado (...) um Decreto Lei, (...) aprovado na Assembléia Legislativa e se deram nomes, e este Laboratório 05 era 0 
Laboratório de Patologia Experimental. (...) isso aconteceu no final dos anos 60 e, com o tempo viraram outros nomes de fantasiall.

O LPAE, um Laboratório cuja proposta básica é pesquisar poluição atmosférica, nasce de uma adversidade. A idéia da formação do Laboratório surge em meados da década de 1970, como conseqüência de uma mudança nos padrões de linhas de financiamento a pesquisadores, financiamentos estes que passam a privilegiar a pesquisa aplicada, ou pesquisa dirigida, em detrimento da chamada pesquisa pura. Nessa época, o médico, pesquisador e professor húngaro Dr. György Miklós Böhm, radicado no Brasil desde 1947 e que então ocupava a cadeira de professor titular na Faculdade de Medicina de Ribeirão Preto, percebe que os estudos que vinha desenvolvendo poderiam ser ameaçados pela ausência de recursos financeiros. O próprio Dr. Böhm conta um pouco desta história ao escrever o editorial do Jornal de Pneumologia:

"O Laboratório de Poluição Atmosférica Experimental do Departamento de Patologia da FMUSP (LPAE) nasceu de um susto. No começo de 75 ressurgiu, com vigor, aquela burrice que de quando em vez zurra no país: o apoio preferencial das agências científicas oficiais à pesquisa aplicada com prejuízo correspondente à pesquisa pura. Não há pesquisa pura e aplicada: só há a boa e a má. Mas vá explicar! Seja como for, naqueles tempos dedicava-me à microcirculação pulmonar de ratos e a possibilidade de ficar sem auxílio me pareceu real. Tinha um convite para fazer uma conferência em maio daquele ano, em Paris. Providencial. Fui ao "St. Bartolomew's Hospital" para consultar o meu guru, Prof. W.G.Spector. Ouviu, pensou e telefonou ao Prof. P. Lawther. Marcamos o encontro para já no "White Hart" e lá, numa mesa aconchegante do pub Iondrino, com o apoio das

\footnotetext{
${ }^{\text {II }}$ Entrevista concedida em 31/01/2006 a esta autora.
} 
cabeças dos chefes do Departamento de Patologia e do Laboratório de Poluição do velho "Bart's", surgiu a idéia de investigar a poluição atmosférica no Brasil $O$ pedido inicial foi apresentado à FAPESP e, graças aos esforços do Prof. W.S. Hossne, o projeto 75/1200 foi aprovado dois anos depois, em 1977, quando me mudei de Ribeirão Preto para São Paulo. A instalação de um laboratório que pretende trabalhar com $A R$ numa Faculdade de Medicina é uma loucura só imaginável por quem já a fez. Levou dois anos e bastante. Em 1979 apareceram alguns malucos que completaram a obra e o LPAE virou realidade." ${ }^{6}$

No final da década de 1970, com a vinda do Dr. Böhm para a Faculdade de Medicina da USP e a obtenção do maior crédito até então liberado pela Fundação de Amparo à Pesquisa do Estado de São Paulo (FAPESP) inicia-se a montagem do LPAE. Naturalmente alguns obstáculos precisariam ser superados, sendo o maior deles, a dificuldade de encontrarse material específico para as pesquisas que principiavam.

Duas "molas" propulsionaram os trabalhos começantes. A primeira delas, o desafio ao qual o Laboratório havia se proposto e que justificou a sua própria criação: avaliar a qualidade do ar, a princípio na cidade de São Paulo, e associá-la à saúde de sua população. Já a segunda vem de uma decisão político-econômica, tomada pelo governo federal, que marcaria o país pelas décadas seguintes: a proposta de mudar a matriz energética dos veículos automotores no Brasil de gasolina para álcool. O LPAE realiza, então, um estudo comparativo entre ambos os componentes em termos de toxicidade. 
Dentre os primeiros trabalhos publicados pelo Laboratório estão "Air Pollution and Lung Cancer"ll e "Comparative Toxicity of Alcohol and Gasoline Fueled Automobile Exhaust Fumes",IV, de 1982 e 1983, respectivamente, e vêem de encontro aos propósitos iniciais. Ambos trazem ao LPAE, já nos seus primeiros anos de criação, reconhecimento e credibilidade em termos de seriedade e compromisso com a pesquisa, além de considerável notoriedade, principalmente com o segundo estudo citado, que aponta o álcool como um combustível menos tóxico quando comparado à gasolina.

Em 2006, com a aposentadoria do Dr. Böhm, a chefia do LPAE é assumida por Paulo Hilário do Nascimento Saldiva. Ex-aluno do Dr. Böhm e, assim como este, médico patologista, pesquisador e professor titular da FMUSP, Dr. Saldiva já atuava como chefe oficioso, colaborando ativamente com Dr. Böhm, desde o final dos anos 80, período em que este se envolve com outros assuntos da FMUSP ao assumir o cargo de diretor da Fundação Faculdade de Medicina.

Segundo Dr. Saldiva, que auto define-se como "um regente de competências ou de habilidades de uma estrutura caótica", atualmente não há um organograma no LPAE:

(...) não funciona num organograma, ele (o LPAE) se organizou (...) num modelo (...) muito parecido com os anarquistas espanhóis, onde as comunas se organizavam baseadas no que as pessoas sabiam

\footnotetext{
III Böhm, GM. Câncer Detec.Prev., vol.5: 371-374;1982.

IV Böhm, GM, Massad, E; Saldiva, PHN; Gouveia, MA; Pasqualucci, CA; Cardoso, LMN; Caldeira, MPR; Calheiros, DF. In: Developments in the Science and Practice of Toxicology by A.W.Hayes R.C.Scnell and T.S.Miya.: 479-482 Elsevier Science Publishers B.V. Amsterdan; 1983.
} 
fazer, então as pessoas se organizaram de acordo com o que elas sabem fazer.

(...) o equilíbrio está em você aceitar esta diversidade e compor um quebra cabeças onde as pessoas encontram um espaço pra trabalhar dentro desse sistema. $^{V}$

Apesar de Dr. Böhm e Dr. Saldiva terem estilos de trabalho diferentes "porque eu (Saldiva) sou um individuo anárquico, (...) meu sistema de organização é diferente, e ele (Böhm) tem um sistema baseado numa hierarquia, numa outra coisa completamente diferente", - ambos conseguiram ajustar suas divergências no modo de trabalhar e, durante os anos em que exerceram a chefia conjuntamente, conduzem o LPAE de forma que a equipe incremente a produção de pesquisas de alto nível técnico, com grande aceitação pelo meio acadêmico, permitindo um número cada vez maior de publicações em revistas e jornais científicos.

No momento deste estudo o LPAE tem seu foco dividido em três áreas principais, que são:

- $\quad$ avaliação do impacto da poluição - não só atmosférica, como também da água e do solo - na saúde da população, buscando um determinante da relação saúde-doença;

- $\quad$ patologia humana, pulmonar - avaliação de neoplasias e doenças inflamatórias de vias aéreas;

- ensino, em nível de pós-graduação e graduação. Nesta linha podem ser incluídas tanto as experiências de ensino à distância, que

\footnotetext{
${ }^{\mathrm{V}}$ Entrevista concedida em 31/01/2006 a esta autora.
} 
veremos a seguir, como os vários alunos de graduação que realizam seus trabalhos de iniciação científica no LPAE.

$\mathrm{Na}$ área de ensino encontra-se uma das importantes contribuições do LPAE com a criação da disciplina de Informática Médica, hoje disponível para os alunos de pós-graduação, surgida no Laboratório, conforme nos diz Dr. Böhm em entrevista concedida em 1996:

Para que pudéssemos verificar o efeito da poluição em ratos, nós precisávamos fazer uma prova de função pulmonar. Isso é difícil em animais e precisamos desenvolver um programa especial, com informações on line. Um grupo começou a brincar com informática para resolver esse problema e foi então que surgiu pela primeira vez a nova disciplina na universidade. ${ }^{7}$

Métodos alternativos de medida de poluição - como biomonitoramento estudos epidemiológicos, investigações toxicológicas e pesquisas citogenéticas são consideradas as linhas básicas de pesquisa do LPAE que produz um considerável número de trabalhos, muitos deles de interesse do grande público, que geraram e geram reportagens e entrevistas divulgadas na mídia não acadêmica, como veremos adiante.

Tendo sido traçado um panorama do LPAE, discutiremos agora sobre duas questões pertinentes a este estudo: a comunicação do LPAE com o público não acadêmico e, posteriormente, suas possibilidades de articulações com este público através da Educação Ambiental.

\subsubsection{LPAE e a mídia não acadêmica}

A primeira publicação científica do LPAE acontece em 1982 e, de lá para cá, centenas de publicações vem sendo realizadas em jornais e 
revistas científicas que apresentam focos variados de pesquisa como Chest: The Cardiopulmonary and Critical Care Journal, Environmental Research, Thorax Journal, European Respiratory Journal, Archives of Environmental Health, American Journal Respiratory and Critical Care Medicine, Journal of Epidemiology and Community Health, European Heart Journal, Cadernos de Saúde Pública, Brazilian Journal of Medical and Biological Research entre outros. Parte dos resultados destes trabalhos atrai a mídia não acadêmica dando origem a uma série de entrevistas, reportagens, artigos e sítios da Worldwide Web capazes de permitir uma popularização científica ${ }^{\mathrm{VI}}$ das informações produzidas a um grande número de pessoas fora da área acadêmica ou científica, divulgando uma parcela da sua produção.

Abordaremos com mais detalhes, no Capítulo 3, alguns estudos que vem sendo realizados em relação aos diferentes entendimentos dados às formas de Comunicação Pública da Ciência (CPC). No entanto, algumas rápidas considerações se fazem necessárias, ao buscarmos embasamento no referencial teórico utilizado para a proposta de analisarmos a CPC realizada pelo LPAE.

Consideramos redundância dizer que nenhum tipo de comunicação possa se dar de forma unilateral. Paulo Freire ${ }^{8}$ iniciou essa discussão na área da educação na década de 1960, tirando do professor o foco da

\footnotetext{
${ }^{\mathrm{VI}}$ Utilizou-se, aqui, o termo popularização científica de acordo com Massarani. Segundo esta autora, existe uma hegemonia quanto ao uso da expressão divulgação científica e propõe este termo como sinônimo de vulgarização, popularização e comunicação pública, diferenciando-os de difusão e disseminação. Como divulgação entende-se "o envio de mensagens elaboradas mediante a transcodificação de linguagens, transformando-as em linguagens acessíveis para a totalidade do universo receptor." (Massarani, 1998:13)
} 
aprendizagem e colocando-a no processo, para o qual educador e educandos têm o mesmo valor, desempenhando, apenas, papéis diferentes. E, fundamental ressaltar, compete ao primeiro a responsabilidade por conduzir a ação de forma a respeitar as características particulares de uma determinada comunidade, porém sem perder de vista interesses mais amplos pois, segundo este autor, somos todos cidadãos do mundo ${ }^{8}$. Da mesma forma, entendemos que cientistas e não cientistas devem fazer parte do processo de CPC.

Desde o início desta pesquisa havia o dado empírico de que a comunicação com a mídia era realizada com sucesso pela equipe do LPAE, mais especificamente pela pessoa de seu chefe, Dr. Saldiva. Adiante, analisaremos os materiais disponíveis sobre essa divulgação.

\subsubsection{LPAE e a promoção de Educação Ambiental}

Educar para a conservação do meio ambiente é um conceito que pode ser considerado novo. Adquiri vigor, a partir da Europa, em meados da década de 1960, sendo que, no Brasil, apenas em 1973 é incluído na legislação brasileira e vem ganhar uma Diretoria específica dentro do Ministério do Meio Ambiente - a Diretoria de Educação Ambiental - somente em 1999.

Dentro do LPAE, a parceria com a educação básica é uma idéia trazida por Dr. Saldiva já no final da década de 1980. Apesar disso, durante cerca de quinze anos apenas contatos pontuais foram realizados com as escolas, através de algumas visitas de grupos de alunos e palestras ministradas 
pelos componentes do Laboratório. Somente em 2001 inicia-se uma interação sistematizada de Educação Ambiental, promovida com a chegada ao LPAE de profissionais ligadas à educação formal não acadêmica, a Prof ${ }^{a}$. Nilva Nunes Campina e esta autora. A partir daí, algumas ações de maior impacto na comunidade escolar foram desencadeadas: o Projeto Coração

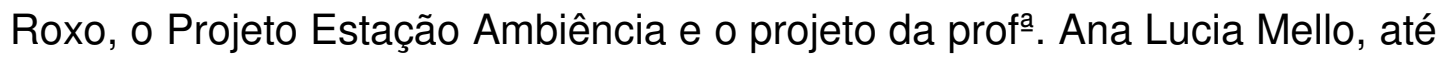
então denominado Metodologias Participativas e Biomonitoramento: Promoção da Saúde no Distrito de Vicente de Carvalho, Guarujá/SP.

\subsubsection{Projeto Coração Roxo}

Iniciado em 2001, com a proposta de que alunos da rede básica realizassem o biomonitoramento tanto atmosférico na cidade de Cubatão (SP) como da água do rio de mesmo nome, este projeto, inicialmente coordenado pelas professoras anteriormente citadas, vem sendo realizado com alunos de Ensino Médio da Escola Estadual (EE) Professor José da Costa, localizada no município de Cubatão. Utiliza-se de duas técnicas amplamente exploradas pelo Laboratório: o teste de micronúcleo (TRADMNC) e o teste dos pêlos estaminais, ambos realizados utilizando-se a Tradescantia ${ }^{V I I}$ como bioindicador.

Com alguns objetivos diretamente ligados ao controle de poluentes, como estabelecer e disponibilizar um panorama da poluição do ar em diversas regiões da cidade bem como da água do rio Cubatão e analisar as condições de qualidade da água utilizada pela população da região da

\footnotetext{
VII planta da família Commelinaceae que vem sendo amplamente utilizada para o monitoramento de poluentes ambientais.
} 
Baixada Santista, propõe, também, algumas análises no campo pedagógico. São elas: avaliar as possibilidades de uma pesquisa científica ser desenvolvida por alunos da escola pública, avaliar se estes alunos são capazes de produzir informações úteis à sua comunidade utilizando-se dos resultados obtidos e avaliar se estes alunos são capazes de levar estas informações à sua comunidade.

Para que sua implementação pudesse ser realizada, seria necessária a concordância da direção da escola como o apoio do corpo docente. Inicialmente, foi contatada a diretora da EE Marechal Humberto Castelo Branco, em Cubatão. Apesar da anuência desta diretora e de formar-se um grupo de alunos interessados em participar nesta escola, alguns problemas como a ausência constante dos alunos e a falta de um espaço adequado para o desenvolvimento das atividades dificultaram a continuidade do trabalho. Foi, então, contatada a diretora da EE José da Costa, na mesma cidade, que solicitou uma apresentação da proposta ao professores, que aprovaram a idéia.

Para a escolha dos alunos, inicialmente foi sorteada uma das seis classes de primeiro ano do Ensino Médio, então existentes na escola, pretendendo-se que todos participassem. Porém, após um período, optou-se por trabalhar com alunos oriundos de quaisquer das classes de primeiro ano, mas que mostrassem interesse.

Depois de formado o grupo, foi realizado o mapeamento da cidade e escolhidos os locais de observação. 
Alguns encontros entre os pesquisadores ligados ao LPAE e os alunos participantes tem sido propiciados por este projeto. Estes têm acontecido em vindas dos pesquisadores à escola tanto para discussão de temas teóricos relevantes como para o ensino das técnicas de biomonitoramento bioensaio da avaliação de mutações em pêlos estaminais de Tradescantia (para o estudo na atmosfera) e bioensaio de micronúcleos em células mãe de pólen de Tradescantia pallida realizados in situ (para o estudo na água).

Em 2003 foi condecorado com o Prêmio Construindo a Nação ${ }^{\text {VIII, }}$ tornando-se, no ano seguinte, objeto de estudo da tese de doutoramento da Profa ${ }^{-}$Nilva Nunes Campina.

Entre 2006 e 2007 recebeu financiamento da Petrobrás (Cia. De Petróleo Brasileiro S.A.), através do Projeto Remar, linha de financiamento direcionado a projetos que contribuam para dar maior sustentabilidade, geração de renda e qualidade de vida às populações carentes.

\subsubsection{Projeto Estação Ambiência}

Dentro da proposta de aproximação do LPAE com o ensino não acadêmico, foram elaboradas no ano de 2005, uma série de atividades que previam a formação de uma "estação" de ensino, denominada Estação Ambiência, conforme descrevemos a seguir.

Em março de 2005 foi contatada, pelo Dr. Saldiva e por esta autora, a Dirigente Regional de Ensino de Santos, responsável pela Diretoria de Ensino da Região de Santos (DER-Santos). Este órgão é uma das Diretorias

\footnotetext{
VIII Premiação conferida a trabalhos desenvolvidos por alunos de Ensino Médio do Estado de São Paulo que abordem temas relacionados à cidadania. É uma iniciativa do Instituto Brasileiro da Cidadania e tem o apoio do governo do Estado de São Paulo e de diversas empresas e entidades.
} 
de Ensino da Rede Estadual de Educação de São Paulo e ao qual respondem as escolas estaduais dos municípios de Santos, Cubatão, Guarujá e Bertioga.

Entendendo que a proposta apresentada era abrangente o suficiente para interessar às demais Diretorias de Ensino do Estado de São Paulo, a Dirigente recomendou-nos à Coordenadoria de Estudos e Normas Pedagógicas (CENP), da Secretaria de Estado da Educação, onde foram efetuados contatos com a responsável pela coordenação da Educação Ambiental. Esta sugeriu a realização de um "curso piloto" na Baixada Santista.

Paralelamente, foi também realizado o contato com o Secretário Municipal de Educação de Cubatão que prontamente interessou-se pela parceria.

A proposta feita nestes encontros foi a de formação de um núcleo de ensino onde fosse possível desenvolver, junto às escolas de Ensino Fundamental, atividades voltadas para as questões ambientais, utilizando-se das pesquisas e produções do Laboratório. Devidamente redigida, esta proposta foi entregue aos representantes da Educação Estadual e Municipal citados acima, recebendo a denominação de Projeto Estação Ambiência.

\subsection{Curso Poluição e Saúde - Projetos Ambientais e a Escola}

Para viabilizar o Projeto Estação Ambiência, a princípio foi oferecido um curso aos professores de Ensino Fundamental e Médio, com aulas ministradas, em sua maioria, pela equipe do LPAE. Com o intento de 
oferecer subsídios que proporcionassem embasamento para a compreensão ampla das propostas do LPAE, também contou-se com a participação de professores de áreas afins da Universidade de São Paulo. Para tanto foram incluídas aulas de Metodologia de Projetos e Geografia Ambiental além de biomonitoramento de Ozônio, esta última realizada mediante parceria com o Departamento de Ecologia do Instituto de Botânica de São Paulo.

O objetivo centrava-se, em um primeiro momento sensibilizar e, seqüencialmente, dar o suporte teórico necessário para o desenvolvimento de projetos, a serem realizados com os alunos, pelos professores capacitados.

Foi, então, enviado um convite às escolas de ambas as redes de ensino, sendo que os professores da rede municipal tiveram dispensa de ponto para participação no curso, o mesmo não ocorrendo na rede Estadual, onde os professores interessados em participar deveriam fazê-lo fora de seu horário de trabalho.

Intitulado Poluição e Saúde - Projetos Ambientais e a Escola (POSPAE), o curso foi oferecido a professores do Ensino Fundamental e Médio, de quaisquer áreas do conhecimento, com uma carga horária de 64 horas, sendo 40 horas presenciais (10 encontros semanais de 4 horas cada) e 24 horas na escola, para desenvolvimento dos projetos.

A DER-Santos cedeu o espaço de uma de suas escolas em Cubatão, a EE José da Costa, para a realização das aulas teóricas e a Secretaria de 
Educação (SEDUC) Cubatão ofereceu alimentação, além de ter se responsabilizado pelo transporte dos professores ministrantes.

A estruturação do curso baseou-se em possibilitar que os professores participantes tivessem uma noção dos principais estudos que são desenvolvidos pelo LPAE para que, a partir das técnicas ou conceitos neles utilizados, pudessem desenvolver projetos em suas escolas. Naturalmente, priorizou-se aqueles que apresentavam alguma viabilidade de ser desenvolvido, parcial ou totalmente, dentro das escolas.

Foram realizadas várias aulas teóricas e práticas e também foi proporcionada uma visita ao Laboratório a fim de que os professores participantes tivessem um contato direto para melhor se apropriarem de todas as explanações que vinham sendo feitas até então. A Secretaria de Educação de Cubatão cedeu um ônibus com motorista para que a viagem pudesse acontecer.

Efetivado no período de 29/08/2005 a 03/11/2005 das $13 \mathrm{~h} 30$ às $17 \mathrm{~h} 30$, teve a programação constante na página seguinte. 


\begin{tabular}{|c|c|c|}
\hline ENCONTRO & TEMA & MINISTRANTE \\
\hline \multirow[t]{2}{*}{$1^{\circ}$} & $\begin{array}{l}\text { Abertura } \\
\text { - esclarecimentos } \\
\text { - perfil do professor }\end{array}$ & $\begin{array}{l}\text { Prof }{ }^{\text {a }} \text { Nilva Campina e } \text { Mônica } \\
\text { Lobarinhas - LPAE/FMUSP }\end{array}$ \\
\hline & $\begin{array}{l}\text { Possibilidades de projetos na } \\
\text { escola }\end{array}$ & 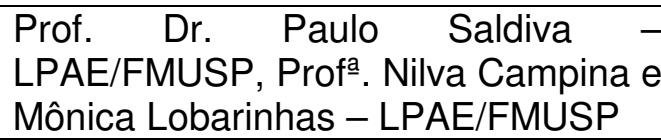 \\
\hline $2^{0}$ & Metodologia de Projetos & $\begin{array}{lll}\text { Prof }^{\mathrm{a}} . \mathrm{Dr}^{\mathrm{a}}{ }^{\mathrm{a}} & \text { Martha } & \text { Marandino } \\
\text { FEUSP } & \end{array}$ \\
\hline \multirow[t]{2}{*}{$3^{\circ}$} & Epidemiologia Ambiental & $\begin{array}{l}\text { Prof.Dr. Alfésio } \text { Braga }- \text { LPAE/ } \\
\text { FMUSP }\end{array}$ \\
\hline & Apresentação do LPAE & Prof ${ }^{a}$. Débora Lobo - LPAE/FMUSP \\
\hline \multirow[t]{2}{*}{$4^{\circ}$} & $\begin{array}{l}\text { Reprodução, Gestação e } \\
\text { Poluição }\end{array}$ & $\begin{array}{l}\text { Prof. Dr. Luiz Alberto } \\
\text { LPAE/FMUSP }\end{array}$ \\
\hline & Geografia Ambiental & Prof ${ }^{a}$. Dr ${ }^{a}$. Helena Ribeiro - FSPUSP ${ }^{X}$ \\
\hline \multirow[b]{2}{*}{$5^{\circ}$} & Biomonitoramento de Ozônio & Prof ${ }^{a}$.Dr ${ }^{\mathrm{a}}$. Marisa Domingos - $\mid \mathrm{Bt}^{\mathrm{XI}}$ \\
\hline & Avaliacão parcial & \\
\hline $6^{\circ}$ & Elaboração de projetos & $\begin{array}{l}\text { Prof. Dr. Luiz Alberto Pereira, Prof }{ }^{a} \text {. } \\
\text { Nilva Campina e Mônica Lobarinhas } \\
\text { LPAE/FMUSP }\end{array}$ \\
\hline $7^{0}$ & Bioensaio com Tradescantia & $\begin{array}{lcll}\text { Prof }^{\mathrm{a}} . & \text { Dr }^{\mathrm{a}} . & \text { Eliane } & \text { Tigre } \\
\text { LPAE/FMUSP }\end{array}$ \\
\hline $8^{0}$ & $\begin{array}{l}\text { Ida ao LPAE } \\
\text { * Efeito Tóxico do } \mathrm{PM}_{10} \text { no } \\
\text { desenvolvimento embrionário } \\
\text { do Gallus domesticus. } \\
\text { * instalações do LPAE }\end{array}$ & $\begin{array}{l}\text { Prof }^{\mathrm{a}} \text {. Dra }{ }^{\mathrm{a}} \text { Heloísa Guimarães } \\
\text { LPAE/FMUSP e Prof } \\
\text { Tigre - Dr - DPAE/FMUSP }\end{array}$ \\
\hline $9^{\circ}$ & Organização dos projetos & $\begin{array}{l}\text { Prof }{ }^{a} \text {. Mônica Lobarinhas e Nilva } \\
\text { Campina - LPAE/FMUSP }\end{array}$ \\
\hline \multirow[b]{2}{*}{$10^{\circ}$} & $\begin{array}{l}\text { Planejamento de Projetos e } \\
\text { simulação na escola }\end{array}$ & $\begin{array}{ccc}\text { Prof. Dr. } & \text { Paulo } & \text { Saldiva } \\
\text { LPAE/FMUSP } & & \\
\end{array}$ \\
\hline & Avaliação final & \\
\hline
\end{tabular}

A maioria dos ministrantes convidados é pesquisador no LPAE - Prof. Dr. Alfésio Luis Ferreira Braga, Prof. Dr. Luiz Alberto Amador Pereira, Prof ${ }^{a}$. Drª . Eliane Tigre Guimarães Sant'Anna, Profạ. Débora-Jã de Araújo Lobo,

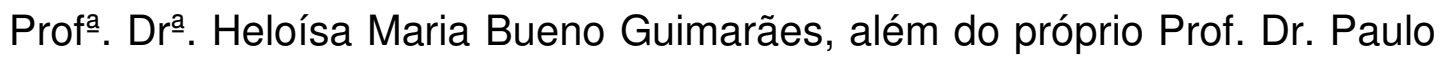
Saldiva. Ainda estiveram presentes, com o objetivo de oferecer um melhor

\footnotetext{
${ }^{\text {IX }}$ Faculdade de Educação da Universidade de São Paulo

X Faculdade de Saúde Pública da Universidade de São Paulo

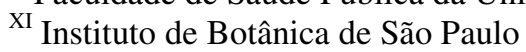


suporte teórico que auxiliassem na realização da proposta, as Prof ${ }^{a}$. Drª . Martha Marandino e Helena Ribeiro. A primeira, do Departamento de Metodologia do Ensino e Educação Comparada da FEUSP e a segunda, professora titular do Departamento de Saúde Ambiental da FSPUSP, que contribuíram dando noções sobre metodologia e elaboração de projetos e geografia ambiental, respectivamente.

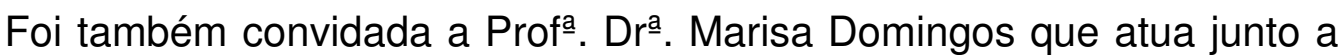
Seção de Ecologia do IBt (Instituto de Botânica de São Paulo) na Divisão do Jardim Botânico de São Paulo e desenvolve alguns projetos de pesquisa em parceria com o LPAE.

Uma das principais características deste curso foi a preocupação com a sua continuidade. Para tanto, no penúltimo encontro foram elaboradas discussões que estimulassem os professores a escreverem seus préprojetos de forma a organizá-los e debatê-los com Dr. Saldiva no encontro seguinte.

No último encontro, o Dr. Saldiva pôde, a partir dos pré-projetos apresentados, discutir sobre a factibilidade de cada um, dar sugestões e avaliar as necessidades pertinentes. Todos os projetos foram considerados viáveis, sendo que o Dr. Saldiva recomendou vários acréscimos às atividades planejadas, comprometendo-se, em nome do LPAE, a subsidiar os professores, oferecendo tanto respaldo técnico como de material necessário. 
No segundo momento deste encontro, os professores redigiram seus projetos, já com as alterações indicadas pelo Dr. Saldiva (anexo D) e elaboraram uma relação de suas necessidades para que estes pudessem ser colocados em prática.

Foi, ainda, aventada uma proposta de supervisão por parte do LPAE e através desta autora, a partir do início do ano letivo de 2006, com o propósito de acompanhar os professores na elaboração e implantação de seus projetos nas escolas, auxiliando-os no desenvolvimento e execução das atividades planejadas. Ficaram acordados encontros individuais conforme as necessidades em cada escola e oito reuniões, com todo o grupo, a serem realizadas mensalmente durante o ano de 2006.

O curso foi avaliado pelos professores em dois momentos: no $5^{\circ}$ encontro (Anexo E2) e no último (Anexo E3). .

\subsection{2. 2. Supervisão e Acompanhamento}

Em 2006, devido à necessidade de afastamento desta autora entre março e setembro deste ano para tratamento de saúde, não foi possível a realização das supervisões periódicas, conforme proposto no final do curso. Porém, neste ano, obteve-se algum avanço quando, em outubro, foi realizada a primeira reunião de supervisão e estava presente o coordenador da pesquisa "Estudo Epidemiológico na População Residente na Baixada Santista - Estuário de Santos: Avaliação de Indicadores de Efeito e de Exposição a Contaminantes Ambientais"XII (EEPRBS - Estuário). Este estudo é uma parceria entre a Universidade Católica de Santos (UNISANTOS), o

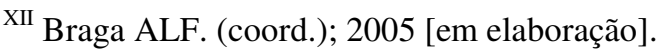


LPAE, a Universidade de Santo Amaro (UNISA), o Centro de Estudos de Cultura Contemporânea (CEDEC) e o Instituo de Biofísica Carlos Chagas Filho da Universidade Federal do Rio de Janeiro (UFRJ). Tem apoio financeiro do Conselho Nacional de Desenvolvimento Científico e Tecnológico (CNPq).

Esta pesquisa, que se iniciou no ano de 2005 e tem previsão de término em 2008 apresenta como principal objetivo estimar os efeitos à saúde associados à exposição aos contaminantes ambientais entre os moradores da Baixada Santista - Estuário de Santos e São Vicente e georreferenciá-los.

Este encontro aconteceu no Centro de Capacitação e Pesquisa em Meio Ambiente (CEPEMA) de Cubatão e, além de professores participantes do curso, também estava presente um representante da SEDUC - Cubatão. Após uma conversa preliminar onde se confirmou a não continuidade dos projetos até aquele momento, foi apresentada a pesquisa EEPRBS Estuário, já explicitada acima e feito o convite aos professores, juntamente com seus alunos, a dela participarem. Após algumas discussões sobre as possibilidades de inserção dos alunos em diversos momentos e atividades da pesquisa, alguns professores interessaram-se pela proposta, pretendendo envolver alunos tanto dos cursos técnicos nos quais lecionam, como do Ensino Médio ou mesmo, como no caso das duas professoras que são responsáveis pelo Núcleo de Educação Ambiental de Cubatão (NEA), intentando que seus alunos estagiários dos cursos de Educação Ambiental oferecidos pelo NEA pudessem fazer parte do estudo. 
Foram, então, agendados dois encontros, um em Cubatão outro em São Vicente, nos quais os professores comprometeram-se a levar os estudantes interessados em participar.

No encontro seguinte, ocorrido 09 dias depois no Centro Cultural de Cubatão, local cedido pela SEDUC - Cubatão, estavam presentes, além do representante da SEDUC - Cubatão, professores e estudantes entre alunos do Ensino Médio, dos cursos técnicos e estagiários do NEA.

Devido à distância e conseqüente dificuldade de transporte de alunos de uma escola em São Vicente/SP, município da Baixada Santista onde lecionava uma professora com interesse em incluir seus alunos na pesquisa EEPRBS - Estuário, em novembro, dois pesquisadores foram até a EE Parque das Bandeiras - Gleba II para apresentação da referida pesquisa.

Em ambos os encontros foi apresentado o estudo EEPRBS - Estuário e discutidas as possibilidades de participação dos alunos, bem como suas disponibilidades de horários. Ficou acordado que seria conferido certificado de participação a todos podendo, estas horas de trabalho na pesquisa, serem consideradas como horas de estágio aos alunos dos cursos técnicos em Meio Ambiente bem como aos do NEA.

Em janeiro de 2007 iniciaram-se reuniões para capacitação dos interessados em aplicar a pesquisa, momento em que alunos da EE José da Costa participantes do Projeto Coração Roxo inseriram-se nas atividades. 
Nestes encontros, foram discutidas técnicas de aplicação do questionário, uso do Palm-Top, rotina e possíveis problemas de pesquisa em campo além de possibilidades de datas, horários e formas de locomoção.

Em março de 2007 repetiu-se o procedimento de ida a uma escola (EM Primeiro de Maio), onde lecionava um professor participante do curso. Desta vez, na cidade de Guarujá/SP, a apresentação da pesquisa EEPRBS Estuário foi feita a alunos do curso técnico em meio ambiente, que acontece no período noturno. Devido ao grande número de alunos interessados, dividiu-se a turma em grupos menores para que pudessem ser realizadas capacitações com melhor aproveitamento. Estas aconteceram na própria escola.

\subsection{3. Projeto Biomonitoramento e Promoção da Saúde}

Em 2005, a professora de ensino básico Ana Lúcia Mello tem seu projeto de pesquisa aprovado pelo Departamento de Patologia para desenvolvimento de sua tese de doutorado junto ao LPAE.

A proposta deste estudo é verificar, a partir de 2008, se a Promoção da Saúde baseada em metodologias participativas com a utilização de bioindicadores permite que alunos do Ensino Médio da rede pública de ensino do município de Guarujá/SP percebam os agravos aos quais sua saúde está exposta.

Visto que em junho de 2007 este projeto não havia iniciado suas atividades práticas, não o consideraremos para efeito de resultados, discussão e conclusão neste trabalho. 


\subsubsection{Comunicação para além da academia: diferentes possibilidades}

Efetuada basicamente através da mídia ${ }^{\mathrm{XIII}}$ a comunicação entre $\mathrm{O}$ LPAE e a população fora da área científica tem acontecido, na maioria das vezes, por meio de entrevistas ou reportagens motivadas por assuntos que possam parecer interessantes ao grande público no entender de quem propõe a entrevista ou realiza a reportagem.

Segundo Moraes $^{9}$, em vista da abrangência crescente que a mídia alcançou nas últimas décadas, pode ser considerada como umas das vertentes responsáveis pela construção dos valores sociais e dos conhecimentos, tanto individuais como coletivos. Porém, é importante levarmos em conta o fato de essa comunicação, em grande parte das vezes, se dar de forma concisa, com poucas possibilidades de aprofundamento e continuidade, característica que é própria da maioria dos veículos de comunicação atuais direcionados ao grande público, como a televisão e o rádio.

Outra forma de alcançar a população não acadêmica e que vem desencadeando algumas ações do LPAE neste sentido, especialmente a partir de 2001, é através de escolas de Ensino Básico, com foco específico nas questões que envolvem Educação Ambiental.

\footnotetext{
XIII A aclimatação do termo mídia no Brasil não tem se dado sem ambigüidades. Recentemente a palavra mídia, sem s, antecedida do artigo feminino (a mídia), fixou-se mais dominantemente e é empregada, quer no sentido estrito do jornalismo impresso, quer no sentido de meios noticiosos e informativos em geral, incluindo o rádio e a televisão. (Santaella,2000:24.)
} 
A legislação brasileira define Educação Ambiental como:

(...) processos por meio dos quais o indivíduo e a coletividade constroem valores sociais, conhecimentos, habilidades, atitudes e competências voltadas para a conservação do meio ambiente, bem de uso comum do povo, essencial à sadia qualidade de vida e sua sustentabilidade. (Art. 1ํ da Lei no. 9.795 de abril de 1999) ${ }^{10}$

Para que se alcance, de fato, a Educação Ambiental em seu sentido completo, incluindo-se aí a construção de "habilidades, atitudes e competências voltadas para a conservação do meio ambiente"10, faz-se necessária a educação escolar sistemática, há muito reconhecida como de importância basilar para as questões ambientais.

Ao observarmos algumas características do ensino de hoje no Brasil, percebemos que as escolas de Ensino Fundamental e Médio apresentam-se como caminho bastante interessante para institutos de pesquisa que trabalhem na área ambiental e almejem aumentar a proximidade com a comunidade não acadêmica. A necessidade dos sistemas de ensino em trabalharem Educação Ambiental, a possibilidade de discussões sólidas e sistemáticas, além da perspectiva de alcançar um número significativo e constante de pessoas em plena formação, fazem da escola um local atraente e promissor para o propósito da divulgação científica, especialmente dentro desta área do conhecimento.

Para Figueiredo"11 "o domínio da informação está diretamente ligado ao poder de interferir e reorientar as relações humanas e da sociedade com a natureza”. 
Em se tratando de um laboratório de pesquisa que trabalha de forma bastante consistente com assuntos ligados à temática ambiental, quando nos referimos à divulgação científica e seus propósitos, estamos considerando a hipótese de esta divulgação vir a ser uma das muitas possibilidades de Educação Ambiental.

Naturalmente a mídia, da forma como a concebemos hoje, com seus variados recursos de alcance às regiões mais remotas, representa um importante papel para a divulgação da ciência. Porém, pelas características específicas de cada uma, mídia e instituições de ensino podem vir a ser entendidas como meios complementares de possibilidades de aproximação com o público não acadêmico. Enquanto a mídia é capaz de uma inserção ampla e, na maior parte das ocasiões, trata os assuntos de forma breve e mais superficial, a escola, por sua vez, limita-se a um número restrito de pessoas, porém com abordagens constantes e aprofundadas.

Após o exposto acima não poderíamos deixar de levantar uma questão que surge quase como conseqüência direta quando um centro de pesquisa se propõe a expandir e divulgar seus trabalhos em instituições de ensino básico que fogem ao seu limite de ação: seria possível um laboratório de pesquisas universitário, com suas características essencialmente acadêmicas, com seu vocabulário de alto nível técnico, alcançar diretamente alunos em processo de escolarização? 


\section{1. 5. O LPAE e a transmissão do conhecimento: sobre a} socialização do saber

A preocupação com a transmissão das mensagens científicas é recorrente em estudiosos da educação já há muito, mas é em meados de 1980 que estas discussões ganham corpo entre os educadores.

É a partir dessa preocupação que surgem alguns trabalhos que estudam a transmissão do conhecimento científico a crianças e adolescentes em processo de escolarização. Destes estudos surgem alguns conceitos, entre eles o de transposição didática, que segundo Chevallard ${ }^{12}$ significa a transposição do saber gerado pelas pesquisas científicas, de tal forma adequados, que se tornam capazes de serem compreendidos e assimilados por alunos das redes básicas de ensino.

Aprofundaremos o conceito de transposição didática no Capítulo 3, onde discutiremos as idéias de diferentes autores, porém é importante salientar que partimos do pressuposto, de acordo com estudos anteriores como os realizados por Chevallard ${ }^{12}$, Perrenoud ${ }^{13}$ e Marandino $^{14}$, que os resultados dos trabalhos do LPAE podem vir a ser compreendidos por crianças e adolescentes, desde que feita a devida transposição didática. Essa idéia embasa toda a discussão que faremos ao longo deste trabalho em relação à inserção do LPAE em escolas. 


\section{2. Estruturação do estudo}

A estruturação deste estudo deu-se a partir da análise das comunicações efetuadas pelo LPAE com o público não acadêmico.

Consideramos importante ressaltar duas questões empíricas que permearam esta investigação: a de que o LPAE teria uma boa inserção na mídia não acadêmica e, indo além, que sua equipe de cientistas não só acreditaria neste fato como também entenderia que entre os objetivos do Laboratório como instituição de pesquisa deveriam estar propostas mais arrojadas de Educação Ambiental. Além disso, uma idéia que se fazia pouco clara dizia respeito à questão de que, em se confirmando a vontade da equipe - ou de parte dela - em expandir a abrangência de divulgação de seus trabalhos, quais razões haveriam para isto?

Em referência à primeira colocação, acreditamos que dispense excessivos esclarecimentos, uma vez que esta pesquisa propõe-se a avaliar se esta informação, recorrente a quem se dispusesse transitar um pouco pelas dependências do LPAE e ouvir seus pesquisadores, é fato ou apenas faz parte do imaginário deste grupo.

Quanto à colocação de que seria de interesse da equipe como um todo levar seus trabalhos para o público escolar, apesar de acreditarmos, como pesquisadora que somos, de que a divulgação científica deva ser um compromisso a ser assumido por todos envolvidos nesta área, entendemos que sempre existe a possibilidade de opiniões discordantes. Este fato não poderia deixar de ser considerado para qualquer grupo, mas ainda torna-se 
mais plausível quando lidamos com uma equipe numerosa, como no caso do LPAE, onde cerca de 80 pessoas desenvolvem suas pesquisas. Todas com sólida formação acadêmica e muitas delas trabalhando com a chamada pesquisa pura, ou seja, pesquisas que não tem utilidade prática imediata, mas servem de embasamento para outros estudos. Como algumas das ações que serão aqui avaliadas dizem respeito a realizações de atividades desenvolvidas pelo LPAE a partir de propostas de Educação Ambiental com Ensino Básico, entendemos que, caso uma parcela significativa da equipe discorde deste propósito, sejam por quais motivos forem, este fato pode vir a interferir nestas ações, tornando-as mais dificultosas ou até mesmo inviabilizando-as. 


\section{CAPÍTULO 2: OBJETIVOS}

Sempre que o homem aplique a veemência $e$ perseverante energia de sua alma a um fim, ele vencerá os obstáculos, e se não atingir o alvo, fará pelo menos coisas admiráveis.

José de Alencar ${ }^{X I V}$

O enfoque desse estudo será na busca por analisar as comunicações realizadas pelo LPAE com a população não acadêmica e contribuir para o aprimoramento na qualidade da Comunicação Pública da Ciência.

Têm-se como objetivo geral da pesquisa:

- analisar as possibilidades e limites de atuação de um Laboratório de produção científica do porte do LPAE em Comunicação Pública da Ciência.

Dentro deste objetivo maior, pode-se incluir como o que, mais especificamente, almeja-se:

- avaliar o alcance que o LPAE vem obtendo no período de sua formação à junho de 2007 junto ao público não acadêmico;

- analisar as formas de Comunicação Pública da Ciência realizadas pelo LPAE:

- através dos diferentes tipos de mídia;

XIV Alencar J. A pata da gazela. Rio de Janeiro: Ed. José Aguilar Ltda, 1959, vol. 1. 
- através das escolas públicas de Ensino Básico;

- analisar as principais questões que permeiam as relações entre cientistas ligados à área da saúde e profissionais da mídia não acadêmica; 


\title{
CAPÍTULO 3: REFERENCIAL TEÓRICO
}

\author{
"Porque quando vi dar entendimento \\ Às cousas que o não tinham, o temor \\ Me fez cuidar que efeito em mim faria. \\ Conheci-me não ter conhecimento." \\ Luís de Camões ${ }^{X V}$
}

Diferentes referenciais teóricos embasaram esta pesquisa. Neste capítulo, apresentaremos os autores e suas idéias que nos subsidiaram em relação à pesquisa qualitativa, Comunicação Pública da Ciência, Educação Ambiental e transposição didática.

\section{1. Pesquisa qualitativa}

Nossa proposta é apresentar aspectos da pesquisa qualitativa de maneira que se possa perceber as articulações desta com 0 presente estudo. Para tanto, avaliamos ser necessário contextualizá-la historicamente para melhor compreendê-la nos moldes como a entendemos hoje. Naturalmente, não temos a pretensão de desenvolver um estudo aprofundado ou polemizar as discussões sobre as diferentes correntes de pesquisas utilizadas atualmente, mas sim traçar um perfil da pesquisa qualitativa sob a ótica de diversos e conceituados teóricos da área e mostrar de forma clara a inserção desta neste trabalho.

XV Versos e Alguma Prosa de Luís de Camões. 757ª ed. Lisboa: Moraes Editores; 1977. 


\section{1. 1. Breve histórico}

É no final do século XIX que se inicia a abordagem qualitativa de pesquisa, período em que alguns cientistas ligados às áreas sociais começam a questionar o modelo amplamente utilizado nas investigações das áreas das ciências físicas e naturais ${ }^{15}$. Este modelo, denominado de experimental (ou científico), apoiava-se nos postulados do positivismo, sistema criado por Auguste Comte no século XIX cujas raízes remontam ao empiricismo da antiguidade, e que avança pelo século $X X$ com a denominação de neopositivismo, abarcando diferentes correntes ${ }^{16}$.

Antonio Chizzotti ${ }^{17}$ faz uma comparação entre o desenvolvimento da pesquisa qualitativa com o método cientifico experimental, que surgiu a partir de uma necessidade - a de se fazer um contraponto aos conhecimentos especulativos, intuitivos e de senso comum, comprovando os conhecimentos construídos de forma coerente e rigorosa. Para este autor, da mesma forma, na segunda metade do século XIX com a crescente expansão das investigações em ciências humanas e sociais, se começa a perceber a necessidade de se ampliar o campo, as técnicas e os instrumentos de pesquisas nestas áreas. Paralelamente, o desenvolvimento da física e da matemática "puseram em crise o edifício de certezas seguras do cientificismo, questionaram a infalibilidade das ciências, demonstraram a inviabilidade de previsões absolutas (...)",17.

Ludke e André ${ }^{15}$, importantes teóricas brasileiras nesta área, ao discutirem os fundamentos da abordagem qualitativa, apontam Dilthey, no final do século XIX, como um dos pioneiros na busca por uma metodologia 
diferenciada para as ciências sociais. Segundo estas autoras, Dilthey tinha entre seus principais argumentos a idéia de que o estabelecimento de leis gerais, consideradas como possíveis para áreas de conhecimento como a física e a biologia, não eram viáveis para os estudos de fenômenos humanos e sociais, extremamente complexos e dinâmicos. Este historiador também defendia que, no caso específico do estudo da história, o foco de interesse centra-se na compreensão de um evento em particular e não em sua explicação causal e que um dos elementos fundamentais para sua compreensão é o contexto único em que o fato ocorre. Dilthey sugere, então, que se utilize a hermenêutica como abordagem metodológica nas pesquisas de cunho social, uma vez que a preocupação principal está na interpretação dos significados, nas mensagens e nas suas inter-relações.

Além de Dilthey, Weber é outro nome que merece ser mencionado como um importante colaborador na conformação do desenho da perspectiva qualitativa de pesquisa por ter destacado o principal diferencial entre a ciência social e a física - a compreensão (verstehen) como o objetivo, centrada nos significados atribuídos pelos sujeitos às suas ações, significados estes que só poderão ser entendidos quando contextualizados. A perspectiva de conhecimento idealista-subjetivista começa, então, a ser defendida por diferentes estudiosos que, influenciados pelas idéias de Weber e Dilthey, acreditam que deva ser valorizada a maneira individualizada de entendimento que cada sujeito dá à realidade e que esta não pode ser considerada como algo externo aos indivíduos. Passam, também, a criticar a posição positivista de ciência ao buscarem a 
“interpretação no lugar da mensuração, a descoberta em lugar da constatação" ao valorizarem a indução e ao assumirem "que fatos e valores estão intimamente relacionados, tornando-se inaceitável uma pesquisa neutra do pesquisador" ${ }^{15}$.

Não é objetivo deste trabalho analisar em profundidade as raízes históricas da pesquisa qualitativa mas entendemos que, para melhor contextualizá-la no estudo aqui realizado, é importante ressaltar as correntes das quais se deriva a abordagem qualitativa de pesquisa, elencadas por Ludke e André ${ }^{15}$ e que apresentamos resumidamente a seguir:

A fenomenologia enfatiza os aspectos subjetivos do comportamento humano e preconiza que é preciso penetrar no universo conceitual dos sujeitos para poder entender como e que tipo de sentido eles dão aos acontecimentos e às interações sociais que ocorrem em sua vida diária (...);

$O$ interacionismo simbólico assume como pressuposto que a experiência humana é mediada pela interpretação, a qual não se dá de forma autônoma mas à medida que o indivíduo interage com o outro. É por meio das interações sociais (...) que vão sendo construídas (...) as suas visões de realidade.(...);

A etnometodologia (...) o estudo de como os indivíduos compreendem e estruturam o seu dia-a-dia, isto é, procura descobrir "os métodos" que as pessoas usam no seu dia-a-dia para compreender e construir a realidade que as cerca.(...);

A etnografia, cuja principal preocupação é com o significado que tem as ações e os eventos para as pessoas ou os grupos estudados (...) é a tentativa de descrição da cultura.

Em síntese, é esse o pano de fundo no qual vai se amoldando uma nova abordagem de pesquisa, que passa a ser denominada de qualitativa, 
por se opor à linha quantitativista (que mensura as unidades da realidade de forma compartimentada).

Outra designação que esta abordagem recebe por alguns autores é de pesquisa naturalística, por estudar os fenômenos em sua forma natural, sem manipulação das variáveis ou tratamento experimental ${ }^{15}$. Questiona-se, principalmente nas áreas humanas e sociais, a forma de condução das pesquisas positivistas "que privilegiavam a busca da estabilidade constante dos fenômenos humanos, a estrutura fixa das relações e a ordem permanente dos vínculos sociais"17 sendo a pesquisa qualitativa apresentada como contraponto: "essas novas pesquisas (as qualitativas) valorizaram os aspectos qualitativos dos fenômenos, expuseram a complexidade da vida humana e evidenciaram significados ignorados da vida social" 17 .

É dentro das idéias deste conceito, no sentido de ter-se o olhar sobre o todo, considerando sempre as interações e influências recíprocas exercidas pelos sujeitos, que este estudo encontra suas bases metodológicas. Trataremos dessa questão mais adiante, mas de momento ressaltamos que a inserção deste trabalho nas propostas qualitativas de pesquisa encontra respaldo já nesta fase das discussões deste tipo de metodologia.

\section{1.2. Em busca de um paradigma qualitativo}

Conforme vimos acima, essas idéias já estavam presentes entre os pesquisadores do final do século XIX, porém as discussões envolvendo as questões referentes à pesquisa qualitativa ainda eram esparsas e pouco 
disseminadas, só ganhando força a partir de estudos que possibilitariam sua fundamentação algumas décadas depois. Para isso, a chamada "Escola de Frankfurt" teve um papel relevante. O termo pode ser considerado para denominar tanto uma teoria social específica, de cunho marxista, como um grupo de intelectuais filiados ao Instituto de Pesquisas Sociais de Frankfurt que, entre 1930 e o início da década de 40, produziu contribuição das mais significativas para a formulação de uma "teoria crítica da sociedade" ${ }^{18}$.

A equipe da "Escola de Frankfurt" se desfez no começo dos anos de 1940, mas deixou marcas importantes que iriam ser retomadas cerca de 20 anos depois. Neste período os métodos qualitativos passam a ganhar maior popularidade, pois trazem em seu bojo a proposta de retratar diferentes pontos de vista de todos os sujeitos envolvidos, incluindo os daqueles destituídos de qualquer poder. Isto torna esta metodologia de pesquisa consonante com os ideais democráticos dos movimentos sociais e trabalhistas que começavam a despontar na década de 1960 e que reivindicavam, principalmente, igualdade de direitos das minorias ${ }^{15}$.

Esse foi um preparo importante para que, a partir da década de 1970, o chamado paradigma qualitativo passasse a ganhar força. Trabalhos utilizando a abordagem qualitativa começam a ser publicados e diferentes correntes vão surgindo, buscando associar os fundamentos teóricos com os avanços tecnológicos. Apesar de ser um período em que ainda não estavam bem definidos seus fundamentos epistemológicos nem as articulações possíveis com as questões metodológicas, este momento é visto por muitos como um novo espaço que veio a ser preenchido por problemas que não 
poderiam ser estudados dentro dos limites austeros da metodologia estruturada em modelos e procedimentos rígidos do paradigma positivista ${ }^{18}$.

Na década de 80 surge, então, uma série de publicações que vão tentar completar a lacuna contida no paradigma qualitativo, tratando tanto dos procedimentos metodológicos como dos fundamentos teóricos. Porém, apesar de, neste período, encontrarmos um número de publicações consideravelmente grande, a caracterização de pesquisa qualitativa ainda parece um tanto confusa, sendo o eixo norteador comum a todos a oposição ao positivismo. Entretanto, a própria visão que muitos pesquisadores, neste momento, tem do positivismo ao qual se opõem, parece um tanto ingênua: "(o positivismo) vê o conhecimento científico como uma fotografia do real, objetiva e neutra, e que corresponde ao único conhecimento infalível e verdadeiro."18, sendo que podem ser encontrados trabalhos auto-definidos como qualitativos apenas por não fazerem uso de dados numéricos ou simplesmente por utilizarem-se de técnicas de coleta - como por exemplo, a observação - tidas como qualitativa ${ }^{15}$.

Alves-Mazzotti e Gewandsznajder ${ }^{18}$ ao avaliarem o panorama atual em que se encontra a pesquisa qualitativa, citam algumas teóricas importantes nesta área como Catherine Marshall, Evelyn Jacob e Yvonna Lincoln que se mostravam preocupadas com as muitas e diferentes formas de investigação que se auto intitulavam qualitativas. Em 1989 é realizada em São Francisco (Estados Unidos das Américas - EUA) a "Conferência dos Paradigmas 
Alternativos" cujo objetivo basilar, segundo Egon Guba ${ }^{\mathrm{XVI}}$ apud AlvesMazzotti e Gewandsznajder ${ }^{18}$, foi o de trazer legitimidade a alternativas não hegemônicas e, como principal resultado apresentou três paradigmas considerados como sucessores do positivismo - o construtivismo social, o pós-positivismo e a teoria crítica. Não detalharemos estas questões por não consideramos necessário este tipo de aprofundamento neste trabalho. Analisaremos os encaminhamentos dados às abordagens qualitativas nos momentos mais recentes.

\subsection{Cenário atual}

Tendo sido dada acima uma rápida noção dos principais elementos que compuseram o pano fundo no qual foi tecida a pesquisa qualitativa, buscaremos dar uma idéia do panorama atual em que se encontram as discussões nesta área.

Após a "cruzada" travada entre os defensores das pesquisas qualitativas e os das quantitativas, as últimas duas décadas tem sido marcadas pela procura de novas alternativas, menos dominadas pelos discursos contra positivistas e mais adequadas às necessidades de pesquisadores que atuam em diferentes campos. Apesar do avanço considerável destas discussões, o cenário atual ainda se apresenta um tanto confuso e bastante intricado.

Muita confusão metodológica e muitas afirmações falsas surgem da compreensão equivocada ao se fazer a distinção entre qualitativo e quantitativo na coleta e análise de dados, com princípios do delineamento da pesquisa e interesses do

${ }^{\mathrm{XVI}}$ The paradigm dialog. Califórnia: Sage Publications; 1990. 
conhecimento. É muito possível conceber um delineamento experimental, empregando entrevistas em profundidade para conseguir os dados. Do mesmo modo, um delineamento de estudo de caso pode incorporar um questionário de pesquisa para levantamento, junto com técnicas observacionais $(\ldots)^{19}$.

Atualmente, considerar a agregação pura e simples da pesquisa qualitativa ao positivismo é vista como uma opinião reducionista, pois após anos de discussões, já se começa a clarear a idéia que qualidade e quantidade estão profundamente associadas.

Gamboa $^{20}$, ao analisar o falso dualismo entre estes dois elementos, por ele denominado de categorias quantidade-qualidade, nos diz o seguinte:

Essas categorias modificam-se, complementam-se e transformam-se uma na outra e vice-versa, quando aplicadas a um mesmo fenômeno. De fato, as duas dimensões não se opõem, mas se inter-relacionam como duas fases do real num movimento cumulativo e transformador, de tal maneira que não podemos concebê-las uma sem a outra, nem uma separada da outra.

\subsection{Conceituações atuais da pesquisa qualitativa}

Desde a década de 1990 mantêm-se a controvérsia da possibilidade de coexistência ou não dos diferentes paradigmas, consideradas por uns como uma possibilidade de acomodação e por outros como insustentável.

Buscar uma definição única para pesquisa qualitativa mostrou-se-nos tarefa insana. Pareceu-nos mais coerente apresentar as propostas de definição feitas por alguns estudiosos importantes da atualidade para que, dessa forma, pudéssemos ter uma noção clara de como está sendo 
entendido este tipo de pesquisa nesta última década e analisar os pontos considerados comuns a estes autores. Assim, vejamos o que nos dizem os importantes teóricos consultados neste estudo:

A abordagem qualitativa parte do fundamento de que há uma relação dinâmica entre o mundo real e o sujeito, uma interdependência viva entre o sujeito e o objeto, um vínculo indissociável entre o mundo objetivo e a subjetividade do sujeito (...) o sujeito-observador é parte integrante do processo de conhecimento e interpreta os fenômenos, atribuindo-lhes um significado ${ }^{17}$.

(...) a principal característica das pesquisas qualitativas é o fato que essas seguem a característica "compreensiva" ou interpretativa. Isto significa que essas pesquisas partem do pressuposto de que as pessoas agem em função de suas crenças, percepções, sentimentos e valores e que seu comportamento tem sempre um sentido, um significado que não se dá a conhecer de modo imediato, precisando ser desvelado ${ }^{18}$.

$\mathrm{Na}$ pesquisa qualitativa o pesquisador procura reduzir a distância entre a teoria e os dados, entre contexto e ação, usando a lógica da análise fenomenológica, isto é, da compreensão dos fenômenos pela sua descrição e interpretação ${ }^{21}$.

(...) a pesquisa qualitativa evita números, lida com interpretações das realidades sociais e é considerada pesquisa soft. ${ }^{19}$.

Mesmo que ainda não haja concordância plena entre alguns autores sobre uma conceituação categórica e única de pesquisa qualitativa, as discussões parecem apontar para algumas definições, em especial quanto ao que não se deve esperar deste tipo de pesquisa. Bauer e Gaskell ${ }^{19}$ resumem bem esta idéia ao ressaltarem que não se pode pretender que a pesquisa qualitativa possua o monopólio da interpretação, assim como a 
quantitativa não chega às suas conclusões de imediato, apenas com a apresentação de dados numéricos. Estes autores também apontam como uma das conquistas da abordagem qualitativa a desmistificação da "sofisticação estatística como único caminho para se conseguir resultados significativos" 19 .

Após o exposto acima, entendemos ter auxiliado a clarear a opção aqui feita por uma abordagem qualitativa de pesquisa. Deve-se, principalmente, às características dos questionamentos propostos neste estudo, uma vez que a pesquisa qualitativa tem no papel do(s) pesquisador(es) o seu grande diferencial, já que compete a este(s) não apenas descrever, mas sobretudo interpretar os fenômenos observados, atribuindo-lhes significação. Desta forma, o presente trabalho identifica-se em especial com alguns pressupostos deste tipo de análise, como a expressa por Chizzotti ${ }^{17}$ de que "o objeto não é um dado inerte e neutro; está possuído de significados e relações que sujeitos concretos criam em suas ações". Buscou-se, assim, ir além da coleta e análise de dados, procurando-se captar as relações, dinâmicas e complexas, na qual estão inseridos os processos de comunicação do LPAE com o público não acadêmico.

\section{2. Comunicação de massa e Comunicação Pública da Ciência}

Comunicação de massa, segundo Abraham Moles $^{22}$ deve ser entendida como "aquele tipo de comunicação que ocorre entre um emissor e uma multiplicidade de receptores espalhados através de um campo geográfico e social", e incorre em alguns aspectos que não podem ser desconsiderados. 
A idéia de que o próprio cientista deva responsabilizar-se pela divulgação da ciência é controvertida e, em se tratando de comunicação de massas, o jornalismo científico vem florescendo com grande sucesso.

Massarani e Moreira ${ }^{23}$, importantes teóricos na área de divulgação científica, ao discutirem as questões que envolvem a transmissão da informação científica, apontam que esta, quando ocorre "entre os pares é feita por meio da língua e de símbolos e imagens especialmente construídos para tal fim, utilizando estilos e argumentos que variam historicamente". No entanto, segundo estes autores, os textos exibem diferenças importantes em relação aos elaborados originalmente pelos cientistas quando são destinados à divulgação científica.

Uma consideração importante a ser feita, é a contextualização da posição do intermediador, o jornalista responsável por levar esta informação adiante ou a conduzir o programa onde se realiza a entrevista. Não podendo ser absolutamente neutro, uma vez que representa, naquele momento, o meio de comunicação ao qual está a serviço, busca "a" informação, aquela que melhor possa satisfazer os interesses - sejam ideológicos, políticos, religiosos ou meramente comerciais - que moveram a procura pelo assunto a ser veiculado, destacando e enfatizando os tópicos que lhe parecerem mais oportunos. Imaginando-se aqui um profissional que realiza seu trabalho pautado pela ética, naturalmente não se espera que falte com a verdade, ao contrário, sendo minimamente competente, saberá filtrar as informações que possam ser de maior interesse entre todas as apresentadas. Além disso, há que se considerar, no sentido inverso, o "olhar" que este jornalista tem sobre 
o seu objeto de trabalho. O jornalismo científico é hoje uma área de especialização dentro do jornalismo, e muito se tem discutido e abordado sobre o assunto. Como complemento ao conjunto de idéias apresentadas acima, torna-se importante destacar algumas considerações. Costa Bueno ${ }^{24}$, conceituado jornalista e pesquisador, em artigo publicado no sítio Portal do Jornalismo Científico intitulado "Jornalismo Científico e o Compromisso das Fontes" nos mostra um pouco este assunto sob a ótica dos profissionais que produzem as notícias:

A ciência e a tecnologia, no mundo moderno, constituem-se em mercadorias, produzidas $e$ apropriadas pelos grandes interesses, e as fontes, sejam elas pesquisadores, cientistas ou técnicos, podem estar absolutamente contaminadas por vínculos de toda ordem (...). Muitos jornalistas ignoram que esta relação promíscua entre ciência e poder, ciência e capital é cada vez maior (...). É preciso, pois, enxergar sempre além da notícia e da fonte, buscando fugir da armadilha de tornar-se refém de um especialista, que tem outros compromissos além da ciência e da tecnologia (...). Imaginar-se que a competência técnica ou científica prevaleça, em ambientes onde concorrem interesses comerciais $e$ políticos poderosos, é acreditar em duendes.

Outro aspecto relevante, que precisa ser levado em conta quando se trata de comunicação de massa, é a questão que envolve o modo de transmissão neste tipo de procedimento. O destinatário, ao ser nivelado como um todo, diminui significativamente o controle do emissor em relação à intencionalidade da mensagem, já que os signos e códigos por este utilizados muitas vezes não fazem parte do universo cultural do público receptor ${ }^{25}$, em especial quando se trata do universo de códigos e símbolos tão particulares que fazem parte do vocabulário científico. 
Isso ocorre por que na comunicação pessoa a pessoa, face a face, o emissor e receptor podem ir ajustando, passo a passo, as diferenças de níveis entre os códigos culturais e os repertórios de signos que são ou não compartilhados. Esse ajustamento tende a aumentar o grau de controle sobre a informação que é transmitida no ato comunicativo. O mesmo não ocorre nos processos de comunicação de massa, de modo que muita informação não controlada e não intencionada pode chegar aos receptores à revelia do emissor. ${ }^{25}$

Esta preocupação de Santaella ${ }^{25}$ quanto às diferenças entre códigos culturais e os repertórios de signos que perpassam transmissores e receptores é compartilhada, há muito, por estudiosos das questões de divulgação científica. Já em 1931, Ozório de Almeida ${ }^{26}$, em seu livro "A vulgarização do saber", compara as dificuldades encontradas por aqueles que se propõem à transmissão da linguagem científica para a "massa dos homens de instrução média" ${ }^{26} \mathrm{com}$ as das traduções entre diferentes idiomas:

A passagem de certas expressões, que correspondem à mentalidade profundamente peculiar a um povo, e que representa exatamente o seu modo de sentir, não pode ser feita convenientemente por outras línguas, que se mostram assim deficientes ${ }^{26}$.

Díaz $^{27}$ defende a idéia que nem todas as obras de ciência para não cientistas são totalmente compreensíveis a seus destinatários, apontando como um dos motivos o fato da maioria das idéias oriundas da ciência apresentar alto grau de complexidade, amplitude e profundidade, sendo, muitas delas, contrárias ao senso comum o que

obriga aos especialistas a manejar uma linguagem particular, artificial, muito extensa e precisa, em muitos 
casos quase exclusivamente expressável por símbolos não verbais, que necessitam um longo treinamento para seu manejo ${ }^{27}$.

\section{2. 1. Modelos de Comunicação Pública da Ciência}

"Ciência, um ícone da sociedade moderna". Esta frase, de autoria de Brian Wynne ${ }^{28}$, expressa de forma concisa como o conhecimento científico ainda é visto por muitos na atualidade. Colocada no pedestal das certezas absolutas durante décadas, a ciência parecia estar acima da possibilidade de qualquer questionamento e caminhar paralela à sociedade sem estar, de fato, inserida nela. Esta idéia é compartilhada por importantes teóricos atuais como Nieto ${ }^{29}$, Myers $^{30}$, Lévy-Leblond ${ }^{31}$, além do próprio Wynne ${ }^{28}$.

Como conseqüência dessa visão, o modo de comunicação entre ciência e demais setores da sociedade também foi grandemente influenciado, gerando o que se tornou conhecido como modelo de déficit.

Discutiremos brevemente este e outros modelos propostos nesta última década para a CPC.

\section{2. 2. 1. Modelo de déficit}

Essa abordagem que vem sendo discutida por vários autores como Durant $^{32}$, Myers $^{30}$, Miller ${ }^{33}$, Lewenstein e Brossard ${ }^{34}$, parte do princípio que a comunicação se dá a partir dos cientistas para o público, pressupondo-se que os primeiros sabem - e são capazes de satisfazer - as necessidades dos segundos em relação aos conhecimentos científicos, ou nas palavras de Miller ${ }^{33}$ : 
(...) uma via de mão única na comunicação em que a comunicação flui dos cientistas, no topo, para as massas, em baixo. Muito bem resumido pelo estudioso de retórica Alan Gross ${ }^{X V I I}$, não se trata de um caso de suficiência científica, mas sim de deficiência pública.

Em um período da história em que a sociedade ocidental vem primando por tentar - e nem sempre conseguir - se mostrar através de ideais igualitários e democráticos, esse modelo vem sofrendo sérias críticas nas últimas décadas. Grande parte dos estudiosos atuais considera a preponderância desse padrão nas práticas e nas políticas de comunicação pública da ciência algo que necessitava - e, em alguns casos, necessita ser modificado por tratar-se de um processo de comunicação que ocorria e ocorre centrado na informação e na produção/produtor do conhecimento e não na interlocução entre cientistas e não cientistas. Alguns autores chegam mesmo a serem sarcásticos quando se referem a este modelo de comunicação, como Ziman ${ }^{X V I I I}$ apud Lewenstein e Brossard ${ }^{34}$

Esta medida se tornou conhecida como modelo de déficit, desde que se delineou o déficit de conhecimento do público que deve ser preenchido, com a presunção de que após fixar o déficit, tudo vai melhorar (o que quer que isso significasse).

Ou Miller ${ }^{33}$ :

A idéia era de que o público envolvido nesse processo era uma massa, em geral sem nada na cabeça, passiva, refém de desinformações fornecidas por charlatães auxiliados e favorecidos pela mídia.

\footnotetext{
${ }^{\mathrm{XVII}}$ Gross AG. The Role of Rhetoric in the Public Understanding of Science. Public Understanding of Science, n.3, 1994, p. 3-23.

XVIII Ziman, J. Public Understand of Science. Science, Technology \& Human Values. 16 (1). Winter, 1991. p. 99-105.
} 
Porém é o próprio Miller ${ }^{33}$ quem propõe uma reflexão sobre a questão:

(...) embora a disposição agora seja para o diálogo, deve-se lembrar que é natural que haja um déficit de conhecimento entre cientistas e o público. Pagamos advogados e financistas para administrar nossos negócios porque eles sabem uma porção de coisas sobre leis e finanças que nós não sabemos e, a julgar pelo que pagamos, eles devem saber muito mais do que nós

\section{2. 2. 2. Outras propostas}

Outros modelos de Comunicação Pública da Ciência emergiram das discussões promovidas em torno do modelo de déficit. Shen ${ }^{\mathrm{XIX}}$, apud Krasilchik $^{35}$, em meados da década de 1970, já propunha três diferentes expressões que caracterizam o que este autor denomina como "alfabetização científica": prática, cívica e cultural. A primeira capacita o sujeito a solucionar problemas relacionados ao seu cotidiano. A segunda torna os cidadãos mais bem informados sobre as questões científicas, subsidiando-os nas tomadas de decisões coletivas que requeiram conhecimentos em ciência e seus impactos na natureza e na sociedade. Já a última, a alfabetização científica cultural, é direcionada àqueles que buscam um aprofundamento sobre assuntos que envolvam ciência.

$\mathrm{Na}$ década passada, Barros ${ }^{\mathrm{XX}}$ apud Marandino et all ${ }^{36}$ sugere cinco diferentes categorias: divulgação utilitária, divulgação do método, divulgação dos impactos, divulgação dos avanços ou evolucionista e divulgação cultural e, mais recentemente Lewenstein e Brossard ${ }^{34}$ referem-se a pelo menos três

\footnotetext{
XIX Shen, BSP. Science Literacy. In: American Sciestist. Vol. 63, p. 265-268, may-jun; 1975.

XX Barros, HGPL. Quatro Cantos de Origem. In Perspicillum : Museu de Astronomia e Ciências Afins. Vol 6, n. 1, nov. 1992.
} 
outros modelos: contextual, de experiência não acadêmica e o de participação pública. Discutiremos aqui os modelos propostos por estes dois últimos autores por entendermos estarem estes em maior concordância com o presente estudo.

\section{2. 2. 3. Modelo contextual}

Representa um avanço em relação ao modelo de déficit no sentido em que entende os receptores das informações não como meros "recipientes vazios"34, mas como indivíduos com uma história social, cultural e psicológica e que irão processar os elementos presentes nas comunicações de acordo com suas vivências ${ }^{34}$. As experiências e saberes dos indivíduos são considerados. Algumas críticas são feitas a este modelo, identificando-o apenas como uma versão mais sofisticada do modelo de déficit uma vez que reconhecem a presença de forças sociais e componentes psicológicos, não considerando, entretanto, as repostas dos indivíduos à informação. $\mathrm{Na}$ verdade, sugere-se que este modelo não estaria focado na compreensão da informação, mas sim na facilitação da aquisição desta ${ }^{37}$.

\section{2. 2. 4. Modelo de experiência leiga}

Este modelo baseia-se no conhecimento leigo. É entendido como um modelo mais democrático de $\mathrm{CPC}^{32}$ ao valorizar os saberes locais, considerando-os de igual significância ao conhecimento científico para a resolução de problemas da vida comunitária ${ }^{37}$. Esse modelo também vem questionar as verdades absolutas da ciência reconhecida como oficial e propõe o conhecimento, a experiência de vida e as próprias crenças - tão 
desconsideradas na visão de herança iluminista de nossos cientistas atuais - como saberes relevantes e importantes na busca por soluções que envolvam ciência e tecnologia ${ }^{37}$.

As críticas a esse modelo centram-se na questão de privilegiar-se 0 conhecimento local sobre o mundo natural em relação ao conhecimento produzido pelo sistema científico moderno. Para Labinger e Collins ${ }^{\mathrm{XX}}$ apud Lewenstein e Brossard ${ }^{37}$ este modelo pode ser chamado anti-ciência e seus proponentes foram alvo de algumas "das disputas virulentas das guerras da ciência'37 dos anos 1990.

\section{2. 2. 5. Modelo de participação pública}

Esse modelo, ao discutir a questão da CPC, retira o foco da difusão e da simplificação da ciência voltada para o entendimento do grande público e coloca-o na "forma em que o indivíduo consegue se apropriar do conhecimento, integrá-lo a outros saberes e usá-los nos processos de decisão,38 Propõe uma maior constância no diálogo entre cientistas e não cientistas e pressupõe uma melhor compreensão da dimensão cultural na qual a ciência encontra-se imersa ${ }^{32}$.

Assim como os demais, aqui também encontramos oposições críticas ao entendê-lo como um modelo de orientação para embasamento de políticas públicas e, portanto, voltado para políticos e ativistas nesta área, ao invés de estar direcionado à compreensão pública da ciência pela população

\footnotetext{
XXI Labinger JA; Collins, HM. The one culture? : a conversation about science. Chicago: University of Chicago Press.; 2001.
} 
em geral, privilegiando, desta forma, apenas uma pequena parcela da sociedade.

Em meio a críticas e debates, alguns autores, como Van der Auweraert 39 entendem que tanto os três modelos como o de déficit convivem e interagem sendo "todos importantes para construir uma relação sustentável entre ciência e tecnologia'39.

\section{3. Educação Ambiental}

\section{3. 1. Educação escolar: um foco nas questões ambientais}

Em meados da década de 1960, quando ainda se iniciavam as primeiras discussões ambientalistas, já se percebia o valor da educação escolar como ferramenta fundamental para esta área do conhecimento então emergente. E não apenas como possibilidade de se transmitir informações mais ampla e rapidamente, mas também, e principalmente, de sensibilização e conscientização dos indivíduos.

É sabido que, apesar dos problemas ambientais de maior magnitude terem se iniciado ao final do século XVIII, com a Revolução Industrial ${ }^{40}$, apenas no século passado, ao final dos anos 60 , o movimento ambientalista conseguiu uma organização suficiente para começar a ganhar força capaz de provocar reações de muitos dos governos instituídos em todo o mundo. Neste período, a área da educação, que vinha sendo fortemente influenciada pelo ativismo político e ideológico que marcaram esta década ${ }^{41}$, encontra na problemática ambiental um tema que se tornaria um dos norteadores das políticas educacionais até os dias de hoje. Em 1972, na primeira Conferência 
da Organização das Nações Unidas (ONU) sobre o Ambiente Humano (The United Nations Conference on the Human Environment) ${ }^{X X I I}$ a Educação Ambiental foi reconhecida como basilar para os problemas em discussão, o que gerou o Programa Internacional de Educação Ambiental ${ }^{X X I I I} 42$.

No Brasil, este período é marcado pela chamada abertura política que, apesar de "lenta, gradual e segura"43, é fato concreto e inegável. As concepções advindas dos movimentos ambientalistas identificam-se com os ideais democráticos que, aos poucos, vão ganhando força no país, influenciando grandemente a educação.

De forma crescente, a Educação Ambiental passa a fazer parte dos currículos escolares, porém, muitas vezes, alguns equívocos são cometidos. Ao analisar, no Brasil dos anos 80, o ensino de Ciências, área do conhecimento que inicialmente - e em alguns casos, até hoje - mais se vinculava à Educação Ambiental, Marandino ${ }^{14}$ nos diz:

Há uma grande crítica às metodologias ativas e uma preocupação em favorecer a melhoria da qualidade do ensino a partir da utilização de temas relativos à educação ambiental, à saúde, enfim, à realidade social. No entanto, nem sempre essa análise levava ao exame das causas econômicas e as conseqüências do uso indevido do ambiente, tendo os programas curriculares, muitas vezes, um caráter conservador e ingênuo, ou puramente naturalista.

Mesmo na década de 1990, existe a preocupação com o fato de o assunto ter tornado-se "modismo" ou "tema inevitável dos currículos" 44 e os riscos que isso poderia estar acarretando:

\footnotetext{
XXII Realizada de 5 a 16 de junho de 1972, em Estolcomo, Suécia.

XXIII Firmado em 1975, em Belgrado na ex-União das Repúblicas Socialistas Soviéticas.
} 
(...) as concepções de Educação Ambiental que, em alguns casos, têm sido entendidas como uma substituição da Educação Moral e Cívica, uma vez que os problemas atuais não são, aparentemente de ordem nacional mas internacional e, nesse sentido, têm sido proposta como uma atividade prática, sem grandes reflexões, surgindo ações educativas limitadoras, ligadas à construção de hábitos e práticas higiênicas bastante decantadas pela mídia (reciclagem de lixo, por ex.). Em outras propostas, a Educação Ambiental insere-se na Ecologia, e desvincula-se dos problemas próximos vivenciados pelos alunos, apresentando estudos sobre poluição, camada de ozônio, necessidade de preservação da Amazônia, entre outros ${ }^{44}$.

Não poderíamos deixar de citar aqui três ações que refletem as políticas públicas atualmente adotadas no Brasil, no que se refere ao tema abordado, com grande repercussão e influência no ensino básico atual de nosso país. A primeira delas é do ano de $1998^{\mathrm{XXIV}}$ quando o Ministério da Educação e Cultura (MEC) publica dentro do documento intitulado Parâmetros Curriculares Nacionais ${ }^{45}$ - que ficaria conhecido nos meios educacionais pela sigla PCN - o tema transversal Educação Ambiental. Desta forma não o propõe como uma disciplina específica, mas orienta que o tema referente às questões ambientais permeie os currículos de todas as disciplinas que compõem o quadro das séries de Ensino Fundamental e Médio. A segunda, a promulgação da Lei 9795/99 que institui a Política Nacional de Educação Ambiental, tornando obrigatória a inserção da Educação Ambiental no currículo ${ }^{10}$. E, por último, a implementação no ano de 2001 e também pelo MEC, do programa Parâmetros em Ação - Meio

\footnotetext{
XXIV Os Parâmetros Curriculares Nacionais (PCN) foram publicados entre 1995 e 1998. Contudo, o que se refere ao tema aqui tratado teve sua publicação em 1998.
} 
Ambiente na Escola ${ }^{42}$ visando reforçar e adequar as propostas dos PCN à legislação, agora renovada.

Tendo por base a definição de Educação Ambiental constante em nossa legislação, entende-se que a comunicação com o público não acadêmico realizada pelo LPAE insere-se no conceito do termo, tanto a que ocorre tendo a mídia como intermediária como aquela que acontece através das escolas.

\section{3. 2. Caminhos Percorridos pela Educação Ambiental}

O termo Educação Ambiental foi adotado pela primeira vez, no Reino Unido, em um evento de educação então promovido pela Universidade de Keele, em $1965^{46}$. Segundo Cascino ${ }^{47}$, conceituado teórico nesta área, é nesta década que o movimento ambientalista nasce, estreitamente vinculado a uma série de outros movimentos que se opunham à cultura dominante - o movimento hippie, o pacifismo, a liberação sexual, as grandes manifestações anti-Vietnã, anti-Guerra Fria, entre outros. Para citar o Brasil mais especificamente, então sob a égide do regime militar, podemos mencionar as greves, as mobilizações estudantis e a própria mensagem emancipatória contida nas publicações "Educação como Prática da Liberdade" $X X V$ e "Pedagogia do Oprimido" através das quais Paulo Freire torna-se internacionalmente conhecido ${ }^{47}$.

McCormick $^{\mathrm{XXVI}}$ apud Cascino ${ }^{47}$ nos traça um rápido panorama:

\footnotetext{
${ }^{\mathrm{XXV}}$ Freire, P. Educação como Prática da Liberdade - Rio de Janeiro: Paz e Terra;1967.

${ }^{\mathrm{XXVI}}$ McCormick, J. Rumo ao paraíso: a história do movimento ambientalista. Rio de janeiro: Relume-Dumará, 1992.
} 
O movimento ambientalista foi um produto de forças tanto internas quanto externas a seus objetivos imediatos. Os elementos de mudança já vinham emergindo muito antes dos anos 60 quando finalmente se entrecruzaram uns com os outros e com fatores sociopolíticos mais amplos, o resultado foi uma nova força em prol da mudança social e política.

Naquele momento, já não havia mais como ignorar a crise ambiental, obrigando que o tema fosse necessariamente colocado nas mesas das negociações internacionais. Apesar de este fato ser um grande avanço no sentido de que os governos de diversos países passam, então, a assumir que reconhecem o problema como importante, segundo Guimarães ${ }^{48}$, as soluções sugeridas ainda não são satisfatórias, uma vez que estas propõem a manutenção da lógica vigente "de acordo com as regras de mercado e pelo viés tecnicista"48.

As décadas de 1970 e 80 são marcadas por uma série de conferências a nível internacional que propõem discussões de caráter específico sobre a relevância e a necessidade de se vincular ambiente e educação, tornandose este tema oficial para a Organização das Nações Unidas (ONU) e alcançando projeção a nível global.

No Brasil, Educação Ambiental aparece pela primeira vez na legislação brasileira em 1973, como uma das atribuições que competiam a então SEMA (Secretaria Especial do Meio Ambiente). Entre as atribuições da SEMA, constava: "Promover o esclarecimento e a educação do povo brasileiro para o uso adequado dos recursos naturais, tendo em vista a conservação do meio ambiente" (Dec. 73.030 de 30/10/1973) ${ }^{49}$. 
Ao final da década de 1980 e durante a década de 1990 acontece, em nosso país, uma seqüência de Fóruns de Educação Ambiental ${ }^{\mathrm{XVII}}$ que tiveram como característica comum discussões que buscavam novos processos educativos, pautados por "uma ética de preservação ambiental e desenvolvimento com harmonia" ${ }^{47}$.

Naturalmente, pelas suas proporções e importância, não podemos deixar de citar a ECO-92 ou Rio-92. Realizada no Brasil, na cidade do Rio de Janeiro em junho de 1992, dela participaram 175 países estando presentes 102 chefes de estado e de governo que aprovaram e assinaram diversos documentos, sendo o mais importante deles a "Agenda 21". Com suas mais de 800 páginas, é um minucioso programa de ação, constituído de diversos tratados em diferentes campos da relação meio ambiente/economia, composto de temas que tratam desde questões como pobreza, comércio internacional e tecnologia até atmosfera, água doce, desertos e oceanos ${ }^{50}$.

Paralelamente à Conferência da ONU, ocorreu o Fórum Global, com representantes de Organizações Não Governamentais (ONG) e dos movimentos sociais de todo o planeta.

A Educação Ambiental foi um dos assuntos de maior evidência do evento, sendo que merece destaque a "Jornada Internacional de Educação Ambiental", organizada pelo Conselho Internacional de Educação de Adultos (ICAE) com o apoio de diversas ONG e onde foi elaborado o "Tratado de

\footnotetext{
XXVII I Fórum de Educação Ambiental, realizado em 1989; o II Fórum (pré-ECO-92) em abril de 1992; o III Fórum em 1994; e o IV Fórum em 1997, todos na cidade de São Paulo/SP, com exceção do último, realizado em Guarapari/ES.
} 
Educação Ambiental para Sociedades Sustentáveis e Responsabilidade Global “50.

Sem dúvida, com este tratado houve certo progresso para o próprio entendimento da Educação Ambiental uma vez que, em seus princípios básicos, foi capaz de conectar os processos de ensino/aprendizagem à busca de uma sustentabilidade para o planeta de forma mais justa e eqüitativa ${ }^{47}$.

Após o que muitos consideram como o mega evento de 1992, outra conferência importante e que influenciou os rumos que a Educação Ambiental tomou para chegar aos dias atuais foi a "Conferência Internacional sobre Meio Ambiente e Sociedade: Educação e Consciência Pública para a Sustentabilidade", realizada em Thessaloniki, na Grécia em 1997. Essa conferência também produziu um documento, a "Declaração de Thessaloniki", novamente buscando mostrar que conceitos como ética e sustentabilidade necessariamente precisam estar nas bases dos movimentos educacionais voltados para as questões ambientais, que esta deve partir da interdisciplinaridade e ser capaz de dialogar com temas como identidade e diversidade cultural. Um pouco mais aprofundado é o "Educating for a Sustainable Future: A Transdisciplinary Vision for Concerted Action" (Educação para um Futuro Sustentável: uma Visão Transdisciplinar para uma Ação Orquestrada) documento que a Organização para a Educação, Ciência e Cultura (UNESCO) organizou para essa Conferência. Partindo do questionamento "o que é sustentabilidade?", o documento se propõe a tratar dos temas educacionais basilares e de discutir os conteúdos 
até então entendidos como de concordância geral entre os educadores ambientais, sugerindo uma mudança nas práticas de Educação Ambiental, centrando a interdisciplinaridade como eixo para estas práticas e obtendo reflexões mais aprofundadas em relação aos documentos produzidos anteriormente $^{47}$

Importantes e conceituados teóricos brasileiros atuais como Marcos Sorrentino $^{51}$, Moacir Gadotti ${ }^{50}$, Carlos Loureiro ${ }^{46}$, Fábio Cascino ${ }^{47}$, Isabel Carvalho $^{49}$, Mauro Guimarães ${ }^{48}$, Martha Tristão ${ }^{52}$, entre outros, vem apontando a Educação Ambiental crítica como o caminho necessário a ser trilhado pelos educadores nesta área. A Educação Ambiental crítica alicerçase, principalmente, por princípios que orientam para um ensino voltado à mobilização politizadora dos educandos, no sentido de se rever as bases da sociedade capitalista atual e as relações de poder que a permeiam.

Sem dúvida, a tradição educativa brasileira a nós legada por Paulo Freire $^{8}$ é terreno fértil para as concepções da Educação Ambiental crítica. Contrapondo-se ao que, a partir deste autor, passou-se a denominar de educação bancária ${ }^{X X I I I}$, os ideais de uma educação libertária há muito nos fala de uma experiência única de mundo, sendo a realidade entendida por cada grupo ou sujeito de acordo com as relações que estes estabeleçam com seus contextos sócio-culturais. Segundo a teoria freiriana, o ato de ensinar carrega consigo a responsabilidade de mudar 0 sujeito da

\footnotetext{
XXVIII Educação bancária é entendida como aquela centrada no educador, que conduz os educandos à memorização mecânica dos conteúdos narrados, sem permitir qualquer dialogicidade entre educadores e educandos por entender-se que sejam os primeiros os que tudo sabem, os que dizem a palavra, os sujeitos do processo e os segundos os que nada sabem, os que escutam docilmente e objetos do processo.
} 
aprendizagem e sua forma de relacionar-se com o mundo, o que implica em mudar as relações de poder até então estabelecidas ${ }^{8}$.

A pedagogia do oprimido, que busca a restauração da intersubjetividade, se apresenta como pedagogia do Homem. Somente ela, que se anima de generosidade autêntica, humanista e não "humanitarista", pode alcançar este objetivo. Pelo contrário, a pedagogia que, partindo dos interesses egoístas dos opressores, egoísmo camuflado de falsa generosidade, faz dos oprimidos objetos de seu humanitarismo, mantém e encarna a própria opressão. $E$ instrumento de desumanização (...).

Se, porém, a prática desta educação implica no poder político e se os oprimidos não o têm, como então realizar a pedagogia do oprimido antes da revolução?

No entanto, parece-nos que apesar da grande quantidade de material teórico produzido nos últimos anos voltados para a Educação Ambiental crítica, há uma multiplicidade de diferentes ações, embasadas ou influenciadas por distintas correntes, que permeiam os trabalhos dos professores em seu dia-a-dia em sala de aula. Em seu artigo "De Tbilisi a Thessaloniki, A Educação Ambiental no Brasil", Sorrentino ${ }^{51}$ nos chama a atenção para "uma grande riqueza e diversidade de ações educacionais voltadas à questão ecológica/ambiental animadas por distintos atores".

Outra reflexão importante deste autor é a observação da necessidade de que haja flexibilidade de forma a poderem ser feitas escolhas, teóricas e práticas, inclusive para que se modifiquem com o caminhar, considerando negativo ao que ele chama de "camisa de força teórica", não deixando "espaços para as idiossincrasias e as aparentes ou reais contradições" 
Entendemos que as considerações acima se inserem de forma importante neste estudo no sentido de permitir-nos uma noção da trajetória social, cultural, política e pedagógica trilhada pela Educação Ambiental até os dias atuais, pois é através de sua dimensão histórica que podemos melhor compreendê-la no momento presente.

\subsection{Transposição Didática: saberes artesanalmente confeccionados}

Na década de 1980 surgem alguns conceitos gerados a partir de reflexões dentro da epistemologia escolar. Termos como transposição didática, mediação didática e recomposição didática são lançados no campo educacional. As duas últimas surgem das discussões propostas por Lopes $^{X X I X}$ e Tutiaux-Guillon \& Moussean ${ }^{X X X}$ apud Gabriel ${ }^{53}$, respectivamente

Já a expressão “transposição didática” é cunhada por Chevallard ${ }^{12}$ nesse mesmo período e passa a fazer parte das discussões e do vocabulário de educadores em vários países. Tanto pelo enfoque pioneiro e inovador como pela "elaboração de conceitos de inegável alcance para a compreensão do processo de construção dos saberes escolares no plano epistemológico" ${ }^{33}$, os trabalhos deste teórico ganham destaque e suscitam polêmicas.

\footnotetext{
XXIX Lopes AC. Conhecimento escolar: processos de seleção cultural e mediações didáticas. Educação e Realidade. Jan/Fev, 1997; v. 22 : p. 95-441,

${ }^{\mathrm{XXX}}$ Tutiaux - Guillon N, Moussean, M.J. Des nations à la nation, apprendre et conceptualiser. Paris, INRP, 1993.
} 
Segundo este conceito, os saberes sábios - a ciência de referência, o saber como fruto imediato das pesquisas científicas - são didaticamente transpostos, adequados de maneira a tornarem-se saberes ensinados conhecimentos capazes de serem compreendidos e assimilados por alunos das redes básicas de ensino ${ }^{12}$. Importante ressaltar que não se trata de mera simplificação da ciência dos cientistas, mas uma reconstrução, selecionando os aspectos fundamentais de cada teoria que sejam relevantes e úteis para elaboração de explicações acerca dos fenômenos naturais e reorganizando-os de acordo com as necessidades de ensino e aprendizagem.

O caminho normalmente percorrido por estes saberes inicia-se quando os resultados de pesquisas são publicados em artigos de divulgação científica. São então transpostos para os livros textos utilizados por alunos universitários e destes, então, adequados aos livros didáticos usados nos ensino Fundamental e Médio e, muitas vezes, são ainda reorganizados pelos professores em forma de apostilas e outros materiais didáticos ou simplesmente readequados no transcorrer das explicações da sala de aula.

Perrenoud ${ }^{13}$ conceitua transposição didática como a cerne do ensinar, ou seja, a ação de confeccionar artesanalmente os saberes, tornando-os ensináveis, exercitáveis e passíveis de avaliação no quadro de uma turma, de um ano, de um horário, de um sistema de comunicação e trabalho. Esse conceito traz em si a concepção de que a construção do processo ensinoaprendizagem por parte do professor dá-se numa articulação da capacidade 
pedagógica (conhecimento do processo de ensino) com a capacidade acadêmica (conhecimento de um corpo organizado de conteúdos).

Como dito anteriormente, dentro dos conceitos da transposição didática expostos acima, este trabalho se embasa na premissa de que crianças e adolescentes tem condições de entendimento dos resultados dos trabalhos do LPAE. 


\title{
CAPÍTULO 4: MÉTODOS
}

\author{
"Por isso na impaciência \\ Desta sede de saber, \\ Como as aves do deserto \\ As almas buscam beber... \\ Castro Alves ${ }^{X X X I}$
}

Este estudo tem como referencial metodológico a pesquisa qualitativa. A opção por este tipo de pesquisa baseou-se nos principais pressupostos que a norteiam, como discutimos acima, e no entendimento de ser necessária a exploração minuciosa do processo aqui estudado, das relações dinâmicas entre os sujeitos integrantes da pesquisa e entre estes e as instituições, igualmente partes complementares do objeto de estudo, além das significações que possam daí surgir. Como dito anteriormente, o enfoque principal deste trabalho é buscar analisar os processos nos quais ocorrem a CPC realizada por um laboratório de produção científica do porte do Laboratório de Poluição Atmosférica Experimental do Departamento de Patologia de Faculdade de Medicina da Universidade de São Paulo.

\subsection{Etapas de desenvolvimento da pesquisa}

Com a finalidade de viabilizar a análise proposta foram estabelecidas as etapas abaixo relacionadas:

- levantamento da inserção que as pesquisas executadas ao longo da existência do Laboratório têm na mídia, através da análise documental;

XXXI Espumas flutuantes:poesias.Rio de Janeiro:Edições de Ouro; 1964. 
- entrevistas com os cientistas do LPAE;

- levantamento dos jornalistas que entraram em contato com o LPAE para realizações de entrevistas entre janeiro de 2006 e junho de 2007;

- contato com estes jornalistas para explicação da pesquisa e convite de participação;

- envio de questionários, por correio eletrônico, aos jornalistas concordantes em participar;

- levantamento das ações de Educação Ambiental realizadas pelo LPAE;

- análise dos materiais.

\section{1. 1. Sujeitos da pesquisa}

Ao discutir sobre os sujeitos pesquisados em pesquisa qualitativa, Chizzotti $^{17}$ nos diz que todos os que participam devem ser reconhecidos como "sujeitos que elaboram conhecimentos e produzem práticas adequadas para intervir nos problemas que identificam." Entende-se, portanto, que esses sujeitos trazem consigo conhecimento prático e representações sobre o assunto em questão, em grau de complexidade suficiente para direcionar suas atitudes e ações cotidianas. Esta idéia muito vem sendo discutida e é alicerçada nos ideais filosóficos dos séculos XVIII e XIX. Porém, este autor chama a atenção para um detalhe que, nos parece, deva ser ressaltado neste trabalho. O fato de possuírem vivência e conhecimento prático não significa, necessariamente, que essas pessoas tenham desenvolvido "conhecimento crítico"17 sobre o assunto pesquisado e 
que sejam capazes de contextualizar esses saberes de forma global ou, nas palavras do próprio Chizzotti" ${ }^{17}$, "que relacione esses saberes particulares com a totalidade, as experiências individuais com o contexto geral da sociedade".

No presente trabalho, podem ser consideradas três categorias de sujeitos da pesquisa:

1. cientistas do LPAE;

2. jornalistas que entrevistaram os cientistas do LPAE;

3. professores que participaram do curso "Poluição e Saúde Projetos Ambientais e a Escola" (PoSPAE).

\section{1. 1. 1. Cientistas}

Todo o material de pesquisa do LPAE é produzido por uma equipe de cerca de 80 profissionais, sendo que grande parte das pessoas que aí trabalham ou desenvolvem seus projetos de pesquisa não possuem qualquer vínculo contratual com o Laboratório, podendo ser considerada como uma "população flutuante". A maioria destes profissionais se mantém no LPAE pelo período de duração de seus projetos, seja de iniciação científica, mestrado ou doutorado, exceção feita a alguns poucos pesquisadores que, mesmo sem qualquer vinculação profissional formal, atuam de forma constante nas atividades do Laboratório.

Para efeito desta pesquisa, foram realizadas entrevistas com os pesquisadores compromissados de forma diferenciada com os trabalhos desenvolvidos pelo LPAE utilizando-se os critérios expostos a seguir.. 
Identificou-se dois grupos aqui distinguidos como as equipes formal e não formal. A primeira composta por 10 cientistas que possuem algum vínculo empregatício com o LPAE e que participam de forma sistemática das pesquisas aí realizadas. Além destes, foram ainda incluídos os pesquisadores que, mesmo não possuindo vínculo formal com o Laboratório, tenham atualmente participação expressiva nos trabalhos. A seleção deste último grupo deu-se a partir da indicação do chefe do Laboratório que, com este perfil, recomendou quatro pesquisadores.

Foram entrevistados:

\section{Equipe formal}

E1. Paulo Hilário do Nascimento Saldiva, Médico e Professor Titular da Universidade de São Paulo desde 1980, Chefe do Departamento de Patologia, Livre Docente.

E2. Miriam Lemos, Biomédica contratada (celetista) desde 1987, com título de pós-doutorado. Obs.: Esteve fora do país no período entre outubro de 2002 a novembro de 2006.

E3. Mariângela Macchione, Química contratada (celetista) desde 1988, com título de pós-doutorado.

E4. Eliane Tigre Guimarães Sant'Anna, Biologista contratada (celetista), trabalhando no LPAE desde 1989, doutora em Ciências;

E5. Ana Júlia de Faria Coimbra Lichtenfels, Biologista contratada (celetista) desde 1991, doutora em Fisiopatologia Experimental; 
E6. Dolores Helena Rivero, biologista contratada (celetista) desde 1994, doutora em Ciências;

E7. Luiz Alberto Amador Pereira, Médico comissionado (Secretaria de Saúde do Estado de São Paulo) desde 1995, doutor em Medicina;

E8. Débora-Jã de Araújo Lobo, Biologista contratada desde 1996, mestre em Medicina (Pneumologia);

E9. Heloísa Maria Bueno Guimarães, Biologista contratada (celetista) desde 1996, doutora em Ciências;

E10. Regiani Carvalho de Oliveira, Biologista contratada (celetista) desde 1999, doutora em Ciências.

\section{Equipe não formal}

E11. Chin An Lin, Médico, doutor em Medicina;

E12. José Eduardo Delfini Cançado, Médico, doutor em Ciências;

E13. Marcos Abdo Arbex, Médico, doutor em Ciências;

E14. Marisa Dolhnikoff, Médica, com título de pós-doutorado.

Obs.: Dentre os pesquisadores não contratados, porém com intensa participação nos trabalhos do LPAE encontra-se, também, o Prof. Dr. Alfésio Luiz Ferreira Braga, que não será aqui considerado por tratar-se do professor orientador desta tese.

Por questões de ordem prática, os pesquisadores passarão a ser identificados pela sigla que antecede seus nomes na relação acima. 
Devido às características particulares deste grupo - todos com amplo conhecimento sobre os processos de produção de pesquisas científicas procurou-se evitar perguntas diretas, que poderiam induzir à respostas tidas como "sabidamente corretas" pelos entrevistados. Buscou-se elaborar questionamentos que estimulassem a fala dos cientistas sobre o LPAE, seu alcance, formas de comunicação dentro e fora do meio científico bem como motivações para se promover a CPC. Houve a intenção de retratar-se, com a maior fidelidade possível, o entendimento destes cientistas em relação ao tema. As questões propostas aos entrevistados podem ser consultadas no Anexo A.

Desta forma, as entrevistas concedidas foram analisadas com base no referencial teórico-metodológico proposto.

\section{1. 1. 2. Jornalistas}

Foram incluídos neste grupo 34 jornalistas de 24 diferentes veículos de comunicação que contataram o LPAE para realização de entrevistas e/ou matérias que envolvessem este laboratório entre janeiro de 2006 e junho de 2007. Para e seleção deste grupo realizou-se um levantamento nas agendas da secretária do LPAE. Houve, ainda, a indicação por parte da secretária, já que nem todas as entrevistas foram agendadas previamente.

Entre os jornalistas contatados, 19 profissionais de 16 diferentes veículos de comunicação responderam ao questionário. São eles: 


\begin{tabular}{|c|c|c|c|}
\hline Sigla & Nome do jornalista & $\begin{array}{l}\text { Nome do veículo de } \\
\text { comunicação }\end{array}$ & $\begin{array}{l}\text { Tipo do veículo } \\
\text { de comunicação }\end{array}$ \\
\hline J1 & $\begin{array}{l}\text { Fernanda de Souza } \\
\text { Aranda }\end{array}$ & Jornal da Tarde & Jornal impresso \\
\hline J2 & $\begin{array}{l}\text { Marcela } \quad \text { Valença } \\
\text { Spinosa }\end{array}$ & Jornal da Tarde & Jornal impresso \\
\hline J3 & Afra Balazina & Folha de São Paulo & Jornal impresso \\
\hline J4 & Simone Iwasso & $\begin{array}{l}\text { O Estado de São } \\
\text { Paulo }\end{array}$ & Jornal impresso \\
\hline J5 & Renata Mauro Miranda & $\begin{array}{l}\text { O Estado de São } \\
\text { Paulo }\end{array}$ & Jornal impresso \\
\hline $\mathrm{J} 6$ & $\begin{array}{l}\text { Márcia Seidensticker } \\
\text { Guedes }\end{array}$ & Revista Alphanews & Revista impressa \\
\hline J7 & $\begin{array}{l}\text { Cristina Ribeiro Nabuco } \\
\text { Martrucelli }\end{array}$ & Revista Claudia & Revista impressa \\
\hline J8 & Cinderela Caldeira & $\begin{array}{l}\text { Revista } \quad \text { Espaço } \\
\text { Aberto }\end{array}$ & Revista impressa \\
\hline J9 & Aureliano Biancarell & $\begin{array}{l}\text { Revista Fórum } \\
\text { Folha de São Paulo }\end{array}$ & $\begin{array}{l}\text { Revista impressa } \\
\text { Jornal impresso }\end{array}$ \\
\hline J10 & Felipe Alan Rifa & $\begin{array}{l}\text { Revista } \quad \text { Planeta } \\
\text { Cidade }\end{array}$ & Revista impressa \\
\hline J11 & Anderson Moço & $\begin{array}{l}\text { Revista Saúde É } \\
\text { Vital! }\end{array}$ & Revista impressa \\
\hline J12 & $\begin{array}{l}\text { Renata } \quad \text { Okumura } \\
\text { Oliveira }\end{array}$ & Eldorado AM & Rádio \\
\hline J13 & $\begin{array}{l}\text { José Armando Vanucci } \\
\text { Leiros }\end{array}$ & Jovem Pan & Rádio \\
\hline J14 & $\begin{array}{l}\text { Michelle Pena Povoa } \\
\text { Dufour }\end{array}$ & TV Cultura & Televisão \\
\hline J15 & Natália Ariede & TV Globo & Televisão \\
\hline J16 & Carla di Cologna & O Eco & Mídia on line \\
\hline
\end{tabular}




\begin{tabular}{l|l|l|l}
\hline Sigla & Nome do jornalista & $\begin{array}{l}\text { Nome do veículo de } \\
\text { comunicação }\end{array}$ & $\begin{array}{l}\text { Tipo do veículo } \\
\text { de comunicação }\end{array}$ \\
\hline $\mathbf{J 1 7}$ & Gustavo Faleiros & O Eco & Mídia on line \\
\hline $\mathbf{J 1 8}$ & $\begin{array}{l}\text { João Maurício Teixeira } \\
\text { da Costa }\end{array}$ & O Eco & Mídia on line \\
\hline $\mathbf{J 1 9}$ & Fábio de Castro & $\begin{array}{l}\text { Agência Fapesp de } \\
\text { Comunicação } \\
\text { Agência Repórter } \\
\text { Social }\end{array}$ & \multicolumn{2}{|l}{} \\
\hline
\end{tabular}

Por questões de ordem prática, os jornalistas passarão a ser identificados pela sigla que antecede seus nomes na relação acima.

\section{1. 1. 3. Professores}

Inseriram-se neste grupo todos os 23 professores que participaram do Curso PoSPAE.

\section{2. Procedimentos de coleta e análise de dados}

Foram utilizados como instrumentos para coleta de dados da pesquisa:

- levantamento documental: consulta das agendas do Dr. Saldiva e dos documentos do LPAE referentes tanto ao material científico publicado como às matérias divulgadas pela imprensa não acadêmica;

- entrevistas semi-estruturadas: realizadas com o grupo de pesquisadores discriminado (Anexo $A)$;

- questionários: aplicados aos jornalistas deste estudo (Anexo B); 
- observação: técnica utilizada no curso PoSPAE e no acompanhamento dos professores participantes do Projeto Estação Ambiência.

Para proceder-se a análise de dados, utilizou-se a análise de conteúdo, explicitada a seguir. Há, ainda, a análise bibliográfica, que perpassou todo este trabalho e importante fonte de dados. Esses instrumentos e a forma de utilização são descritos abaixo.

\section{2. 1. Levantamento Documental}

$\mathrm{Na}$ avaliação da inserção junto à mídia, foi realizado o levantamento das reportagens e entrevistas direcionadas ao público não acadêmico que, de alguma forma, remetem ao Laboratório. Para tanto, utilizou-se as seguintes fontes de documentos:

compilação intitulada "Artigos de Divulgação do Laboratório de Poluição Atmosférica Experimental” que reúne cópias das reportagens e entrevistas veiculadas pela mídia impressa de 1982 a maio de 2005 e que, segundo a secretária atual, Maria Dalva Gomes Santana, neste documento estão a maioria das publicações feitas pela imprensa não acadêmica que se refiram ao Laboratório neste período. No anexo C encontra-se seu resumo;

reportagens e entrevistas impressas de junho 2005 a junho de 2007 arquivadas pela secretaria do LPAE foram igualmente consideradas, como complemento ao documento anterior. No anexo C encontra-se seu resumo;

agendas de trabalho do Dr. Saldiva dos anos de 2003 a junho de 2007. Estes documentos foram utilizados com o objetivo de se ter uma idéia 
das reportagens e entrevistas concedidas à imprensa televisiva e radiofônica além das palestras e conferências realizadas pela equipe do LPAE ao público não acadêmico. As agendas dos anos anteriores, bem como as agendas de Dr. Böhm, não foram guardadas, impossibilitando a consulta;

$>$ agendas da secretária do LPAE quanto às da chefia referentes ao ano de 2006 e ao primeiro semestre de 2007 foram igualmente utilizadas para o levantamento de jornalistas que contataram o LPAE neste período. Estes jornalistas foram posteriormente contatados;

buscadores de sítios da Worldwide Web.

Foram, ainda, importantes fontes de informação em relação à participação da equipe em diferentes programas televisivos e radiofônicos, bem como em palestras e conferências, as secretárias da chefia do LPAE, Eliane Falconi Mônico Gazetto (secretária entre 2003 e 2006), e Maria Dalva Gomes Santana (secretária entre 2006 e 2007), além do próprio Dr. Paulo Saldiva.

\section{2. 2. Entrevistas}

A entrevista vem sendo considerada pela maioria dos estudiosos desta área - Thiollent ${ }^{54}$, Ludke e André ${ }^{15}$, Triviños ${ }^{16}$, Alves-Mazzotti e Gewandsznajder $^{18}$ e Richardson ${ }^{55}$ - como um dos instrumentais básicos para coleta de dados em pesquisas qualitativas. Uma série de tipos de entrevistas, que variam de acordo com o grau de controle que o entrevistador exerce sobre o diálogo, é descrito por Rubin \& Rubin apud Gewandsznajder e Alves-Mazzotti ${ }^{18}$ e, entre elas encontra-se a entrevista 
"semi-estruturada", escolhida para este estudo. Este tipo de entrevista pode ser designada como aquela que é formatada apoiada em questionamentos básicos de interesse da pesquisa permitindo uma abertura vasta para novos questionamentos, surgidos da interação entre entrevistador-entrevistado.

Esta opção foi feita baseada em importantes e diferentes autores como, além dos citados, Bauer e Gaskell ${ }^{19}$ que destacam a relevância que tem, para trabalhos nos moldes como o que aqui se apresenta, a espontaneidade dos pesquisados tanto nas formas de expressão como em suas falas. "Dados informais são gerados menos conforme regras de competência, tais como capacidade de escrever um texto (...) e mais do impulso do momento, ou da influência do pesquisador"19.

Ludke e André ${ }^{15}$ sugerem um roteiro de condução, onde haja uma ordem natural, tanto lógica como psicológicas. "Na medida em que houver um clima de estímulo e aceitação mútua, as informações fluirão de maneira notável e autêntica" afirmam as autoras. Avaliam, ainda, que não há receita infalível, mas alguns cuidados básicos que podem garantir uma boa entrevista. Entre estes cuidados pode ser citado a "atenção flutuante" termo usado por Thiollent apud Ludke e André ${ }^{15}$ para designar a atenção que deve ser dada aos sinais não verbais ao longo da entrevista "toda uma gama de gestos, expressões, entonações (...) hesitações, alterações de ritmo, enfim, toda uma comunicação não verbal cuja captação é muito importante para compreensão e validação do que foi efetivamente dito".

Embasado no acima exposto, foram organizadas entrevistas a partir dos tópicos dos objetivos do projeto e elaborado um desenho básico e 
flexível, disposto de forma lógica e mantendo o encadeamento dos temas (anexo A). Este desenho permitiu que fosse criado um espaço tanto para uma caracterização mais aprofundada dos sujeitos da pesquisa quanto para a ampliação da própria entrevista ao surgirem outras proposições e temas durante o processo que não haviam sido contemplados.

As entrevistas foram filmadas sendo posteriormente transcritas.

\section{2. 3. Questionários}

Segundo Chizzotti ${ }^{17}$ o questionário pode ser uma importante fonte de dados, desde que apresente estrutura lógica e linguagem acessível. Ainda segundo este autor, este tipo de questionário pode ser entendido como uma interlocução planejada.

Foi efetivado, inicialmente, um contato telefônico com os jornalistas selecionados para participarem do estudo. Em seguida, foram enviados por correio eletrônico, termos de consentimentos e questionários com perguntas pré-elaboradas, colocadas em seqüência lógica e sistemática. Para este estudo, foram selecionadas questões que se referiam às relações destes jornalistas com cientistas em sua carreira profissional, não se restringindo aos pesquisadores do LPAE.

\section{2. 4. Observação}

Triviños $^{16}$ define "observar" como "destacar de um conjunto (...) algo especificamente, prestando, por exemplo, atenção em suas características”.

A observação sistemática, também denominada de estruturada ou controlada, juntamente com a entrevista e a análise de dados, pode ser 
considerada um dos apoios do "tripé" de coleta de dados em pesquisas qualitativas. Esta técnica utiliza-se de instrumentos que permitam manter a maior fidelidade possível acerca dos dados e fatos observados, cuja padronização possibilita o controle das variáveis ambientais ${ }^{56}$.

Diferentemente da pesquisa tradicional que, apesar de lançar mão desta técnica a considera dispendiosa, já que exige um investimento de tempo grande por parte do pesquisador além de pouco confiável no sentido que a presença do observador é capaz de interferir no caso em foco ${ }^{18}$. Porém, ao considerarmos os pressupostos e características da pesquisa qualitativa, percebemos primeiramente que o dispêndio de tempo é essencial quando se busca apreender significados ligados a comportamentos humanos e só poderá ser considerado demasiado se comparado com técnicas de questionários de aplicação coletiva, estes realizados em questões de horas ou, no máximo, alguns dias. Quanto à questão da interferência do observador na situação, existe não só o argumento da permanência por longo período de tempo do pesquisador junto ao grupo, o que permite uma aceitação por parte dos sujeitos da pesquisa e mesmo uma banalização da presença do observador, deixando de ser algo diferente a ponto de alterar de forma importante a situação observada, ou

"pode-se considerar, ainda, como preferem os teóricos-críticos, que as relações sociais que se estabelecem entre pesquisador e pesquisados não são diferentes daquelas que existem na sociedade, e como tal devem ser encaradas e discutidas"18. 
No acompanhamento ao trabalho dos professores participantes do curso PoSPAE entre outubro de 2006 e junho de 2007, utilizou-se da técnica aqui descrita. Foram considerados como instrumentos para embasamento e respaldo desta técnica os formulários "perfil do professor", preenchidos pelos participantes do curso antes do início da primeira aula, as listas de presença e avaliações realizadas pelos professores durante o curso assim como as listas de presenças das reuniões de acompanhamento.

\section{2. 5. Análise de conteúdo}

Optou-se aqui utilizar-se o conceito de análise de conteúdo por ser este mais amplo que o de análise documental e estar em maior consonância com os propósitos desta pesquisa. Enquanto a segunda limita-se analisar apenas os documentos restringindo-se, portanto, ao material escrito ${ }^{\mathrm{XXII}}$, a análise de conteúdo é mais abrangente por tratar-se da análise de qualquer comunicação (escrita, oral, visual, gestual) ${ }^{17}$. Bardin $^{\mathrm{XXXII}}$ apud Triviños ${ }^{16}$ caracteriza este tipo de análise como tendo, entre outras peculiaridades, a de ser uma forma de se estudar as comunicações entre os homens, realçando-se o conteúdo das mensagens.

Esta técnica tem uma longa história, remetendo-se às primeiras tentativas de interpretar os livros sagrados. A partir do século XVII já se tem registros de esforços ordenados acontecendo na Europa, mas ganha caráter sistemático, adquirindo as formas organizadas de um método de investigação, após a Primeira Guerra Mundial $(1914-1919)^{16}$.

\footnotetext{
XXXII "Considera-se como documento qualquer registro escrito que possa ser usado como fonte de informação". (Gewandsznajder e Alves-Mazzotti,1998; p. 169)

XxXIII Bardin, L. L'analyse de contenu. Paris: Presses Universitaires de France; 1977.
} 
Atualmente, é vista como um "método de tratamento e análise de informações, colhidas por meio de técnicas de coleta de dados"17 cujo objetivo é a compreensão crítica do sentido das comunicações, seu conteúdo e significações, sejam estas explícitas ou ocultas.

Para facilitar sua aplicação, o processo de análise de conteúdo pode ser dividido, em três etapas básicas (Bardin ${ }^{\mathrm{XXIV}}$, apud Triviños ${ }^{16}$ ):

- pré-análise: consiste na organização do material;

- descrição analítica: estudo minucioso do corpus do material;

- interpretação referencial: exame do conteúdo latente. Indo além do conteúdo manifesto, nesta fase busca-se aprofundar a análise fazendo-se uso da reflexão e da intuição, com base nos materiais empíricos e procurando abrir perspectivas, perceber tendências, ideologias e, em oposição à análise específica do conteúdo manifesto - característico das pesquisas de linha positivista - é um processo ativo e histórico.

As análises de conteúdo realizadas neste trabalho basearam-se nas propostas acima referenciadas

Este trabalho foi aprovado pela Comissão de Ética para Análises de Projetos de Pesquisa da Diretoria Clínica do Hospital das Clínicas e da Faculdade de Medicina da Universidade de São Paulo.

XXXIV Bardin, L. L'analyse de contenu. Paris: Presses Universitaires de Frande; 1977. 


\section{CAPÍTULO 5: RESULTADOS}

"Há alguma exageração nisto, mas o discurso humano é assim mesmo, um composto de partes excessivas e partes diminutas que se compensam, ajustando-se. Por outro lado, se entendermos que a audiência aqui não é de orelhas, senão de memória, chegaremos à exata verdade."

Machado de Assis ${ }^{X X X V}$

\section{1. LPAE E A MÍDIA NÃO ACADÊMICA}

\section{1. 1. Levantamento das Publicações Científicas}

Em junho de 2007 o LPAE contava com 385 trabalhos publicados ou em fase de publicação, sendo 383 completos, um em fase de análise pelo periódico ao qual foi submetido e um no prelo, conforme relação cedida pela secretária do LPAE, Maria Dalva Gomes Santana.

Tabela 1 - Número de artigos científicos publicados pelo LPAE em revistas especializadas entre 1982 e o primeiro semestre de 2007

\begin{tabular}{cccc}
\hline ano & Número & ano & Número \\
1982 & 01 & 1995 & 14 \\
1983 & 02 & 1996 & 11 \\
1984 & 02 & 1997 & 18 \\
1985 & 09 & 1998 & 19 \\
1986 & 08 & 1999 & 18 \\
1987 & 12 & 2000 & 17 \\
1988 & 09 & 2001 & 30 \\
1989 & 08 & 2002 & 34 \\
1990 & 06 & 2003 & 26 \\
1991 & 03 & 2004 & 36 \\
1992 & 13 & 2005 & 37 \\
1993 & 06 & 2006 & 22 \\
1994 & 09 & $2007\left(1^{\circ}\right.$ & 13 \\
& & semestre $)$ & 383 \\
\hline
\end{tabular}

Tabela $1{ }^{\star}$ QTP: quantidade de trabalhos publicados

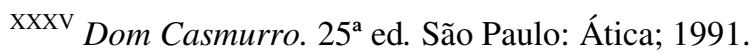


Conforme pode ser observado na tabela acima, até 1984 apenas 05 trabalhos haviam sido publicados pelo LPAE. Gradativamente vem ocorrendo um aumento no número de publicações, sendo que a partir de 2001 o Laboratório tem publicado uma média de 30 trabalhos por ano.

\section{1. 2. Levantamento das comunicações não acadêmicas}

As diferentes fontes de informações aqui utilizadas e anteriormente especificadas permitiram o levantamento das comunicações não acadêmicas realizadas pelo LPAE conforme abaixo:

> compilação "Artigos de Divulgação do Laboratório de Poluição Atmosférica Experimental" e arquivo de entrevistas e reportagens impressas.

Esta compilação reúne 84 publicações, entre reportagens, entrevistas e artigos noticiados pela imprensa não acadêmica escrita e outras 65 foram levantadas tanto a partir dos arquivos como das agendas das secretárias do LPAE entre maio de 2005 e junho de 2007. As agendas foram utilizadas como critério para busca de matérias publicadas sobre o LPAE na Web, uma vez que mais de 500 páginas são geradas quando o nome completo do Laboratório é digitado em buscadores de sítios, conforme especificamos abaixo. Foram incluídas publicações localizadas na Worldwide Web a partir de agendamentos de entrevistas.

No período de abrangência dos documentos acima citados percebe-se que os temas pelos quais o LPAE foi procurado o maior número de vezes pela mídia impressa foram os que associam a poluição à saúde humana, assunto que faz parte de 60 matérias $(40,26 \%)$ entre as 149 pesquisadas; 
poluição por automóveis, surgindo 43 vezes $(28,85 \%)$, e os que correlacionam poluição à mortalidade infantil ou adulta, temas recorrentes a 23 matérias (15,43\%).

\section{Agendas do Dr. Saldiva}

Através destes documentos, pôde-se elencar diferentes emissoras de rádio e televisão que solicitaram entrevistas. No entanto, como na maioria das anotações não constam os nomes dos programas e, segundo a secretária do LPAE, muitas das entrevistas não foram agendadas, pois é comum a solicitação destas sem um contato prévio, muitas informações em relação à participação do Dr. Saldiva em diversos programas televisivos e radiofônicos foram fornecidas pelo próprio Dr. Saldiva como pelas secretárias.

Muitos destes programas alcançam grande audiência a nível nacional, entre os quais podem ser citados: "Fantástico", "Jornal Nacional", "Globo Ecologia", "Globo Ciência", "Programa do Jô", todos veiculados pela Rede Globo de Televisão que, "com 113 emissoras entre geradoras e afiliadas, pode ser assistida em 99,84\% dos 5.043 municípios brasileiros" "57; "Repórter ECO", "Programa Silvia Popovic", "Programa Via Legal", estes veiculados pela TV Cultura, emissora mantida pela Fundação Padre Anchieta - Centro Paulista de Rádio e TV Educativas - cujo sinal é recebido em 21 estados mais o Distrito Federal, atendendo 1481 localidades $^{58}$. Além dessas, outras entrevistas concedidas a emissoras de televisão constam nas agendas de Dr. Saldiva como a BBC de Londres, TV Record, TV Bandeirantes (Programa "Comando da Madrugada"), Rede Nova Geração Televisão 
(GNT, canal 48 UHF) e TV USP. Da imprensa radiofônica, podem ser citadas Rádio Bandeirantes, Rádio CBN, Rádio USP e Rádio Trianon.

Palestras e conferências também chegam ao público não acadêmico de maneira significativa. Em audiências públicas, a convite da comunidade ou de Organizações Não Governamentais, apesar de escassos registros na agenda de Dr. Saldiva, segundo este, são realizadas cerca de 40 palestras deste tipo por ano, alcançando cerca de 1600 pessoas.

> Outra ferramenta importante de comunicação e divulgação para o público não acadêmico atualmente é através da Worldwide Web. Ao se colocar o nome completo do Laboratório em buscadores de sítios, foram geradas 536 páginas através do Google ${ }^{59}, 219$ através do Yahoo! Search ${ }^{60}$, 203 através da AltaVista ${ }^{61,}, 185$ páginas através do Alltheweb ${ }^{62}$ e 162 através da StarMedia ${ }^{63}$. Foram realizadas pesquisas apenas nos buscadores de sítios com a opção "busca avançada", ou seja, onde a procura fosse realizada a partir de toda a expressão a ser consultada e não a partir de cada palavra contida na expressão, uma vez que esta última mostraria vários sítios onde houvesse apenas a palavra "laboratório", outros "poluição", e assim por diante.

Apesar de em algumas destas páginas constarem os artigos científicos publicados na íntegra, não sendo, portanto, direcionadas ao público não acadêmico, a grande maioria traz matérias ou reportagens elaboradas pela mídia não acadêmica. 


\section{1. 3. Entrevistas realizadas com os cientistas}

Dentro do objetivo de analisar as principais questões que permeiam as relações entre cientistas ligados à área da saúde e profissionais da mídia não acadêmica foram realizadas entrevistas com os cientistas segundo os critérios já mencionados. Foi adotado um esquema de estruturação que, focado nos objetivos principais da entrevista, permitiu certa margem de "mobilidade" nas respostas.

Nas respostas obtidas os temas foram separados como forma de facilitar a análise.

\section{1. 3. 1. Origem motivadora}

O chefe do LPAE verbaliza de forma clara ao expressar a origem motivadora para que 0 Laboratório busque alcançar o público não acadêmico

(...) a gente está sempre avaliando risco (...) só que você vai ficando mais velho, você quer também resolver o problema. E para resolver o problema, na nossa área, tem que se basear em mudanças de comportamento, e aí você tem que transmitir esse conhecimento. Então a nossa idéia de atingir o grande público vem dessa necessidade. (E1)

Dentro desta idéia, os demais componentes da equipe demonstram com maior nitidez esses motivadores quando questionados quanto aos objetivos que o LPAE deva cumprir. Indo além do basilar - "fazer pesquisa, formar pesquisadores e ensinar alunos" (E1) - 64,28 \% aponta a "disseminação do conhecimento", expressão utilizada por uma das 
pesquisadoras (E8) e idéia compartilhada não só pela chefia mas também por outros sete. Um deles nos coloca a opinião recorrente de forma clara:

(o LPAE) é um lugar onde se produz conhecimento que precisa ser passado para a sociedade afim de que haja um retorno desse conhecimento, e essa passagem do conhecimento tem que gerar benefícios para a sociedade, tanto em termos de bem estar geral como em termos de saúde. (E11)

\section{1. 3. 2. Inserção na Comunidade Científica}

A fala de um dos cientistas sintetiza bem a opinião geral em relação à inserção do LPAE na comunidade científica:

No meio acadêmico, eu acho que o Laboratório consegue alcançar as expectativas. Ele é um laboratório que faz parte de um programa de pósgraduação em pesquisa, que tem uma nota muito alta na CAPES ${ }^{X X X V !}$. É um laboratório que é respeitado internacionalmente pelos seus pares, no meio acadêmico, e é um laboratório que tem uma produção científica muito forte. E os grupos, tanto o grupo de epidemiologia, quanto os grupos que realizam trabalhos experimentais e clínicos, tem uma força muito grande, tem uma inserção muito forte em comunicações internacionais. Eu acho que, no meio acadêmico, o Laboratório até supera as expectativas. (E7)

A única ressalva aparece quando outra cientista reflete sobre a inserção do LPAE dentro da própria Universidade de São Paulo:

Dentro da Universidade, eu acho meio complicado a gente avaliar isso, eu não consigo avaliar a não ser no meu cotidiano. Nós temos vários intercâmbios, com vários outros laboratórios, vários

\footnotetext{
XXXVI Coordenação de Aperfeiçoamento de Pessoal de Nível Superior. Órgão responsável pela avaliação da pós-graduação stricto sensu em todos os estados da Federação
} 
outros grupos de estudo, de outros estados, até de outros países, mas eu não sei até que ponto isso repercute no meio acadêmico em que a gente está inserido, em termos de valorização. (E10)

\section{1. 3. 3. Inserção junto ao público não acadêmico}

Porém as opiniões não são tão uniformes quando se trata de avaliar a inserção que o LPAE tem junto ao público não acadêmico. Oito deles $(57,14 \%)$ acreditam que esta entrada pode ser avaliada como boa seja pelo fato de considerarem Dr. Saldiva uma pessoa popular, capaz de extrapolar o meio acadêmico, seja por avaliarem que o tema "poluição" é de interesse geral da população. Uma das entrevistadas (E4) refletiu sobre a questão de esta "boa inserção" se dar com o público de uma forma geral ou estar restrita aos que "estão interessados no assunto" e conclui: "às vezes, na verdade, (alcança) até aqueles que não são tão interessados, está no Jornal Nacional, que todo mundo acaba assistindo". Porém, o próprio chefe e mais três pesquisadores, $(28,57 \%)$ discordam, ao manifestarem que "ainda é pouco". Segundo um deles há necessidade de um aprofundamento maior por parte da imprensa não acadêmica, sendo possível uma melhora neste tipo de comunicação.

Em relação a outros meios (não acadêmicos), eu já não vejo com tanta inserção assim, com tanta força. Eu acho que falta para o Laboratório uma inserção mais ágil e mais forte com a comunidade, por exemplo (E7).

Este pesquisador aponta, inclusive, para o fato de considerar muito tímida a participação do LPAE em projetos que envolvam Educação Ambiental. Tanto a chefia como dois outros cientistas apresentaram 
sugestões, como a melhor estruturação da home-page do Laboratório (E1) ou um assessor de comunicação "que pudesse nos ajudar nesse sentido" (E7), "um meio de ligação entre a mídia, o Laboratório e o pesquisador" (E12). Quatro entrevistados (28,57\%) citaram o fato de haver uma maior procura por informações do Laboratório pela imprensa não acadêmica no período de inverno, devido às constantes inversões térmicas e conseqüentes agravamentos dos problemas de saúde relacionados à poluição atmosférica. Nota-se, no entanto, um diferencial de como esse fato é visto entre eles. As três primeiras o citaram como um exemplo da boa inserção do LPAE junto ao público não acadêmico

Toda a época de inverno, no meio do ano de junho a agosto e setembro a televisão vem visitar o Laboratório - Globo, Record, essas emissoras - para fazer uma entrevista com nosso chefe ou com os pesquisadores, eles sempre reportam o trabalho que está em andamento, o que de diferente a gente descobriu (E2).

Já outro entrevistado faz esta referência quando avalia que esta inserção poderia ser melhorada:

(...) só naqueles momentos onde a poluição está mais alta, que surgem os problemas, que a mídia vem nos procurar. Isso é cíclico, geralmente no inverno, que tem os períodos de inversão térmica, mas não existe uma continuidade de informação e uma interface com alguns setores da comunidade talvez que possam se interessar pelo nosso trabalho - organizações não governamentais e etc.(E7). 


\section{1. 3. 4. Vontade expressa: interferir na política ambiental}

Interferir, através dos resultados das pesquisas executadas pelo LPAE, na política governamental relacionada às questões ambientais, também é uma vontade expressa por $57,14 \%$ dos pesquisadores. Este fato pode ser observado nas falas de duas pesquisadoras, e recursivas em seis colegas.

(...) executar a pesquisa, realizar a pesquisa, saber o que a poluição ambiental está causando na saúde da população, e com isso, de certa forma, incomodar as autoridades para que façam alguma coisa em prol da melhoria do meio ambiente no modo geral (E4).

Existe um interesse que é de tentar contribuir com informação na área da saúde para que as autoridades governamentais tomem alguma atitude, para tentar amenizar o problema (E2).

Uma delas coloca claramente essa como uma meta ainda não totalmente alcançada: “(...) e o que eu acho que pouco a gente consegue alcançar, por exemplo, é com relação à política governamental da nossa cidade. A gente não conseguiu, ainda, mexer com a parte de melhoria de transportes"(E6).

\section{1. 3. 5. Possibilidades de Compreensão}

Quando questionados quanto às possibilidades de compreensão das pesquisas do LPAE, houve unanimidade no sentido de que essa compreensão é possível, porém algumas ressalvas surgiram quanto à possibilidade de se transmitir todas as informações resultantes. Algumas colocações $(42,85 \%)$ demonstram a percepção de que há limites para a transmissão dessas informações: “(...) tem coisas que dá, tem coisas que 
não dá (para transmitir)" (E9). Ou ainda "tem limites, mesmo você simplificando o teor da linguagem" (E6) opinião justificada por uma experiência pouco satisfatória vivenciada por esta entrevistada:

(...) eu já tive essa experiência: de você dar uma entrevista e o repórter não entender, não saber nem o que é oxigênio, como é um vaso sanguíneo, (...) deturpou toda a entrevista e, no caso, publicou aquilo. (...) um médico que lê aquilo, fala: isso não é verdade (E6).

Interessante notar que um dos pesquisadores, apesar de relatar experiência similar à citada acima, está entre a maioria que entende que tudo pode ser transmitido, bastando adequar a linguagem:

Várias vezes eu li coisas que eu não disse nas entrevistas (...) às vezes a pessoa vem com a idéia pré-concebida e (...) a grande maioria das vezes eu não fiquei satisfeito com as entrevistas (...). li e tenho lido coisas que não são reais, isso é um cuidado que a gente tem que ter (E7).

Destacamos aqui uma ponderação que entendemos tornar mais clara essa idéia ao ressaltar que, mesmo havendo limites para a compreensão total da pesquisa, esse é um fator secundário quando se trata de população não acadêmica:

Tem limites, claro (...) mas acho que isso não é o mais importante. Acho que o mais importante é a mensagem que essa pesquisa tem, o resultado final dessa pesquisa, que aí eu acho que a capacidade de compreensão da população em relação a isso é total (E14). 
Ainda assim, é na fala de outra pesquisadora que fica expressa a vontade e o esforço realizado pela equipe em simplificar a linguagem, em se fazer entender, sobrepondo a propaganda à publicidade:

(...) eu consigo falar complicado, (...) mas a gente acaba sempre querendo simplificar, querendo que as pessoas entendam aquilo que a gente está falando, e passar a informação do melhor jeito possível, para que a pessoa sinta que aquilo é bacana, para que as pessoas tenham interesse (E4).

\section{1. 4. Questionários realizados com os jornalistas}

De acordo com os critérios expostos, foram contatados 34 jornalistas de 24 diferentes veículos de comunicação - jornais, revistas, redes de rádio e televisão e sítios de jornalismo da Worldwide Web. Destes, 19 jornalistas de 16 diferentes veículos de comunicação responderam ao questionário.

Entre os 19 jornalistas participantes deste estudo, 14 (73,68\%) apontam traduzir a linguagem como o papel- ou um dos papéis - do jornalista nas relações com a ciência e/ou percebem a sua responsabilidade como a de divulgador das pesquisas científicas. Em duas respostas (J5 e J11) esta questão é apontada mesmo com um dever a ser cumprido pelos jornalistas. Apenas um deles demonstra entender-se como um representante da sociedade em relação à ciência ao aprofundar essa afirmação e considerar a transmissão da informação também um direito da mídia, a ser exercido com o intuito de transpor as barreiras entre a academia e os demais membros da sociedade. "A imprensa tem o dever e o direito de passar essas informações para a sociedade. A ciência não pode ficar reclusa apenas aos meios acadêmicos"(J5). 
Como contraponto à idéia de que o meio científico seja um setor à parte da sociedade, uma das respostas abaliza o trabalho do jornalista como complementar ao do cientista, entendendo a divulgação como parte de um ciclo que, para ser fechado, necessita de todos os seus agentes: cientistasmídia-sociedade:

Os pesquisadores em seus laboratórios fazem a ciência propriamente dita, mas o processo não está completo sem a mediação do jornalista (...) o trabalho do jornalista é a parte posterior indispensável do fazer científico - na medida em que sem divulgação o ciclo não se completa (J19).

A idéia de uma função talvez um pouco mais passiva, a de mediador entre ciência e sociedade surge em 04 (21,05\%) das respostas, sendo que um deles entende "divulgar" e "mediar" como sinônimos: "O jornalista (...) divulga a ciência, faz uma mediação entre o conhecimento acadêmico (...) e a população leiga" (J4), e outros dois acrescentam "traduzir a linguagem" ao papel de "mediar" (J5), "servir de porta-voz e tradutor dessas informações" (J15).

"Despertar o interesse pela ciência e motivar discussões éticas na sociedade" (J17) são colocações que aparecem uma única vez. Quando questionados em como ocorre a relação jornalista/mídia com o cientista apenas um profissional não aponta conflitos nesta relação, mesmo assim, colocado de forma pessoal "toda a vez que procurei o meio acadêmico(...) fui bem sucedida, bem atendida" (J6). Todos os demais trazem indicadores de tensão dos mais variados.

Muitas foram as manifestações de desagrado apresentadas pelos jornalistas em suas relações com os cientistas. As principais queixas dos 
jornalistas indicam um fato interessante: estes avaliam que os cientistas sentem-se em posição de superioridade ou privilegiada em relação aos profissionais da mídia. Ao relatarem dificuldade de acesso, espera excessiva para a entrevista, falta de paciência por parte dos cientistas, ou mesmo ao qualificarem os cientistas como arrogantes e herméticos, parecem indicar que percebem esta relação em claro desequilíbrio, onde o cientista se entende ocupando um lugar de destaque, por saber mais, conhecer melhor o assunto tratado.

Onze dos jornalistas entrevistados no presente estudo levantam diferentes questões nas quais os cientistas são indicados como os responsáveis por estas dificuldades. Emergem, aqui, diferentes problemas. Entre eles destacam-se a linguagem utilizada "as informações passadas geralmente são técnicas demais e de difícil compreensão" (J14), "não é à toa que é muito melhor conversar com um professor do que com um cientista sem experiência didática" (J16) e a dificuldade de acesso da mídia ao cientista, também citada por 04 entrevistados.

A desconfiança da academia em relação à imprensa surge em três entrevistas "demonstram certo receio com possível "manipulação" das informações prestadas" (J13). Um deles inclui, neste caso, a pouca abertura dos cientistas a outras opiniões como um fator diretamente ligado a esta desconfiança classificando os cientistas como "temerosos da mídia e apegados a opiniões restritas" (J17).

Aspectos ligados mais diretamente às características pessoais dos cientistas também apareceram em 02 respostas distintas e referem-se à 
paciência - "nem sempre (...) possui tempo e demonstra paciência para esclarecer todas as dúvidas" (J7) - e às atitudes pouco simpáticas dos pesquisadores "o jornalista sai frustrado com a arrogância e hermetismo do cientista" (J18).

Esta demonstração de consternação do jornalista em relação ao cientista - quando faz referência à frustração motivada por seu entrevistado é acompanhada por outro profissional da mídia ao declarar que "cientistas parecem julgar o trabalho jornalístico diário como superficial” (J15).

Apesar de serem citados em menor número, alguns sugerem que os jornalistas contribuem para a manutenção das dificuldades de suas relações profissionais com os cientistas.

Aqui são apontadas a falta de preparo para as entrevistas "vão para as entrevistas sem saber quase nada sobre o assunto" (J11), a necessidade de se adequar ao veículo de informação ao qual está a serviço "temos de escrever de acordo com o que a redação quer" (J2) e mesmo a dificuldade de entendimento do processo científico.

Um dos jornalistas, que teceu críticas a ambas as categorias de profissionais, finaliza com a frase "o resultado disso são as reportagens confusas e imprecisas que você encontra em toda a mídia"(J11).

Após estas análises quanto à inserção do LPAE junto à mídia não acadêmica, analisaremos a proposta de alcance ao público não acadêmico a partir das atividades deste Laboratório junto ao ensino formal básico, menos abrangente, porém, mais aprofundado e sistemático, quando comparado ao alcance propiciado pela mídia. 


\section{2. LPAE e a promoção de Educação Ambiental}

\section{2. 1. Projeto Coração Roxo}

Em junho de 2007, o Projeto Coração Roxo encontrava-se em seu 6ํำ ano de desenvolvimento.

Visto que será amplamente analisado pela Prof ${ }^{\mathrm{a}}$. Campina, nos abstemos aqui de aprofundarmos sua análise e discussão, apresentando apenas alguns dados que consideramos necessários ao presente trabalho.

No presente momento continua em andamento na EE José da Costa, no município de Cubatão (SP), contanto com a participação de 15 alunos. Estes realizaram, conforme a programação inicial, o mapeamento das principais regiões atingidas pela poluição atmosférica na cidade de Cubatão e posterior análise do ar destes locais através do teste de micronúcleo (TRAD-MNC).

Também foi realizada, em 2007, a apresentação do projeto à comunidade. Este evento aconteceu no Centro de Convenções da Prefeitura Municipal de Cubatão e contou com a participação tanto de alunos e professores das redes públicas de ensino como de pesquisadores do LPAE e autoridades locais.

Este Projeto, previsto para ter continuidade até 2008, também pretende analisar a água do rio Cubatão, utilizando-se da mesma técnica, bem como manter a divulgação de seus resultados à comunidade. 


\section{2. 2. Projeto Estação Ambiência}

5. 2. 2. 1. Curso "Poluição E Saúde - Projetos Ambientais e a Escola

Através do formulário "perfil do professor" (Anexo E1) preenchido por todos os 26 participantes presentes na abertura, podemos ter uma idéia das principais características dos profissionais que se interessaram em participar do curso, conforme mostra a tabela abaixo:

Tabela 2 - Distribuição dos professores de acordo com a série em que lecionam e a disciplina

\begin{tabular}{|c|c|c|}
\hline Perfil do Professor & Número & $\%$ \\
\hline Séries em que lecionam & & \\
\hline a. Ensino Fundamental & 22 & 84,61 \\
\hline - $1^{\mathrm{a}}$ a 4⿳亠口了 séries & 06 & 23,07 \\
\hline - $5^{\mathrm{a}}$ a $8^{\mathrm{a}}$ séries & 16 & 61,53 \\
\hline - 3. Exclusivamente $5^{\mathrm{a}}$ a $8^{\mathrm{a}}$ séries & 06 & 23,07 \\
\hline b. Ensino Médio & 12 & 46,15 \\
\hline - Exclusivamente & 02 & 7,69 \\
\hline $\begin{array}{l}\text { c. Núcleo de Educação Ambiental } \\
\text { Disciplinas que lecionam }\end{array}$ & 02 & 7,69 \\
\hline a. 5a a 8 séries & 16 & 61,53 \\
\hline - Ciências & 12 & 46,15 \\
\hline - Matemática & 03 & 11,53 \\
\hline - Geografia e História & 01 & 3,84 \\
\hline b. Ensino Médio & 12 & 46,15 \\
\hline - Biologia & 04 & 15,38 \\
\hline - Matemática & 03 & 11,53 \\
\hline - Química (exclusivamente) & 02 & 7,69 \\
\hline - Química, Física e Meio Ambiente & 01 & 3,84 \\
\hline - Sociologia & 01 & 3,84 \\
\hline - Inglês & 01 & 3,84 \\
\hline c. Núcleo de Educação Ambiental & 02 & 7,69 \\
\hline - Educação Ambiental & 02 & 7,69 \\
\hline
\end{tabular}

Dos 27 professores inscritos, 04 estiveram presentes apenas no primeiro encontro, sendo considerados desistentes. Os demais 23 
participantes permaneceram com, pelo menos, $60 \%$ de freqüência e média diária de assiduidade de 85,50\%.

De acordo com as avaliações realizadas no $5^{\circ}$ encontro e ao final do curso, houve boa aceitação por parte dos professores participantes. Nesta última avaliação, foi solicitado que relacionassem os pontos positivos e negativos do curso e que apresentassem sugestões para próximos eventos.

Dos 17 participantes que preencheram a avaliação no último encontro, $09(52,94 \%)$ incluíram entre os pontos positivos a qualidade das aulas/ professores palestrantes, 08 (47,05\%) deles referiram-se à ampliação do próprio conhecimento e $02(11,76 \%)$ à visita ao LPAE.

Como pontos negativos, $04(23,52 \%)$ referiram-se à dificuldade de participar sem terem sido dispensados das aulas que ministram, assumindo prejuízos financeiros e funcionais. Interessante notar que, apesar de terem sido feitos vários comentários sobre as dimensões, equipe e equipamentos do LPAE nos encontros que antecederam a ida à FMUSP, 03 professores $(17,64 \%)$ consideraram a visitação frustrante ou pouco produtiva. Os demais apontaram, individualmente $(5,88 \%)$, para problemas de ordem organizacional, como pouco tempo de curso, atrasos, falta de material para acompanhamento das apresentações ou mesmo a distância até sua escola.

Um deles (5,88\%) faz referência à qualidade das aulas, tendo considerado algumas repetitivas e outras com de tempo exposição muito longo. 
Vários comentários e algumas sugestões foram feitas, porém cabe destacar as manifestações de 08 (47,05\%) participantes relacionadas ao desejo de continuidade das atividades, seja de forma individual: "estou muito a fim de levar o projeto até conseguirmos resultados tão bons quanto o curso" ou coletivamente, através de propostas como manter reuniões constantes com os grupos para acompanhar os projetos e discutir encaminhamentos.

Com exceção de uma professora, que em 2007 não se manteria no cargo, todos os demais participaram ativamente da elaboração de projetos a serem desenvolvidos em suas escolas a partir das possibilidades apresentadas pelo LPAE e discutidas com os cientistas presentes no curso (Anexo D).

\section{2. 2. 2. Supervisão e Acompanhamento}

Durante o período de outubro de 2006 a junho de 2007 foi realizada a supervisão e o acompanhamento dos professores que participaram do curso PoSPAE. A seguir, alguns resultados que consideramos relevantes.

Dos 23 professores que participaram do curso PoSPAE, $10(43,47 \%)$ retomaram quando da primeira reunião de acompanhamento.

Destes, $08(34,78 \%)$ compareceram a pelo menos uma reunião seguinte, sendo que os números de alunos envolvidos são demonstrados na Tabela 3: 
Tabela 3 - Número de alunos participantes do projeto Estação Ambiência de acordo com a instituição de ensino de origem

\begin{tabular}{|c|c|c|}
\hline INSTITUIÇÃO DE ENSINO & SERIE/CURSO & $\mathbf{N} \mathbf{A}^{1}$ \\
\hline NEA-Cubatão & $\begin{array}{l}\text { Educação Ambiental } \\
\text { (estagiários) }\end{array}$ & 18 \\
\hline EE Afonso Schmidt (Cubatão/SP) & Ensino Médio & 20 \\
\hline EMEF Martim Afonso (Cubatão/SP) & $\begin{array}{l}8^{\text {a }} \text { série do Ensino } \\
\text { Fundamental }\end{array}$ & 07 \\
\hline Colégio Positivus (Santos/SP) & $\begin{array}{c}\text { Curso Técnico em Meio } \\
\text { Ambiente }\end{array}$ & 10 \\
\hline $\begin{array}{l}\text { EE Parque das Bandeiras - Gleba } \\
\text { II (São Vicente/SP) }\end{array}$ & $\begin{array}{c}7^{\text {a }} \text { e } 8^{\mathrm{a}} \text { séries do Ensino } \\
\text { Fundamental }\end{array}$ & 20 \\
\hline $\begin{array}{l}\text { Projeto Coração Roxo } \\
\text { (Cubatão/SP) }\end{array}$ & Ensino Médio & 08 \\
\hline EM Primeiro de Maio (Guarujá/SP) & $\begin{array}{l}\text { Curso Técnico em Meio } \\
\text { Ambiente }\end{array}$ & 82 \\
\hline Total & & 165 \\
\hline
\end{tabular}

${ }^{\mathrm{T}} \mathrm{NA}-\mathrm{n}^{\mathrm{o}}$. de alunos presentes nas reuniões de apresentação da pesquisa EEPRBS - Estuário

Em junho de 2007 a pesquisa encontrava-se em fase de aplicação de questionários. Entre os 165 alunos presentes nas três apresentações realizadas, 21 deles (12,72\%), provenientes do NEA-Cubatão, da EM Primeiro de Maio, da EE Parque das Bandeiras e do projeto Coração Roxo haviam se engajado até esta etapa do projeto. Outros aguardavam as próximas.

Entre os três professores que participaram, com seus alunos, das atividades da pesquisa EEPRBS - Estuário, um deles solicitou apoio do LPAE para realizar atividades de biomonitoramento, utilizando-se da técnica de micronúcleo da Tradescantia (TRAD-MNC), na EMEF Luiz Pieruzzi Netto em Cubatão. Foi viabilizado, através do LPAE, a compra de vasos e terra 
para o plantio das mudas. Devido à necessidade de inflorescências, que não ocorreram até o presente momento, aguarda-se a possibilidade de prosseguimento.

As professoras responsáveis pelo NEA-Cubatão também manifestaram interesse em desenvolver atividades de biomonitoramento a partir da análise de fungos em cascas de árvores, técnica citada durante o curso PoSPAE. Por recomendação do chefe do LPAE, foi contatada, através desta autora, a Profa ${ }^{\text {. Dra }}$. Mitiko Saiki, do Instituto de Pesquisas Energéticas e Nucleares (IPEN) da USP. Esta se interessou pela proposta e disponibilizou-se a conhecer o NEA-Cubatão para avaliar possibilidades de estudos na área. A equipe do NEA-Cubatão e a Profạ. Saiki corresponderam-se por correio eletrônico e conversaram por telefone mas, até o momento, não houve continuidade

Duas professoras que participaram do curso PoSPAE solicitaram

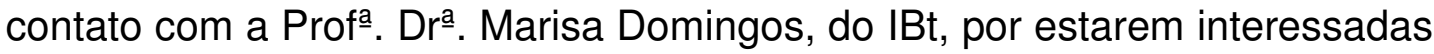
em desenvolver trabalhos de biomonitoramento de Ozônio. A Prof ${ }^{\mathrm{a}}$. Marisa indicou uma cientista do LPAE, que trabalha com este tipo de biomonitoramento, e que tem mantido contato com as professoras de Ensino Básico na tentativa de auxiliá-las. Até junho de 2007 o projeto ainda não havia se iniciado. 


\section{CAPÍTULO 6: DISCUSSÃO}

De que vale a pesquisa desenvolvida (...) se ela não levar o homem comum a melhorar sua qualidade de vida?

Núcleo José Reis de Divulgação Científica ${ }^{\text {XXVII }}$

\subsection{A CPC praticada pelo LPAE através da mídia}

Para que a análise das ações de divulgação dos conhecimentos realizadas pelo LPAE voltadas para a população não acadêmica possa levar a uma contribuição do aprimoramento na qualidade da Comunicação Pública da Ciência, propomos, inicialmente, uma contextualização teórica, de forma a possibilitar o clareamento desta discussão.

Em todo o corpo deste trabalho separamos as iniciativas de CPC efetuadas pelo LPAE entre a realizada pela mídia e as que ocorrem através das escolas, inclusive quanto aos procedimentos de coleta de dados. Isso porque, mesmo antes do início da pesquisa já nos parecia evidente, ainda que empiricamente, estarmos frente a estas duas propostas de CPC que, apesar de estarem intrinsecamente ligadas, apresentam-se com contornos bastante distintos. Novamente fazendo uso das palavras de Van der Auweraert, diferentes propostas convivem e interagem sendo "todas 
importantes para construir uma relação sustentável entre ciência e tecnologia'39 e entre estas e a sociedade.

Passamos, agora, ao processo de análise das falas e das ações dos cientistas do LPAE utilizando as categorias constantes no Capítulo 3:

- Modelo de déficit;

- Modelo contextual;

- Modelo de experiência leiga

- Modelo de participação pública.

A opção de realizar-se a análise à luz destas categorias baseou-se no entendimento de que, a nosso ver, estes quatro modelos destacam-se entre os que foram propostos até então por espelharem, de forma sintética e clara, as diferentes formas de CPC que ocorrem na atualidade.

Ao levantarmos algumas colocações feitas pelos cientistas, obtidas por meio das entrevistas, podemos perceber que a CPC realizada pelo LPAE oscila entre diferentes modelos. Vejamos estes exemplos:

Se tem alguma contribuição prática? Acho que, principalmente, a conscientização, quer dizer, é um problema de saúde pública, hoje, que a gente enfrenta e eu acho que a população tem que tomar conhecimento desse problema (E5).

(...) qual seria o impacto na melhoria da saúde? (...) eu acho que é esse tipo de informação que a gente tem que mostrar para a mídia leiga (E14).

Os jornalistas (...) transmitem o que de pesquisa de ponta a gente está desenvolvendo aqui, que é do interesse de todo paulistano e dos brasileiros (E2). 
Dentro destas falas, alguns tópicos nos chamam a atenção, quais sejam: "é do interesse de todos os paulistanos e brasileiros", "eu acho que a população tem que tomar conhecimento desse problema" e "é esse tipo de informação que a gente tem que mostrar para a mídia leiga". Através deles pode-se perceber que alguns cientistas entendem que cabe a eles a decisão sobre o que o público deva ou se interessa em saber. Em outros momentos, observa-se que alguns mantêm-se centrados na informação e na produção de conhecimento - e não na interlocução entre acadêmicos e não acadêmicos, no sentido de considerar o que o público quer saber sobre esses temas:

(...) levar isso para a sociedade e tentar fazer com que aqueles dados que você esteja gerando sirva para que a sociedade seja modificada de alguma forma (E14).

(...) estudos do laboratório tem contribuído, de certa forma, para uma postura diferente, não só dos órgãos públicos, sobre o controle da emissão de poluentes (...), mas tem conscientizado a população leiga também, no sentido de que a população também tem uma parcela de responsabilidade (E5).

(o LPAE) é um lugar onde se produz conhecimento e esse conhecimento precisa ser passado para a sociedade, a fim de que haja um retorno desse conhecimento (E11).

Entre os modelos referenciados neste estudo, as citações acima se mostram em consonância com o modelo de déficit pois, como já vimos, segundo Miller $^{33}$, entre as principais características deste modelo estão: a comunicação que ocorre a partir dos cientistas para o público, pressupondo- 
se que os primeiros sabem - e são capazes de satisfazer - as necessidades dos segundos em relação aos conhecimentos científicos; processo de comunicação centrado na informação e na produção/produtor do conhecimento e não na interlocução entre cientistas e não cientistas.

No entanto, não podemos deixar de considerar idéias manifestadas entre os cientistas entrevistados que não se enquadram no modelo de déficit. Como que exercendo um contraponto aos seus colegas, podemos observar em algumas declarações, como as destacadas abaixo, cientistas do LPAE preocupados em promover um maior intercâmbio entre cientistas e não cientistas.

Eu acho que qualquer laboratório de pesquisa tem que estar atento aos problemas mais gritantes, mais emergentes da sociedade e, de uma forma ou de outra, com recurso ou sem recurso, correr atrás de responder, de dar uma resposta a estas perguntas, a estas questões. E, nesse sentido, eu acho que nós temos cumprido bem esse papel (E10).

(as informações produzidas pelo LPAE) Podem ser, não só transmitidas, mas discutidas com alguns setores que possam compreender essa informação, para transmitir essa informação para as comunidades. (...) Essas discussões, elas tem que passar pelo o que fazer para diminuir essa exposição (à poluição), ou quais são as estratégias que você tem na comunidade para se proteger em relação a isso (E7).

Estes cientistas apontam para uma preocupação com o que a população não acadêmica considera como "problemas mais gritantes" e mesmo em discutir mais diretamente com "alguns setores da sociedade que 
possam compreender essa informação". Estas falas se mostram mais adequadas ao modelo de participação pública, uma vez que este modelo propõe uma maior constância no diálogo entre cientistas e não cientistas e pressupõe uma melhor compreensão da dimensão cultural na qual a ciência encontra-se imersa ${ }^{32}$. Além disso, ao afirmar “(...) quais são as estratégias que você tem na comunidade para se proteger em relação a isso" este pesquisador está levando em conta que a própria comunidade possui conhecimentos que devem ser considerados ao trabalhar com as questões ligadas a poluição ambiental. Nesse caso, encontramos aqui indícios do modelo da experiência leiga, o qual aposta na importância de valorar das experiências e dos conhecimentos de grupos e comunidades - saberes esses considerados não científicos - na relação entre a ciência e a sociedade.

Entre os entrevistados foi possível identificar quem se questione se a divulgação deveria ocorrer da mesma forma para qualquer público, o que parece sublinhar a percepção de que existem diferentes públicos, logo diferentes interesses com relação à ciência e tecnologia. Esses aspecto se aproxima das discussões mais atuais sobre CPC na medida em que o público não é mais entendido com uma massa uniforme, mas sim detentor de conhecimentos, vontades e interesses quanto a assuntos de Ciência e Tecnologia. O exemplo a seguir se refere a essa questão:

(...) a informação é sempre boa para qualquer pessoa, mas existem algumas informações, de alguns trabalhos científicos, que interessam e que seriam melhor aproveitados a um público alvo que na verdade seriam médicos e pacientes, os tratados e quem vai 
tratar. (...) então, quem é que vai aproveitar? Ele (o público não acadêmico) vai ser beneficiado com essa informação, com esse estudo, mas quem é que vai aproveitar? Quem é que vai praticar isso? Quem é que vai tirar proveito e aplicar isso? Não é ele na verdade, então eu não sei se é bom (...) (E9).

A partir da análise realizada é possível afirmar que não há uma única direção ou modelo no que se refere à política de CPC no LPAE, o que faz com que despontem diferentes posturas de seus representantes nos seus relacionamentos com a mídia.

\subsection{A CPC praticada pelo LPAE através das escolas}

Para que possamos partir para a análise da CPC realizada pelo LPAE via escolas, algumas observações preliminares se fazem necessárias.

Ambos os projetos analisados acontecem dentro da escola formal. $O$ projeto Coração Roxo é realizado diretamente e apenas com alunos regularmente matriculados no Ensino Médio e, com exceção das saídas a campo para coleta de material ou de dados, todos os encontros entre a pesquisadora do LPAE e os educandos aconteceram no espaço escolar. Já no Projeto Estação Ambiência, o curso PoSPAE foi oferecido exclusivamente a professores em exercício nas redes públicas de ensino e todas as propostas de continuidade realizadas por estes professores durante o curso foram elaboradas de forma a ocorrerem dentro de suas escolas.

É natural e mesmo esperado que as atividades dos Projetos aqui analisados tenham sido permeadas pelas características próprias do contexto escolar. Entre elas, podemos ressaltar a proximidade física e a periodicidade regular em que se estabelece a relação educador/educando 
dentro das normas da escola formal, bem diversa por exemplo da que o jornalista ou o divulgador de ciência tem com seu público.

Importante ressaltar que algumas idéias que popularizaram-se no Brasil a partir de Paulo Freire ${ }^{8}$ e hoje são apontadas, nas maiorias das discussões que se realizam nesta área, como conceitos básicos de educação, também podem ser observadas nos Projetos analisados, como o exercício constante do diálogo entre educador e educandos e o respeito pelas características específicas de cada comunidade. Em relação à manutenção do diálogo, tanto no Coração Roxo como no Estação Ambiência, as propostas apresentadas pelos cientistas aos educandos/professores estavam abertas à sugestões, tendo sido realizados replanejamentos no decorrer dos processos como conseqüência desta relação. Como exemplos, podemos citar a visita realizada pelos professores ao LPAE no curso PoSPAE ou a parceria estabelecida com o Projeto EEPRBS - Estuário, ambos não previstos no início das atividades e realizados a partir de discussões entre os cientistas e não cientistas.

Quanto à questão do respeito pelas características e interesses do público-alvo nas duas experiências, citamos como exemplo o fato de o curso PoSPAE ter deixado a critério dos professores de ensino Básico a escolha, entre as atividades desenvolvidas pelo LPAE, por aquelas que melhor correspondessem ao que cada um considerava como de maior relevância para suas respectivas comunidades escolares.

Entretanto, apesar das ações acima analisadas apresentarem proximidades importantes com a educação formal, há especificidades que, 
ao serem consideradas, rompem com a lógica da estrutura formal de ensino e as aproximam das características da Comunicação Pública da Ciência.

Como exemplo, podemos citar o fato de as atividades teóricas e práticas desenvolvidas pelo Projeto Coração Roxo terem acontecido à parte dos conteúdos formais uma vez que nenhuma destas atividades foi incluída nos planejamentos anuais dos professores da escola onde acontece o Projeto. Além disso, foram realizadas fora do horário regular do aluno, desenvolvidas por uma profissional representante de outra instituição que não a escola e a participação foi opcional, desvinculada de atribuição de conceitos ou obrigatoriedade de freqüência.

Já o Projeto Estação Ambiência trazia entre seus objetivos, desde seu princípio, o de divulgação dos trabalhos científicos realizados pelo LPAE através de atividades que pudessem subsidiar professores de Ensino Básico a trabalharem, através de projetos, com conceitos e pesquisas desenvolvidos.

Reproduzimos abaixo as falas da chefia do LPAE de quando questionado, através das entrevistas, sobre o que o motivou a buscar parceria com o Ensino Básico e se entre os seus objetivos estaria alcançar o público não acadêmico:

(...) eu me lembro de todos os professores de Ciências que foram ruins (...). Então eu me lembro muito bem de como podia ter sido legal o ensino de Ciências se tivesse um jeito bom de fazer, como foi importante. É uma fase tão importante da formação, na definição da personalidade. Eu sou um professor (de Ensino Básico) encruado, eu já disse isso, e eu não consigo acreditar no ensino estruturado (...) 
(...) para resolver o problema, na nossa área tem que se basear em mudanças de comportamento, e aí você tem que transmitir esse conhecimento. Então a nossa idéia de atingir o grande público vem dessa necessidade.

Como pode ser observado, apesar da falta de "crença em um ensino estruturado" a busca por "um jeito bom de se ensinar Ciência" e a idéia de "atingir o grande público" a fim de promover "mudanças de comportamento" permitiram ao LPAE ir além de um processo de CPC realizado através da mídia. Todo um procedimento comunicativo de Ciência pôde acontecer através de uma parceria com a escola Básica e aqui identificamos interseções e articulações entre processos comunicativos e educativos os quais possuem objetivos e se utilizam de procedimentos que podem ser identificados com ambas as áreas de conhecimento.

Em vista do exposto e dentro da proposta de análise da CPC praticada pelo LPAE através das escolas utilizando as categorias já mencionadas, sugerimos uma variante do modelo de Participação Pública, o que consideramos como uma subcategoria, a ser aplicado particularmente aqui ou em outras situações com as mesmas peculiaridades. Caracterizamos essa ação dentro deste modelo, pois esse pressupõe a participação, em diferentes níveis, do público ao qual foi endereçada. Nesse modelo, entende-se que os participantes possuem interesses e conhecimentos que devem ser considerados em alguma medida na elaboração e/ou realização da ação, o que foi identificado em ambos os projetos. 
Nesses casos, contudo, a CPC se dá intermediada, necessariamente, por profissionais da área da educação e são desenvolvidas em contextos escolares, logo submetidos às especificidades de tempo, espaço e relações interpessoais desse local, o que nos leva a denominá-lo como Modelo de Participação Pública Educacional, No caso do Projeto Coração Roxo, a cientista responsável tem formação em pedagogia e mantêm contato direto com os alunos, desenvolvendo suas atividades na escola. Já no caso do Projeto Estação Ambiência a atividade ocorreu com professores de Ensino Básico que, ao participaram de curso PoSPAE puderam interferir nas ações planejadas.

Nestes casos identificamos a possibilidade do desenvolvimento da CPC com a parcela da população que se encontra inserida na escola formal. Como dissemos anteriormente, no que se refere às relações entre ciência, tecnologia e sociedade, os diferentes modelos de CPC podem ocorrer, mesmo concomitantemente, não apenas integrando-se, mas complementando-se. Além disso, como mostra a experiência com o Projeto Coração Roxo, em realização pelo LPAE, mesmo quando as ações de CPC possuem como espaço privilegiado o contexto escolar, estas podem ultrapassar os limites da escola, alcançando a comunidade através das atividades realizadas e mesmo dos alunos que se tornam agentes de divulgação do conhecimento científico. 


\subsection{A CPC sob a ótica de quem faz e de quem divulga ciência.}

Através dos relatos, observa-se que a equipe do LPAE alcançou certa maturidade em termos de pesquisa ao considerar que a solução para os problemas ambientais constatados nos resultados dos seus estudos passa por questões extremamente amplas, como vontade política e mudança de comportamento, fatos por eles considerados factíveis, desde que o conhecimento produzido alcance a população.

A partir destas entrevistas, foi possível observar, também, que há consenso no entendimento de o LPAE ser um local de produção científica importante, com boa inserção na comunidade científica - nacional e internacional.

Esta questão é discutida por $\operatorname{Diaz}^{27}$ ao analisar os motivos de se fazer ciência para não cientistas. Nesta análise, são detectados motivos altruístas e perversos. No primeiro caso, "de se fazer partícipes os demais dessa espécie de nirvana que proporciona contemplar as maravilhas e curiosidades da natureza e ter descrições satisfatórias de como funciona o mundo".

Em contrapartida, há também motivos por ele qualificados de perversos, como a necessidade de se fazer propaganda para manter-se o prestígio e os conseqüentes financiamentos da ciência.

Pode-se argumentar que, como no caso dos cientistas do LPAE, os cientistas apresentem certa resistência em fazerem referência aos considerados "motivos perversos". Importante, e mais realista, é considerar 
que um motivo não invalida o outro e que ambos, motivos altruístas ou perversos, podem estar presentes, variando apenas o grau de intensidade em que um se sobrepõe ao outro, de acordo com as diferentes pessoas que compõem os diferentes grupos de cientistas.

A percepção de divulgação pela imprensa não acadêmica é bastante discordante entre o grupo. Aqueles que entendem que esta divulgação é boa ou razoável apontam como justificativas para esta percepção os fatos de considerarem a chefia uma pessoa popular, capaz de extrapolar o meio acadêmico e o de entenderem que o tema "poluição" é de interesse geral da população. Por outro lado, observa-se certa insatisfação manifesta por alguns, indicando que gostariam que essa inserção fosse mais expressiva.

Uma manifestação importante é, também, a que expressa o desejo da equipe que seus trabalhos sejam capazes de influenciar decisões políticas e venham a beneficiar a população de forma abrangente e definitiva.

Uma sugestão apresentada por um dos cientistas e que seria uma alternativa viável na busca de uma maior popularização das pesquisas realizadas no LPAE é a contratação de um assessor de comunicação, comprometido com a divulgação mais acurada e constante dos trabalhos desenvolvidos pelo Laboratório.

Pesquisas realizadas na Alemanha por Krüger ${ }^{X X X V I I I}$ e Peters e Krüger $^{\text {XXXIX }}$ apud Peters ${ }^{64}$ mostram que $91 \%$ dos cientistas entrevistados

XXXVIII Krüger J. Wissenschaftsberinchterstattung in Aktuellen Massenmedien aus der Sicht dier Wissenschaftler. In: Flöhl R; Fricke J (eds) Moral und Verantwortung in der Wissenschaftsvermittlung: Die Aufgaben von Wissenschaftler und Journalist. Mainz: von Hase \& Köler, 1987. 
concordavam que "na ciência é obrigatório se envolver ativamente na transferência de conhecimento para o público" (grifo nosso).

Cidoval $^{65}$, ao fazer uma revisão da literatura em relação aos trabalhos que exploram a questão da divulgação científica no Brasil, indica a constância com que surgem as tensões entre cientistas e divulgadores: "jornalistas (divulgadores de Ciência de uma forma geral) e cientistas, em muitos trabalhos, foram colocados de lados opostos, protagonizando conflitos, tensões, numa relação desgastante e pouco produtiva”.

Em recente pesquisa sobre a percepção pública da Ciência e Tecnologia realizada em todo Brasil pelo Ministério da Ciência e Tecnologia $^{66}$, entre os entrevistados que declararam não ter interesse em Ciência e Tecnologia, 37\% apontaram como a principal razão a dificuldade de compreensão. Muitas críticas têm sido feitas em relação à transposição da linguagem científica para saberes comuns, incluindo o uso de termos como distorção e simplificação, indicando que alguns consideram exageros nas alterações, de forma a comprometer o conteúdo original ${ }^{67}$.

Como qualquer núcleo de pesquisa, o LPAE se utiliza de um vocabulário que é pouco familiar não só para o público não acadêmico, mas até mesmo para pesquisadores de outras áreas do conhecimento. Naturalmente esta é uma questão importante quando se pretende a comunicação através da mídia não acadêmica. Uma entrevista ou reportagem pode tornar-se "vazia" se não for capaz de levar alguma

XxxIX Peters HP; Krüger J. Der Transfer wissenschaftlichen Wissens in die Öffentlichkeit aus der Sicht von Wissenschaftlern. Ergebnisse einer Befragung der wissenschaftlichen Mitarbeiter der Kerfornschungsanlage Jülich. Jülich: Kerfornschungsanlage Jülich, 1985. 
informação minimamente compreensível a quem se destina e servir apenas e tão somente de publicidade - na acepção já discutida anteriormente - ou ainda transmitir idéias e/ou conceitos confusos e até mesmo errados do ponto de vista técnico.

Ao analisarmos as relações entre jornalistas e cientistas, observamos importantes pontos de conflitos. A equipe de cientistas aqui representada traz questões já levantadas por outros colegas (Peters, 2005) ${ }^{66}$ como a falta de preparo dos jornalistas, e o que pode ser considerado como uma deturpação das entrevistas concedidas. Apesar de surgir uma autocrítica em algumas falas, como sendo o cuidado com a escolha das palavras algo que compete ao cientista, há também quem se demonstre insatisfeito com a postura dos jornalistas. Estes, por sua vez, entendem seu principal papel como o de divulgador da ciência, onde está incluída a função de "tradutor da linguagem", apresentando os fatos de acordo com o que considera adequado ao público ao qual se direciona, ainda que essa adequação não seja plenamente aceita pelos cientistas.

A noção de "direito de acesso às informações científicas" apresentada por um dos jornalistas é, sem dúvida, um ponto crucial. Em uma sociedade democrática como a que pretendemos não pode haver espaço para segredos científicos, e o que estes podem representar para as relações de poder. 


\subsection{O LPAE e a realização da CPC de Participação Pública}

\section{Educacional}

Quando comparamos os objetivos propostos e os objetivos alcançados entre as duas ações aqui analisadas de parceria do LPAE com escolas de Ensino Básico, observa-se uma grande discrepância.

No caso do Projeto Coração Roxo, entendemos que esta pode ser considerada como uma das experiências mais bem sucedidas do LPAE em Educação Ambiental e em CPC de Participação Pública Educacional. Mantido ao longo dos últimos seis anos e ainda em atividade, vem alcançando educadores, educandos e comunidade de uma forma dialógica e constante.

Perrenoud $^{68}$ ao avaliar seminários de pesquisas realizados por estudantes de Ensino Básico aborda a importância tanto da concepção como da condução do processo. Este autor nos diz:

Enquanto se formar os estudantes para a pesquisa fazendo-os recolher e sistematizar dados em função de hipóteses de pesquisa para cuja definição eles não contribuíram, se manterá a ilusão de que se forma pesquisadores quando, na verdade, se treina técnicos.

O Projeto Coração Roxo não tem entre os seus objetivos formar pesquisadores, mas todo ele só pôde acontecer a partir do entendimento e desenvolvimento de metodologias de pesquisa por parte dos alunos. Bem diferente de "treinar técnicos", o Projeto tem se mostrado capaz de promover estímulos aos estudantes para que estes mantenham-se participativos e atuantes. 
O Projeto Estação Ambiência apresentou, no curso PoSPAE, uma série de pontos positivos quando analisado não só sob a ótica do modelo de CPC mencionado como mostra-se em consonância com diversos e atuais teóricos da área de formação de professores.

Entre outros, podemos citar Tristão ${ }^{52}$ que entende que a formação de professores, mais especificamente ligada à educação ambiental, deve dialogar com outros contextos de formação, "estabelecer elos como mola mestra da tecitura da formação e ficar alerta para as diferentes formas de relações entre conhecimento acadêmico/senso comum, teoria/prática.”

Guimarães $^{48}$, ao analisar a formação de educadores ambientais, avalia que a produção teórica da educação ambiental brasileira, que vem se realizando pelo menos nos últimos 20 anos, se estrutura de forma a contestar a educação tradicional, denominada por Freire ${ }^{8}$ de "educação bancária”e já abordada neste trabalho.

Quintas $^{69}$ é outra referência que embasa a idéia de que os caminhos dialéticos trilhados pelos professores e cientistas no curso aqui discutido estão de acordo com as propostas de estudiosos atuais. Esta autora faz uma análise de cursos de formação de professores à luz das teorias de Vygostky, um dos mais conceituados teóricos na área de educação da atualidade. Ao abordar as possibilidades e o papel do profissional denominado por esta autora de capacitador e que, no caso do curso em discussão, trata-se do cientista do LPAE, Quintas ${ }^{69}$ nos fala: 
na fala externa entre os interlocutores como na fala interior daquele que (re)aprende pelo processo ativo de internalização

Porém, algumas dificuldades importantes também surgiram. A primeira delas que, para ser contornada, precisou contar com disponibilidade e investimento de tempo por parte da chefia do LPAE refere-se às negociações com a rede estadual de ensino.

São abundantes as discussões que se fazem na atualidade, tanto nos meios acadêmicos como fora dele, sobre órgãos públicos e suas extenuantes burocracias. Pedro Roberto $\mathrm{Jacobi}^{70}$, conceituado estudioso da área de educação e, em especial, Educação Ambiental, ao discutir a questão da participação na gestão pública dos recursos hídricos no Brasil, faz uma reflexão sobre a influência negativa da burocracia de nosso país sobre as relações entre órgãos governamentais e a sociedade como um todo:

(..) tensões e contradições entre representantes de governo e diferentes segmentos da sociedade (são) criadas tanto por excesso de burocracia e a complexidade de muitos procedimentos que desestimulam a participação dos cidadãos.

A Diretoria Regional de Ensino optou por não tomar a decisão de autorizar (ou não) a realização do curso, apesar de possuir autonomia para tal, encaminhando a solicitação para instâncias superiores. Foram necessários vários contatos telefônicos, envio de dados e reuniões para que a autorização fosse concedida, lembrando que esta ocorreu sem a dispensa de ponto dos professores, conforme solicitado inicialmente pelo LPAE. 
Além deste fato, a distância do local de realização do curso em relação às escolas localizadas em municípios vizinhos também foi um fator limitante. O número de inscritos foi considerado satisfatório demonstrando interesse despertado nas escolas pela proposta apresentada.

Pode-se concluir, tanto através da assiduidade mantida durante os 10 encontros como das avaliações realizadas durante e após o curso que o interesse foi mantido e as expectativas dos participantes contempladas.

A complexidade dos projetos elaborados é um claro indicador do desejo dos professores em levarem para suas escolas as informações recebidas e, consequentemente, divulgar nas suas comunidades escolares as pesquisas realizadas pelo LPAE.

No entanto, se o curso em si pode ser considerado como uma ação bem sucedida, já a continuidade proposta pelo Projeto Estação Ambiência foi conseguida quase que exclusivamente através do engajamento de poucos professores nas pesquisas do Projeto EEPRBS - Estuário.

Estas experiências apontam para a necessidade de um profissional, com experiência tanto em metodologia científica como em prática pedagógica, que possa fazer a intermediação entre o centro de pesquisa e as escolas. Como pôde ser observado no final do curso, havia uma expectativa unânime e vontade manifesta pelos professores em dar continuidade às atividades em parceria com o LPAE. Todos os cientistas que estiveram presentes deixaram formas de serem contatados e a chefia do LPAE se disponibilizou insistentemente em auxiliar no que fosse necessário 
para a manutenção dos projetos. Porém, com a impossibilidade de se manter a intermediação no período letivo subseqüente ao curso, nenhum dos projetos originais teve prosseguimento até o momento. No entanto, tanto no Projeto Coração Roxo como no Curso PoSPAE, ambos em que a intermediação pelo profissional educador/cientista se manteve ininterrupta, os objetivos iniciais foram e vêem sendo alcançados.

Outra questão que se apresenta é a importância de se promover e facilitar aproximação da universidade com as escolas de Ensino Básico. Como ficou claro, os profissionais de ambas as instituições estavam interessados no trabalho em conjunto. Entendemos que uma complexa rede de motivos deve ter contribuído para isto. Compreendê-los e apontá-los demanda em novos estudos, no entanto, com os dados obtidos por este estudo, observa-se que tanto universidade como as escolas tendem a se beneficiarem com esta parceria. A primeira através da Comunicação Pública de seus trabalhos, de suma importância e já exaustivamente discutida neste trabalho. Quanto às escolas, através do suporte e respaldo oferecido pela universidade nesta parceria e que pode servir como um auxiliar nos processos de ensino/aprendizagem. 


\section{CAPÍTULO 7: CONCLUSÃO}

Para entender a nós mesmos precisamos entender as estrelas. Nós somos poeira estelar - as cinzas das estrelas há muito mortas.

Martin Rees ${ }^{X L}$

astrofísico e cosmologista

Depois do exposto, apresentamos como sendo as principais conclusões e contribuições deste estudo:

- Um centro de pesquisa por excelência, como LPAE, é capaz de se manter na mídia não acadêmica constantemente;

- Concluímos que as comunicações realizadas através da mídia não acadêmica aqui analisadas oscilam entre os modelos de défict, de participação pública e de experiência leiga. Uma definição por parte da equipe de cientistas do LPAE de qual linha de CPC este grupo considera a mais interessante a seguir em seus contatos com a mídia evitaria, ou ao menos minimizaria, posições divergentes.

- Apesar de a literatura disponível apresentar algumas categorizações de CPC, propomos uma específica, que abranja de forma mais clara a

\footnotetext{
$\mathrm{XL}$ A ciência consegue responder a todas as perguntas? Tradução de Diogo Meyer e Suzana Couto. In: John B., Katina M., organizadores. As coisas são assim: pequeno repertório científico do mundo que nos cerca. São Paulo: Companhia das Letras; 1997.
} 
participação da escola formal básica como uma das intermediadoras do processo, aqui denominada de modelo de Participação Pública Educacional;

- Vários pontos de tensão emergiram nas declarações tanto de cientistas como de jornalistas permitindo uma avaliação das principais questões que permeias as relações entre cientistas, ligados à área da saúde e profissionais da mídia não acadêmica.

Da parte dos cientistas, a principal queixa refere-se ao despreparo dos jornalistas referente às questões científicas.

Muitas foram as manifestações de desagrado apresentadas pelos jornalistas em suas relações com os cientistas. As principais queixas dos jornalistas indicam que estes avaliam que os cientistas sentem-se em posição de superioridade ou privilegiada em relação aos profissionais da mídia, indicando que percebem uma falta de equilíbrio nesta relação pelo fato do cientista se entender ocupando uma posição de destaque.

- É possível e de interesse tanto de professores como de cientistas o intercâmbio de forma continuada entre os centros de produção científica e a escola básica. Porém a estruturação das redes públicas de ensino não estimula tal prática, dificultando a implantação ou continuidade de iniciativas deste porte. Para que se tornem viáveis, é necessário um profissional responsável pela intermediação do processo.

Aproximar produtores (cientistas) e divulgadores (jornalistas/professores) e encontrar o ponto mediador entre a linguagem científica, considerada por muitos como hermética, e a distorção dos fatos 
são os desafios que se nos apresentam. A divulgação da ciência é importante e fundamental, uma necessidade de nossa época. Para tanto, quanto maior o número de profissionais destas áreas que encontrem o equilíbrio em suas relações, mais acesso claro e seguro à ciência será permitido à população em geral. 


\section{ANEXOS}

\section{Anexo A}

\section{Perguntas que orientaram as entrevistas com os cientistas do LPAE}

1. Solicitar que caracterize o Laboratório:

a. Qual a importância do LPAE - é importante? Para quem e por quê?

b. Qual seu alcance no meio acadêmico nacional e internacional e entre a população não acadêmica em geral e/ou população específica?

2. Em sua opinião, quais os objetivos que um Laboratório como o LPAE deva cumprir?

3. Quanto à idéia de levar as informações - ou os resultados dos trabalhos produzidas no LPAE para um público não acadêmico, o que acha? Haveria condições de compreensão? Justificar.

4. Nas pesquisas que participa (ou participou), avalia que haveria alguma contribuição se o conhecimento dos resultados chegasse às pessoas fora da área científica? Quais?

5. Poderia citar experiências em que precisou passar informações referentes às suas pesquisas para o público não acadêmico? 


\section{Perguntas que orientaram a entrevista com o chefe do LPAE}

1. Caracterização o Laboratório:

a. o LPAE atende pela sigla LIM 05. Quando o Dr. György assumiu já existia o LIM 05 e ele instalou o LPAE?

b. Como o senhor definiria os propósitos do LPAE?

c. Quais as principais linhas de pesquisa?

d. Como está estruturado?

e. Qual a importância do LPAE - é importante? Para quem e por quê?

f. Qual seu alcance no meio acadêmico nacional e internacional e entre a população não acadêmica em geral e/ou população específica?

2. Pedir para falar sobre quando assumiu a chefia (em qual ano, em quais condições, impressões).

3. O LPAE nasceu a partir do interesse do Dr. György em trabalhar com a pesquisa pura. Isto se mantém? Na sua avaliação, o que foi mantido e o que foi modificado do período do Dr. György para o seu?

4. As disciplinas Informática Médica e Telemedicina, nascidas aqui no LPAE, fazem parte do currículo obrigatório de graduação da FMUSP?

a. a Telemedicina é uma conseqüência da Informática Médica?

5. São muito comuns as referências ao senhor como "inovador, que enxerga além, que está um passo à frente". Poderia citar trabalhos aqui do LPAE que, em sua opinião, poderiam ser considerados inovadores? 
6. Quais as pesquisas do LPAE que tiveram maior repercussão junto à comunidade científica?

7. E junto ao público não acadêmico?

8. Pedir que comente entrevistas concedidas a Jô Soares, Silvia Popovic, rádio Bandeirantes, etc. - solicitar que especifique os assuntos tratados.

9. Além da mídia, o LPAE tem algum outro canal de comunicação com o público não acadêmico?

10. O que o motivou a propor o desenvolvimento de pesquisas realizadas no laboratório em escolas de ensino básico?

a. Quando essa idéia surgiu?

b. Tem inspiração em outras experiências? Quais? 


\section{Anexo B}

\section{Questionário aplicado aos jornalistas}

1) Nas entrevistas e/ou reportagens que realizou com os pesquisadores do Laboratório de Poluição Atmosférica da Universidade de São Paulo (LPAE/USP), o que o motivou a procurar por este laboratório?

2) Quais eram suas expectativas quando agendou a entrevista?

3) Estas expectativas foram contempladas?

( ) Totalmente.

( ) Parcialmente. Por quê?

( ) Não foram contempladas. Por quê?

4) Você considera o LPAE/USP uma boa fonte para gerar matérias/reportagens que sejam de interesse da população?

5) Em relação à confiabilidade das informações obtidas através dos pesquisadores do LPAE referentes aos efeitos de poluição na saúde, você qualificaria como:

( ) Totalmente confiáveis

( ) Parcialmente confiáveis. Por quê?

( ) Não são confiáveis. Por quê? . 
6) Nas entrevistas/reportagens que realizou você considera a linguagem utilizada pelos pesquisadores do LPAE acessível ao público não acadêmico?

7) Em qual editoria do seu jornal são publicadas as matérias cuja fonte é o LPAE?

8) Em sua opinião, qual o papel do jornalista/mídia nas relações com a ciência?

9) Descreva como se dá, em sua opinião, a relação jornalista/mídia com o cientista:

a) Situação ideal:

b) Situação real:

10) Em relação aos objetivos de uma matéria/reportagem a ser veiculada pela mídia, você entende que:

c) os objetivos da mídia são:

d) os objetivos dos cientistas são: 


\section{Anexo C}

\section{Resumo do documento "Artigos de Divulgação do Laboratório de Poluição Atmosférica Experimental”}

\begin{tabular}{|c|c|c|c|}
\hline DATA & $\mathbf{V C}^{*}$ & TÍTULO & ASSUNTO \\
\hline $\begin{array}{l}1982 \\
09 / \text { jun }\end{array}$ & $\begin{array}{l}\text { Jornal O } \\
\text { Estado de } \\
\text { S.Paulo }\end{array}$ & $\begin{array}{l}\text { Número de } \\
\text { mortes é maior } \\
\text { com a poluição }\end{array}$ & $\begin{array}{l}\text { A partir de depoimento de Böhm refere- } \\
\text { se ao aumento de no. de mortes na } \\
\text { Capital (do Estado) como conseqüência } \\
\text { da poluição. }\end{array}$ \\
\hline 1985 & $\begin{array}{l}\text { Jornal do } \\
\text { Campus - } \\
\text { USP }\end{array}$ & $\begin{array}{l}\text { Falta de dinheiro } \\
\text { ameaça fechar } \\
\text { Laboratório }\end{array}$ & $\begin{array}{l}\text { A partir de depoimento de Saldiva trata } \\
\text { dos principais trabalhos do LPAE e a } \\
\text { possibilidade de fechamento. }\end{array}$ \\
\hline $\begin{array}{l}1985 \\
27 / \text { out }\end{array}$ & $\begin{array}{l}\text { Jornal } \\
\text { Shopping } \\
\text { News - } \\
\text { City News }\end{array}$ & $\begin{array}{l}\text { Regule seu } \\
\text { carro. No calor } \\
\text { ele é o vilão }\end{array}$ & $\begin{array}{lrr}\text { Trata dos poluentes emitidos } & \text { pelos } \\
\text { escapamentos dos carros e } & \text { suas } \\
\text { conseqüências para a saúde e } & \text { meio } \\
\text { ambiente. Traz depoimentos } & \text { de } \\
\text { engenheiro da CETESB e de Böhm } & \end{array}$ \\
\hline $\begin{array}{l}1985 \\
\text { dez }\end{array}$ & $\begin{array}{l}\text { Revista } \\
\text { Quatro } \\
\text { Rodas }\end{array}$ & $\begin{array}{l}\text { Uma briga pela } \\
\text { limpeza do ar }\end{array}$ & $\begin{array}{l}\text { Trata da discordância de opiniões entre } \\
\text { montadoras e técnicos em poluição do ar. } \\
\text { Traz foto de Böhm que discorre sobre o } \\
\text { trabalho do LPAE de toxicidade do álcool } \\
\text { e gasolina. }\end{array}$ \\
\hline ausente & ausente & $\begin{array}{l}\text { Convênio para } \\
\text { estudar efeitos } \\
\text { do fumo e } \\
\text { poluição }\end{array}$ & $\begin{array}{l}\text { A partir de depoimento de Saldiva trata } \\
\text { de pesquisa da FMUSP sobre o } \\
\text { tratamento preventivo de câncer } \\
\text { pulmonar para fumantes }\end{array}$ \\
\hline $\begin{array}{l}1986 \\
\text { ago }\end{array}$ & $\begin{array}{l}\text { Jornal } \\
\text { SaciXLI }\end{array}$ & $\begin{array}{l}\text { Mais uma } \\
\text { contribuição do } \\
\text { Proálcool }\end{array}$ & $\begin{array}{l}\text { Trata das vantagens do álcool como } \\
\text { combustível; Böhm discorre sobre o } \\
\text { trabalho do LPAE de toxicidade do álcool } \\
\text { e gasolina. }\end{array}$ \\
\hline $\begin{array}{l}1987 \\
12 / \mathrm{dez}\end{array}$ & $\begin{array}{l}\text { Jornal } \\
\text { Folha de } \\
\text { S.Paulo }\end{array}$ & $\begin{array}{l}\text { Pesquisa em } \\
\text { situação real } \\
\text { mostra efeitos } \\
\text { da poluição }\end{array}$ & $\begin{array}{l}\text { Matéria sobre o LPAE. Entrevista Saldiva; } \\
\text { cita pesquisa sobre toxicidade do álcool e } \\
\text { gasolina; discorre sobre pesquisa de } \\
\text { comparação de toxicidade industrial e } \\
\text { urbana. }\end{array}$ \\
\hline $\begin{array}{l}1988 \\
13 / \text { jul }\end{array}$ & $\begin{array}{l}\text { Jornal O } \\
\text { Estado de } \\
\text { S.Paulo }\end{array}$ & $\begin{array}{l}\text { Centro fecha } \\
\text { hoje para carros }\end{array}$ & $\begin{array}{l}\text { Trata da Operação Alerta } 2 \text { (simulação de } \\
\text { um dia sem circulação de carros no } \\
\text { centro de S.Paulo). A partir de } \\
\text { depoimento de Böhm, aborda a pesquisa } \\
\text { do LPAE de comparação dos poluentes } \\
\text { do álcool e gasolina, }\end{array}$ \\
\hline $\begin{array}{l}1988 \\
13 / \text { jul }\end{array}$ & $\begin{array}{l}\text { Jornal } \\
\text { Folha de } \\
\text { S.Paulo XLIII }\end{array}$ & $\begin{array}{l}\text { Acusação: O pe- } \\
\text { tróleo é o maior } \\
\text { poluidor do mun } \\
\text { do. Provas: }\end{array}$ & $\begin{array}{l}\text { Elenca uma série de malefícios do } \\
\text { petróleo como combustível e traz } \\
\text { depoimento de Böhm contrário ao } \\
\text { estímulo da volta do carro a gasolina. }\end{array}$ \\
\hline
\end{tabular}

XLI Órgão Informativo do Serviço de Assessoria às Comunidades do Interior

XLII Caderno Ciência e Tecnologia 


\begin{tabular}{|c|c|c|c|}
\hline DATA & $\mathrm{VC}^{*}$ & TÍTULO & ASSUNTO \\
\hline $\begin{array}{l}1988 \\
14 / \text { jul }\end{array}$ & $\begin{array}{l}\text { Jornal da } \\
\text { Tarde }\end{array}$ & $\begin{array}{l}\text { Londres, 1952: } \\
\text { poluição mortal }\end{array}$ & $\begin{array}{l}\text { Destaque de uma matéria maior que trata } \\
\text { do sucesso da Operação Alerta } 2 \text {, } \\
\text { ocorrida na véspera. Traz no destaque } \\
\text { depoimento de Böhm alertando para a } \\
\text { possibilidade de fato similar em S.Paulo } \\
\text { ao que se refere o título. }\end{array}$ \\
\hline $\begin{array}{l}1988 \\
16 / \text { jul }\end{array}$ & $\begin{array}{l}\text { Jornal O } \\
\text { Estado de } \\
\text { S.Paulo }\end{array}$ & $\begin{array}{l}\text { Álcool entra na } \\
\text { briga da poluição }\end{array}$ & 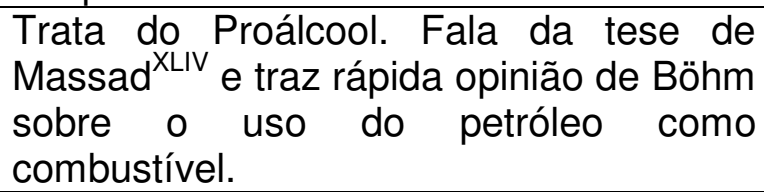 \\
\hline $\begin{array}{l}1988 \\
16 / \text { jul. }\end{array}$ & $\begin{array}{l}\text { Jornal O } \\
\text { Estado de } \\
\text { S.Paulo }\end{array}$ & $\begin{array}{l}\text { Os ratos ajudam } \\
\text { a entender os } \\
\text { homens }\end{array}$ & $\begin{array}{l}\text { Trata de pesquisas da FVUSP }{ }^{X L V} \text { e do } \\
\text { LPAE que se utilizam de ratos para } \\
\text { comparação dos poluentes do álcool e } \\
\text { gasolina. }\end{array}$ \\
\hline ausente & ausente & $\begin{array}{l}\text { Poluição de São } \\
\text { Paulo: ensaio } \\
\text { para emergência }\end{array}$ & $\begin{array}{l}\text { Artigo de autoria de Böhm trata da } \\
\text { simulação de impedimento de circulação } \\
\text { de veículos em determinados dias na } \\
\text { cidade. }\end{array}$ \\
\hline $\begin{array}{l}1988 \\
17 / \text { jul }\end{array}$ & $\begin{array}{l}\text { Jornal } \\
\text { Shopping } \\
\text { News - } \\
\text { City News }\end{array}$ & $\begin{array}{l}\text { O alerta que deu } \\
\text { certo }\end{array}$ & $\begin{array}{l}\text { Trata da Operação Alerta 2. Traz parecer } \\
\text { de Böhm sobre poluição atmosférica e } \\
\text { malefícios à saúde. }\end{array}$ \\
\hline $\begin{array}{l}1988 \\
27 / \text { jul }\end{array}$ & $\begin{array}{l}\text { Jornal } \\
\text { Folha de } \\
\text { S.Paulo }\end{array}$ & $\begin{array}{l}\text { Gasolina usada } \\
\text { no país tem alto } \\
\text { teor de chumbo }\end{array}$ & $\begin{array}{l}\text { Trata do assunto do título dando o } \\
\text { parecer de Böhm. }\end{array}$ \\
\hline $\begin{array}{l}1988 \\
2 / \text { set }\end{array}$ & $\begin{array}{l}\text { Jornal da } \\
\text { Tarde XLVI }\end{array}$ & $\begin{array}{l}\text { Verdade: } \\
\text { respirar faz mal }\end{array}$ & $\begin{array}{l}\text { Trata dos problemas à saúde causados } \\
\text { pela poluição atmosférica; }\end{array}$ \\
\hline $\begin{array}{l}1988 \\
10 \text { a } 12 \\
\text { set }\end{array}$ & $\begin{array}{l}\text { Revista } \\
\text { Indústria } \\
\text { Comércio } \\
\text { XLVII }\end{array}$ & $\begin{array}{l}\text { Professor aponta } \\
\text { meios de } \\
\text { preservação }\end{array}$ & $\begin{array}{l}\text { A partir de depoimento de Saldiva trata } \\
\text { das sugestões dadas por ele para } \\
\text { melhoria da qualidade do ar; são citadas } \\
\text { pesquisas do LPAE. }\end{array}$ \\
\hline 1989 & $\begin{array}{l}\text { Revista } \\
\text { Saúde é } \\
\text { Vital }^{\text {XLVIII }}\end{array}$ & $\begin{array}{l}\text { Álcool X } \\
\text { Gasolina }\end{array}$ & $\begin{array}{l}\text { Trata da poluição atmosférica veicular, da } \\
\text { pesquisa do LPAE para comparar } \\
\text { poluentes do álcool e gasolina; traz } \\
\text { depoimento de Böhm. }\end{array}$ \\
\hline $\begin{array}{l}1989 \\
07 / \text { set }\end{array}$ & $\begin{array}{l}\text { Jornal } \\
\text { Folha de } \\
\text { S.Paulo }\end{array}$ & $\begin{array}{l}\text { Poluição } \\
\text { atmosférica }\end{array}$ & $\begin{array}{l}\text { Artigo de autoria de Böhm trata do } \\
\text { aumento do teor de álcool na gasolina. }\end{array}$ \\
\hline $\begin{array}{l}1989 \\
21 / \text { out }\end{array}$ & $\begin{array}{l}\text { Jornal } \\
\text { Folha de } \\
\text { S.Paulo }\end{array}$ & $\begin{array}{l}\text { Pesquisa vai } \\
\text { avaliar relação } \\
\text { entre o fumo e } \\
\text { câncer }\end{array}$ & $\begin{array}{l}\text { Trata da pesquisa do título realizada pelo } \\
\text { LPAE em parceria com laboratório } \\
\text { canadense. }\end{array}$ \\
\hline
\end{tabular}

XLIII Provavelmente matéria paga pelo Proálcool - Governo Federal

xLIV Estudo Comparativo da Toxicidade dos Gases de exaustão de Motores Movidos a Álcool e Gasolina. 1984

${ }^{\mathrm{XLV}}$ Faculdade de Veterinária da Universidade de São Paulo

XLVI Caderno Cidade

XLVII Revista de circulação em Curitiba/PR.

XLVIII Ano $6 \mathrm{n}^{\circ} .9$ 


\begin{tabular}{|c|c|c|c|}
\hline DATA & VC* & TÍTULO & ASSUNTO \\
\hline $\begin{array}{l}1989 \\
20 / \text { nov }\end{array}$ & $\begin{array}{l}\text { Jornal } \\
\text { Folha de } \\
\text { S.Paulo }\end{array}$ & $\begin{array}{l}\text { Recursos } \\
\text { externos e meio } \\
\text { ambiente. }\end{array}$ & $\begin{array}{l}\text { Artigo de autoria de Böhm trata do tema } \\
\text { do título com críticas aos países } \\
\text { desenvolvidos. }\end{array}$ \\
\hline ausente & Ausente & $\begin{array}{l}\text { Poluição e doen- } \\
\text { ça, relação com- } \\
\text { provada pela } \\
\text { ciência }\end{array}$ & $\begin{array}{l}\text { Entrevista com Pereira sobre o assunto } \\
\text { do título; discorre sobre as pesquisas do } \\
\text { LPAE e sugere soluções. }\end{array}$ \\
\hline $\begin{array}{l}1990 \\
22 \text { a } 28 \\
\text { jan }\end{array}$ & $\begin{array}{l}\text { Jornal da } \\
\text { USP }\end{array}$ & $\begin{array}{l}\text { Documento da } \\
\text { USP examina } \\
\text { todos os riscos } \\
\text { do metanol }\end{array}$ & $\begin{array}{l}\text { Trata de documento sobre metanol } \\
\text { preparado pela FMUSP, Inst. de } \\
\text { Eletrotécnica e Energia (USP) e Assoc.de } \\
\text { Engenharia Automotiva e enviado ao } \\
\text { Ministério das Minas Energia. Cita e traz } \\
\text { foto de Saldiva. }\end{array}$ \\
\hline $\begin{array}{l}1990 \\
05 \text { a } 11 \\
\text { fev }\end{array}$ & $\begin{array}{l}\text { Boletim } \\
\text { Hospital } \\
\text { das } \\
\text { Clínicas XLIX }\end{array}$ & $\begin{array}{l}\text { A triste história } \\
\text { do metanol }\end{array}$ & $\begin{array}{l}\text { Artigo de Böhm trata de sua participação } \\
\text { em reunião junto ao Governo Federal } \\
\text { para a decisão de importação do } \\
\text { metanol. Relata sua indignação pela } \\
\text { decisão (da não importação) e denuncia } \\
\text { a irresponsabilidade dos governantes }\end{array}$ \\
\hline $\begin{array}{l}1992 \\
22 / \text { mar }\end{array}$ & $\begin{array}{l}\text { Jornal O } \\
\text { Estado de } \\
\text { S.Paulo }\end{array}$ & $\begin{array}{l}\text { Outono traz de } \\
\text { volta fantasma } \\
\text { da poluição }\end{array}$ & $\begin{array}{l}\text { Trata do agravamento da poluição } \\
\text { atmosférica no outono e proibição de } \\
\text { circulação de carros no Centro da cidade. } \\
\text { Traz depoimento de Saldiva com } \\
\text { sugestão de rodízio de carro permanente. }\end{array}$ \\
\hline $\begin{array}{l}1992 \\
05 / \text { out }\end{array}$ & $\begin{array}{l}\text { Jornal O } \\
\text { Estado de } \\
\text { S.Paulo }\end{array}$ & $\begin{array}{l}\text { Poluição de } \\
\text { carros mata } \\
\text { crianças }\end{array}$ & $\begin{array}{l}\text { A partir de depoimento de Saldiva trata, } \\
\text { de forma sucinta, da pesquisa do LPAE } \\
\text { sobre o assunto do título. }\end{array}$ \\
\hline $\begin{array}{l}1992 \\
05 / \text { out }\end{array}$ & $\begin{array}{l}\text { Jornal O } \\
\text { Estado de } \\
\text { S.Paulo }\end{array}$ & $\begin{array}{l}\text { Estudo liga polui } \\
\text { cão à mortalida- } \\
\text { de infantil }\end{array}$ & $\begin{array}{l}\text { A partir de depoimento de Saldiva } \\
\text { discorre longamente sobre a pesquisa do } \\
\text { LPAE sobre o assunto do título. }\end{array}$ \\
\hline $\begin{array}{l}1993 \\
17 / \text { mai }\end{array}$ & $\begin{array}{l}\text { Jornal O } \\
\text { Globo LII }\end{array}$ & $\begin{array}{l}\text { Estudo com } \\
\text { ratos prova que } \\
\text { o ar poluído } \\
\text { aumenta risco } \\
\text { de câncer }\end{array}$ & $\begin{array}{l}\text { Trata da pesquisa do título, realizado pelo } \\
\text { LPAE. Traz depoimento de Saldiva. Em } \\
\text { destaque, Saldiva discorre sobre o } \\
\text { assunto. }\end{array}$ \\
\hline $\begin{array}{l}1993 \\
23 / \text { jun }\end{array}$ & $\begin{array}{l}\text { Jornal } \\
\text { Folha de } \\
\text { S.Paulo }\end{array}$ & $\begin{array}{l}\text { Poluição do ar } \\
\text { em S.Paulo } \\
\text { piora }\end{array}$ & $\begin{array}{l}\text { Trata do assunto do título e traz } \\
\text { depoimento de Böhm. }\end{array}$ \\
\hline ausente & $\begin{array}{l}\text { Jornal } \\
\text { Folha de } \\
\text { S.Paulo }\end{array}$ & $\begin{array}{l}\text { Poluição mata } \\
\text { mais crianças } \\
\text { que AIDS }\end{array}$ & $\begin{array}{l}\text { Trata da pesquisa realizada pelo LPAE } \\
\text { da comparação citada no título. LIII }\end{array}$ \\
\hline
\end{tabular}

XLIX No. 7751

${ }^{\mathrm{L}}$ Caderno Geral

${ }^{\text {LI }}$ Caderno Pesquisa.

LII Caderno Ciência e Vida.

LIII Esta matéria gerou uma solicitação de envio de cópia da publicação da pesquisa na revista

Environmental Research por parte do Ministério Público. 


\begin{tabular}{|c|c|c|c|}
\hline DATA & $V^{*} *$ & TÍTULO & ASSUNTO \\
\hline $\begin{array}{l}1995 \\
04 / j u l\end{array}$ & $\begin{array}{l}\text { Jornal } \\
\text { Folha de } \\
\text { S.Paulo }\end{array}$ & $\begin{array}{l}\text { Males respira- } \\
\text { tórios infantis } \\
\text { aumentam com } \\
\text { poluição }\end{array}$ & $\begin{array}{l}\text { A partir do depoimento de Saldiva, } \\
\text { aborda a pesquisa do LPAE que } \\
\text { correlaciona internações hospitalares de } \\
\text { crianças com poluição atmosférica. }\end{array}$ \\
\hline $\begin{array}{l}1996 \\
\text { jan }\end{array}$ & Autodata $^{\text {LIV }}$ & Saúde & $\begin{array}{l}\text { Artigo de autoria de Böhm. Propõe a cria- } \\
\text { Cão de uma instituição patrocinada pela } \\
\text { indústria de transporte que visaria promo } \\
\text { ver o meio ambiente e estudar os efeitos } \\
\text { da poluição atmosférica sobre a saúde }\end{array}$ \\
\hline $\begin{array}{l}1996 \\
27 / \text { mai } \\
\text { a } \\
02 / \text { jun }\end{array}$ & $\begin{array}{l}\text { Jornal da } \\
\text { USP }\end{array}$ & $\begin{array}{l}\text { Os projetos para } \\
\text { deter os vilões } \\
\text { do ar }\end{array}$ & $\begin{array}{l}\text { Traz sugestões a partir de pesquisas } \\
\text { realizadas sobre poluição atmosférica. } \\
\text { Depoimento de Böhm sobre as } \\
\text { conseqüências à saúde. }\end{array}$ \\
\hline $\begin{array}{l}1996 \\
\text { out. }\end{array}$ & $\begin{array}{l}\text { Revista do } \\
\text { Incor }^{\mathrm{LV}}\end{array}$ & $\begin{array}{l}\text { A saúde sofre } \\
\text { com a poluição }\end{array}$ & $\begin{array}{l}\text { Entrevista com Böhm. Este traça um per- } \\
\text { fil do LPAE - histórico, perfil, pesquisas - } \\
\text { dos principais problemas de poluição } \\
\text { atuais e conseqüências para a saúde. }\end{array}$ \\
\hline $\begin{array}{l}1997 \\
\text { jun }\end{array}$ & $\begin{array}{l}\text { Revista } \\
\text { FAPESPLVI }\end{array}$ & $\begin{array}{l}\text { A poluição causa } \\
\text { doenças e mata }\end{array}$ & $\begin{array}{l}\text { Pesquisa referente à correlação entre } \\
\text { poluição atmosférica e risco de morte. }\end{array}$ \\
\hline $\begin{array}{l}1997 \\
\text { out }\end{array}$ & $\begin{array}{l}\text { Jornal da } \\
\text { Paulista }\end{array}$ & $\begin{array}{l}\text { Poluição e morte } \\
\text { em S.Paulo }\end{array}$ & $\begin{array}{l}\text { Trata da pesquisa realizada pelo LPAE } \\
\text { da cor relação entre poluição atmosférica } \\
\text { e risco de morte. Depoimento com } \\
\text { Débora Lobo.e gráfico dos resultados }\end{array}$ \\
\hline $\begin{array}{l}1997 \\
04 \text { a } 10 \\
\text { out }\end{array}$ & $\begin{array}{l}\text { Jornal da } \\
\text { USP }\end{array}$ & $\begin{array}{l}\text { Em cidade } \\
\text { poluída vive-se } \\
\text { menos }\end{array}$ & $\begin{array}{l}\text { Trata da pesquisa realizada pelo LPAE } \\
\text { da correlação entre poluição atmosférica } \\
\text { e risco de morte. Traz depoimento de } \\
\text { Saldiva (c/foto) e gráfico dos resultados }\end{array}$ \\
\hline $\begin{array}{l}1998 \\
\text { mai }\end{array}$ & $\begin{array}{l}\text { Jornal da } \\
\text { Tarde }\end{array}$ & $\begin{array}{l}\text { O que o inverno } \\
\text { faz com a gente }\end{array}$ & $\begin{array}{l}\text { Trata das conseqüências para a saúde } \\
\text { da estação do título; traz depoimento de } \\
\text { Saldiva. }\end{array}$ \\
\hline $\begin{array}{l}1998 \\
03 / \text { mai }\end{array}$ & $\begin{array}{l}\text { Jornal O } \\
\text { Estado de } \\
\text { S.Paulo }\end{array}$ & $\begin{array}{l}\text { Pesquisa da } \\
\text { USP relaciona } \\
\text { mortes e } \\
\text { poluição }\end{array}$ & $\begin{array}{l}\text { Refere-se à Saldiva já no subtítulo e fala } \\
\text { da pesquisa do LPAE referida no título. }\end{array}$ \\
\hline $\begin{array}{l}1998 \\
29 / \text { mai }\end{array}$ & $\begin{array}{l}\text { Jornal } \\
\text { Tribuna } \\
\text { Imprensa } \\
\text { LVIII }\end{array}$ & $\begin{array}{l}\text { Jornada vai } \\
\text { discutir efeitos } \\
\text { da fumaça }\end{array}$ & $\begin{array}{l}\text { Trata da V Jornada de Pneumologia de } \\
\text { Araraquara com depoimento de Arbex } \\
\text { sobre estudos com queimadas de cana- } \\
\text { de-açúcar; cita Saldiva na abertura. }\end{array}$ \\
\hline $\begin{array}{l}1998 \\
21 / \text { mai }\end{array}$ & $\begin{array}{l}\text { AUN- } \\
\text { Agência } \\
\text { Universitá- } \\
\text { ria de } \\
\text { Notícias }\end{array}$ & $\begin{array}{l}\text { Poluição pode } \\
\text { provocar altera- } \\
\text { ções em células } \\
\text { de plantas e } \\
\text { animais }\end{array}$ & $\begin{array}{l}\text { A partir do depoimento de Pereira trata } \\
\text { dos estudos do LPAE utilizando-se de } \\
\text { plantas e animais }\end{array}$ \\
\hline
\end{tabular}

\footnotetext{
LIV Informativo mensal sobre tecnologia automotiva integrante de autodata $-n^{\circ} .66$

LV Ano $2-\mathrm{n}^{\circ} .19$

${ }^{\text {LVI }}$ Publicação mensal da Fundação de Amparo à Pesquisa do Estado de São Paulo

${ }^{\text {LVII }}$ UNIFESP/Escola Paulista de Medicina - ano $11-\mathrm{n}^{\circ} .112$.

LVIII Circula na região de Araraquara/SP.

${ }^{\text {LIX }}$ Jornal da Escola de Comunicações e Artes da USP - ano 31 nº. 7
} 


\begin{tabular}{|c|c|c|c|}
\hline DATA & $\mathrm{VC}^{*}$ & TÍTULO & ASSUNTO \\
\hline $\begin{array}{l}1998 \\
30 / \text { mai }\end{array}$ & $\begin{array}{l}\text { Jornal O } \\
\text { Imparcial }^{\text {LX }}\end{array}$ & $\begin{array}{l}\text { Terminam hoje } \\
\text { os debates } \\
\text { sobre doenças } \\
\text { respiratórias }\end{array}$ & $\begin{array}{l}\text { Trata da V Jornada de Pneumologia de } \\
\text { Araraquara, destacando a palestra de } \\
\text { abertura de Saldiva. }\end{array}$ \\
\hline $\begin{array}{l}1998 \\
31 / \text { mai }\end{array}$ & $\begin{array}{l}\text { Jornal O } \\
\text { Imparcial }\end{array}$ & $\begin{array}{l}\text { Doenças respira- } \\
\text { tórias são as } \\
\text { campeãs de } \\
\text { internações e } \\
\text { custos } \\
\text { hospitalares }\end{array}$ & $\begin{array}{l}\text { Trata da V Jornada de Pneumologia, traz } \\
\text { depoimento e foto em destaque de } \\
\text { Saldiva falando sobre o tema do título. }\end{array}$ \\
\hline $\begin{array}{l}1998 \\
20 / \text { ago }\end{array}$ & $\begin{array}{l}\text { Jornal O } \\
\text { Estado de } \\
\text { S.Paulo }\end{array}$ & $\begin{array}{l}\text { Sistema analisa- } \\
\text { rá doenças cau- } \\
\text { sadas por } \\
\text { poluição }\end{array}$ & $\begin{array}{l}\text { Trata da possibilidade de criação de um } \\
\text { sistema de vigilância epidemiológica em } \\
\text { poluição ambiental. Cita pesquisas do } \\
\text { LPAE e Saldiva. }\end{array}$ \\
\hline $\begin{array}{l}1998 \\
01 / \text { set }\end{array}$ & $\begin{array}{l}\text { Jornal O } \\
\text { Estado de } \\
\text { S.Paulo }\end{array}$ & $\begin{array}{l}\text { Poluição do ar } \\
\text { pode prejudicar } \\
\text { pulmão mais do } \\
\text { que o cigarro }\end{array}$ & $\begin{array}{l}\text { A partir do depoimento de Souza trata do } \\
\text { estudo do título realizado no LPAE e tese } \\
\text { da tese de doutorado do entrevistado. }\end{array}$ \\
\hline $\begin{array}{l}1998 \\
02 / \text { set }\end{array}$ & $\begin{array}{l}\text { Jornal O } \\
\text { Estado de } \\
\text { S.Paulo }\end{array}$ & $\begin{array}{l}\text { Médicos } \\
\text { desaconselham } \\
\text { exercício em dia } \\
\text { poluído }\end{array}$ & $\begin{array}{l}\text { Como destaque de uma matéria maior, } \\
\text { traz o depoimento de Saldiva sobre o } \\
\text { tema do título. }\end{array}$ \\
\hline $\begin{array}{l}1999 \\
\text { jan/fev }\end{array}$ & ausente & $\begin{array}{l}\text { Ciência e } \\
\text { Política }\end{array}$ & $\begin{array}{l}\text { De autoria de Böhm trata da política } \\
\text { científica no Brasil. }\end{array}$ \\
\hline $\begin{array}{l}1999 \\
17 \text { a } 23 \\
\text { dez }\end{array}$ & $\begin{array}{l}\text { Jornal do } \\
\text { Trem }\end{array}$ & $\begin{array}{l}\text { Poluentes em } \\
\text { mananciais pau- } \\
\text { listas causam } \\
\text { mutações gene- } \\
\text { ticas em plantas }\end{array}$ & $\begin{array}{l}\text { A partir de depoimento de Ana Júlia } \\
\text { Lichtenfels trata de pesquisa do LPAE } \\
\text { referido no título. }\end{array}$ \\
\hline $\begin{array}{l}2000 \\
\text { mar }\end{array}$ & $\begin{array}{l}\text { Noticiário } \\
\text { Departa } \\
\text { mento de } \\
\text { Patologia } \\
\text { LXI }\end{array}$ & $\begin{array}{l}\text { Notas sobre a } \\
\text { história do depar } \\
\text { tamento de Pato } \\
\text { logia da FMUSP }\end{array}$ & $\begin{array}{l}\text { Aborda o histórico do departamento e } \\
\text { prolonga-se no histórico do LPAE, com } \\
\text { fotos de vários pesquisadores. }\end{array}$ \\
\hline $\begin{array}{l}2001 \\
\text { jun }\end{array}$ & $\begin{array}{l}\text { Jornal } \\
\text { Folha de } \\
\text { S.Paulo }\end{array}$ & $\begin{array}{l}\text { Incinerador } \\
\text { Vergueiro } \\
\text { começa a ser } \\
\text { fechado }\end{array}$ & 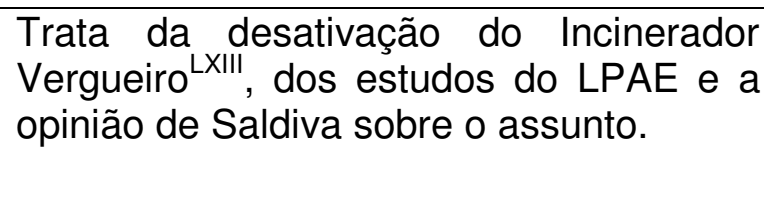 \\
\hline $\begin{array}{l}2001 \\
\text { nov }\end{array}$ & ausente & $\begin{array}{l}\mathrm{O} \text { ar que você } \\
\text { respira }\end{array}$ & $\begin{array}{l}\text { De autoria de Débora Lobo aborda as } \\
\text { pesquisas do LPAE em relação ao tema } \\
\text { do título. }\end{array}$ \\
\hline
\end{tabular}

${ }^{\text {LX }}$ Circula na região de Araraquara/SP.

LXI Periódico da FMUSP n ${ }^{\circ} .1$ ano 1.

LXII Caderno Cotidiano

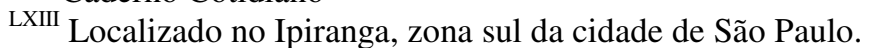




\begin{tabular}{|c|c|c|c|}
\hline DATA & $V^{*} *$ & TÍTULO & ASSUNTO \\
\hline ausente & ausente ${ }^{\text {LXIV }}$ & $\begin{array}{l}\text { Plantas } \\
\text { detectam a } \\
\text { presença de } \\
\text { poluentes no } \\
\text { município }\end{array}$ & $\begin{array}{l}\text { Tem como subtítulo "Projeto de Paulo } \\
\text { Saldiva foi apresentado a vereadores e } \\
\text { estudantes". Trata da apresentação em } \\
\text { Cubatão/SP de proposta de projeto para } \\
\text { avaliação de poluentes realizada por } \\
\text { estudantes de Ensino Básico. }\end{array}$ \\
\hline $\begin{array}{l}2002 \\
\text { jun }\end{array}$ & $\begin{array}{l}\text { Revista } \\
\text { Super } \\
\text { Interessant } \\
\mathrm{e}^{\mathrm{LXV}}\end{array}$ & $\begin{array}{l}\text { O alerta das } \\
\text { plantas }\end{array}$ & $\begin{array}{l}\text { Discorre o projeto condecorado com o } \\
\text { Prêmio Super Ecologia, em parceria com } \\
\text { o Instituto de Botânica, para biomonitora- } \\
\text { mento do ar com a utilização da planta do } \\
\text { tabaco }\end{array}$ \\
\hline $\begin{array}{l}2002 \\
a b r\end{array}$ & $\begin{array}{l}\text { Jornal do } \\
\text { CREMESP }\end{array}$ & $\begin{array}{l}\text { Poluição } \\
\text { aumenta a } \\
\text { mortalidade } \\
\text { infantil }\end{array}$ & $\begin{array}{l}\text { Entrevista (com foto) com Luiz A. Pereira } \\
\text { trata do assunto do título, discorrendo } \\
\text { sobre as pesquisas do LPAE e propostas } \\
\text { de solução. }\end{array}$ \\
\hline $\begin{array}{l}2002 \\
12 / \text { mai }\end{array}$ & $\begin{array}{l}\text { Diário de } \\
\text { S.Paulo }\end{array}$ & $\begin{array}{l}\text { Ar melhora em } \\
\text { São Paulo mas a } \\
\text { poluição por } \\
\text { ozônio é nova } \\
\text { ameaça }\end{array}$ & $\begin{array}{l}\text { Trata do assunto do título com } \\
\text { depoimento de Luiz A. Pereira. }\end{array}$ \\
\hline \multirow[t]{2}{*}{$\begin{array}{l}2002 \\
13 / j u n\end{array}$} & \multirow{2}{*}{$\begin{array}{l}\text { Jornal } \\
\text { Setecidade } \\
\text { s - Diário } \\
\text { do Grande } \\
\text { ABC }\end{array}$} & $\begin{array}{l}\text { Plantas vão } \\
\text { medir poluição } \\
\text { do ar }\end{array}$ & $\begin{array}{l}\text { Aborda o lançamento de um programa de } \\
\text { biomonitoramento de poluição do ar em } \\
\text { parceria do LPAE com o SEMASA }{ }^{\mathrm{LXVI}} \text {. } \\
\text { Traz depoimento e foto de Saldiva. }\end{array}$ \\
\hline & & $\begin{array}{l}\text { Saúde discute } \\
\text { caso semana } \\
\text { que vem }\end{array}$ & $\begin{array}{l}\text { Trata de suposta epidemia de tireoidite } \\
\text { de Hashimoto, detectada em bairros } \\
\text { próximos ao pólo petroquímico de } \\
\text { Capuava/SP. Saldiva dá depoimento. }\end{array}$ \\
\hline $\begin{array}{l}2002 \\
18 / \text { jun }\end{array}$ & $\begin{array}{l}\text { Jornal O } \\
\text { Estado de } \\
\text { S.Paulo }\end{array}$ & $\begin{array}{l}\text { FMUSP inaugu- } \\
\text { ra seu programa } \\
\text { de telemedicina }\end{array}$ & $\begin{array}{l}\text { Trata do assunto do título, citando Böhm } \\
\text { e Saldiva. }\end{array}$ \\
\hline \multirow[t]{2}{*}{$\begin{array}{l}2002 \\
12 \text { a } 18 \\
\text { ago }\end{array}$} & \multirow[t]{2}{*}{$\begin{array}{l}\text { Jornal da } \\
\text { USP }\end{array}$} & $\begin{array}{l}\text { Aulas de } \\
\text { autópsia pela } \\
\text { internet }\end{array}$ & $\begin{array}{l}\text { A partir de depoimento de Saldiva, } \\
\text { aborda o Programa de Telemedicina do } \\
\text { Departamento de Patologia. }\end{array}$ \\
\hline & & $\begin{array}{l}\text { O ensino da } \\
\text { patologia no } \\
\text { currículo medico }\end{array}$ & $\begin{array}{l}\text { De autoria de Saldiva, discorre sobre o } \\
\text { assunto do tema. }\end{array}$ \\
\hline $\begin{array}{l}2002 \\
16 / \text { ago }\end{array}$ & $\begin{array}{l}\text { Jornal } \\
\text { Setecidade } \\
\text { s - Diário } \\
\text { do Grande } \\
\text { ABC }\end{array}$ & $\begin{array}{l}\text { Um ano depois, } \\
\text { faltam respostas }\end{array}$ & $\begin{array}{l}\text { Aborda a situação dos moradores dos } \\
\text { edifícios construídos sobre solo } \\
\text { contaminado por lixo industrial enterrados } \\
\text { no subsolo. Saldiva é citado como pesqui } \\
\text { sador que tenta identificar alterações na } \\
\text { água do condomínio. }\end{array}$ \\
\hline
\end{tabular}

LXIV Provavelmente trata-se do jornal “A Tribuna” que circula na Baixada Santista.

LXV Edição 177

${ }^{\text {LXVI }}$ Serviço Municipal de Saneamento Ambiental de Santo André. 


\begin{tabular}{|c|c|c|c|}
\hline DATA & $\mathrm{VC}^{*}$ & TÍTULO & ASSUNTO \\
\hline \multirow[t]{3}{*}{$\begin{array}{l}2002 \\
02 \text { a } 08 \\
\text { dez }\end{array}$} & \multirow[t]{3}{*}{$\begin{array}{l}\text { Jornal da } \\
\text { USP }\end{array}$} & $\begin{array}{l}\text { Poluição atinge } \\
\text { mais população } \\
\text { carente }\end{array}$ & $\begin{array}{l}\text { Trata de estudo realizado pelo LPAE } \\
\text { sobre o tema do título }\end{array}$ \\
\hline & & $\begin{array}{l}\text { Os agressivos } \\
\text { ares da } \\
\text { metrópole }\end{array}$ & $\begin{array}{l}\text { Trata da correlação da poluição atmosféri } \\
\text { ca com a saúde; traz depoimentos de } \\
\text { Alfésio Braga, Eliane Tigre e Chin An Lin. }\end{array}$ \\
\hline & & $\begin{array}{l}\text { Efeitos mais } \\
\text { dramáticos em } \\
\text { população } \\
\text { carente }\end{array}$ & $\begin{array}{l}\text { Discorre sobre estudo de Maria C.H. Mar- } \\
\text { tins: distribuição espacial das doenças } \\
\text { associadas à poluição atmosférica. }\end{array}$ \\
\hline $\begin{array}{l}2002 \\
16 / \mathrm{dez}\end{array}$ & $\begin{array}{l}\text { Jornal O } \\
\text { Estado de } \\
\text { S.Paulo }\end{array}$ & $\begin{array}{l}\text { Ar condicionado: } \\
\text { vilão escondido } \\
\text { nos escritórios }\end{array}$ & $\begin{array}{l}\text { Aborda estudo realizado pela FMUSP } \\
\text { referente ao título e traz comentário de } \\
\text { Saldiva. }\end{array}$ \\
\hline $\begin{array}{l}2003 \\
07 / \mathrm{fev}\end{array}$ & $\begin{array}{l}\text { Site Diário } \\
\text { de S.Pau- } \\
\text { lo On- } \\
\text { line } \text { LXVII }^{-}\end{array}$ & $\begin{array}{l}\text { Risco de contrair } \\
\text { doenças } \\
\text { aumenta }\end{array}$ & $\begin{array}{l}\text { Depoimento de Alfésio Braga, } \\
\text { considerando um retrocesso a redução } \\
\text { do teor de álcool na gasolina e avaliando } \\
\text { as conseqüências para a saúde. }\end{array}$ \\
\hline $\begin{array}{l}2003 \\
07 / \mathrm{fev}\end{array}$ & $\begin{array}{l}\text { Site Folha } \\
\text { On } \\
\text { Line }\end{array}$ & $\begin{array}{l}\text { Mudança na } \\
\text { gasolina } \\
\text { aumenta } \\
\text { poluição }\end{array}$ & $\begin{array}{l}\text { Trata do aumento do teor de álcool na } \\
\text { gasolina e as conseqüências ambientais. } \\
\text { Cita o LPAE e traz parecer de Saldiva. }\end{array}$ \\
\hline $\begin{array}{l}2003 \\
07 / \text { set }\end{array}$ & $\begin{array}{l}\text { Jornal } \\
\text { Diário de } \\
\text { S.Paulo }\end{array}$ & $\begin{array}{l}\text { A poluição } \\
\text { diminui em até } \\
\text { três anos a vida } \\
\text { do paulistano }\end{array}$ & $\begin{array}{l}\text { Entrevista (com foto) com Saldiva. Trata } \\
\text { do assunto do título, discorrendo sobre as } \\
\text { pesquisas do LPAE e discute sobre } \\
\text { questões afins como o rodízio de carro. } \\
\text { Em destaque traz perfil de Saldiva. }\end{array}$ \\
\hline $\begin{array}{l}2003 \\
19 / \text { set }\end{array}$ & $\begin{array}{l}\text { Site Folha } \\
\text { Online }\end{array}$ & $\begin{array}{l}\text { Experiência re- } \\
\text { produz efeito de } \\
\text { poluentes sobre } \\
\text { a raça humana }\end{array}$ & $\begin{array}{l}\text { A partir de depoimento de Saldiva trata } \\
\text { da pesquisa do LPAE sobre os efeitos à } \\
\text { saúde por exposição prolongada } \\
\text { utilizando ratos em câmaras filtradas. }\end{array}$ \\
\hline $\begin{array}{l}2004 \\
\text { abril }\end{array}$ & $\begin{array}{l}\text { Médico } \\
\text { repórter }{ }^{\text {LXIX }}\end{array}$ & $\begin{array}{l}\text { Utilização de } \\
\text { Tradescantia } \\
\text { pallida no bio- } \\
\text { monitoramento } \\
\text { ambiental }\end{array}$ & $\begin{array}{l}\text { Artigo escrito por Débora Lobo traz } \\
\text { histórico do LPAE e das pesquisas em } \\
\text { que são utilizadas plantas. }\end{array}$ \\
\hline $\begin{array}{l}2004 \\
25 / \text { mai }\end{array}$ & $\begin{array}{l}\text { Jornal } \\
\text { Folha } \\
\text { [sinapse] }^{1}\end{array}$ & $\begin{array}{l}\text { Por um respiro } \\
\text { mais leve }\end{array}$ & $\begin{array}{l}\text { Longa entrevista com Saldiva, com várias } \\
\text { fotos deste pedalando por S.Paulo. } \\
\text { Aborda a vida pessoal e profissional, o } \\
\text { LPAE e suas principais pesquisas. }\end{array}$ \\
\hline $\begin{array}{l}2004 \\
13 / \text { jul }\end{array}$ & ausente & $\begin{array}{l}\text { Eficiência } \\
\text { tecnológica } \\
\text { reduz emissões }\end{array}$ & $\begin{array}{l}\text { Aborda as conseqüências à saúde das } \\
\text { emissões dos automóveis; refere-se à } \\
\text { pesquisa de Simone Miraglia que estudou } \\
\text { a correlação entre poluição atmosférica e } \\
\text { mortalidade. }\end{array}$ \\
\hline
\end{tabular}

LXVII Disponível em http://www.diariosp.com.br/

LXVIII Disponível na página http://www1.folha.uol.com.br/fsp/

LXIX Periódico direcionado a médicos - ano $6 \mathrm{n}^{\circ} .54$ 


\begin{tabular}{|c|c|c|c|}
\hline DATA & $\mathrm{VC}^{*}$ & TÍTULO & ASSUNTO \\
\hline $\begin{array}{l}2004 \\
09 / \text { set }\end{array}$ & $\begin{array}{l}\text { Jornal O } \\
\text { Estado de } \\
\text { S.Paulo }\end{array}$ & $\begin{array}{l}\text { Ar muito seco } \\
\text { cobre S.Paulo. } \\
\text { No Sul, chuva }\end{array}$ & $\begin{array}{l}\text { Trata o assunto do título trazendo parecer } \\
\text { do pesquisador Ubiratan Paula Santos. }\end{array}$ \\
\hline $\begin{array}{l}2004 \\
\text { set/out }\end{array}$ & $\begin{array}{l}\text { Jornal da } \\
\text { FFM }^{\mathrm{LXX}}\end{array}$ & $\begin{array}{l}\text { Por uma vida } \\
\text { (muito) mais } \\
\text { saudável }\end{array}$ & $\begin{array}{l}\text { Reportagem com Saldiva (traz foto) } \\
\text { discorre sobre sua vida pessoal e } \\
\text { profissional. }\end{array}$ \\
\hline $\begin{array}{l}2004 \\
18 / \text { out }\end{array}$ & $\begin{array}{l}\text { Jornal A } \\
\text { Tribuna }\end{array}$ & $\begin{array}{l}\text { O alerta do } \\
\text { coração roxo }\end{array}$ & $\begin{array}{l}\text { Discorre sobre dois estudos que estão } \\
\text { sendo realizados pelo LPAE com } \\
\text { Tradescantia em Cubatão, realizado por } \\
\text { alunos de Ensino Básico e outro em } \\
\text { Santo André. Cita Nilva Campina, Mônica } \\
\text { Lobarinhas e Eriane Justo. }\end{array}$ \\
\hline $\begin{array}{l}2004 \\
02 / \text { nov }\end{array}$ & $\begin{array}{l}\text { Correio do } \\
\text { Estado LXXII }\end{array}$ & $\begin{array}{l}\text { Crimes sem } \\
\text { culpa, castigo ou } \\
\text { culpados }\end{array}$ & $\begin{array}{l}\text { Trata de palestra dada por Saldiva. Foca } \\
\text { a fala de Saldiva na questão da falta de } \\
\text { legislação, no Brasil, que regulamente a } \\
\text { emissão de óxidos de nitrogênio. Cita o } \\
\text { LPAE como "um dos sete melhores } \\
\text { grupos do mundo na área de pesquisa } \\
\text { que investiga os efeitos da poluição sobre } \\
\text { a saúde humana". }\end{array}$ \\
\hline $\begin{array}{l}2004 \\
08 / \text { nov }\end{array}$ & $\begin{array}{l}\text { Site } \\
\text { Agência } \\
\text { USP de } \\
\text { Notícias } \\
\text { LXXIII }\end{array}$ & $\begin{array}{l}\text { Apesar da } \\
\text { adesão Russa, } \\
\text { protocolo de } \\
\text { Kyoto só decola } \\
\text { com os EUA }\end{array}$ & $\begin{array}{l}\text { Discorre sobre o protocolo de Kyoto, a } \\
\text { adesão ou não de alguns países e a } \\
\text { opinião de Böhm sobre o assunto. }\end{array}$ \\
\hline 2004 & $\begin{array}{l}\text { Revista } \\
\text { Essencial }\end{array}$ & $\begin{array}{l}\text { Estudando os } \\
\text { efeitos da } \\
\text { poluição }\end{array}$ & $\begin{array}{l}\text { Discorre sobre o LPAE desde seu início, } \\
\text { cita Böhm e Saldiva e algumas } \\
\text { pesquisas. }\end{array}$ \\
\hline $\begin{array}{l}2005 \\
07 / \text { mar }\end{array}$ & $\begin{array}{l}\text { Jornal O } \\
\text { Estado de } \\
\text { S.Paulo }\end{array}$ & $\begin{array}{l}\text { Ar poluído } \\
\text { prejudica o } \\
\text { coração }\end{array}$ & $\begin{array}{l}\text { Trata da pesquisa do LPAE realizada por } \\
\text { Dolores Rivero sobre a correlação entre } \\
\text { poluição e freqüência cardíaca. }\end{array}$ \\
\hline $\begin{array}{l}2005 \\
13 / \text { mar }\end{array}$ & $\begin{array}{l}\text { Jornal da } \\
\text { USP }\end{array}$ & $\begin{array}{l}\text { A ciência contra } \\
\text { os dramas da } \\
\text { cidade }\end{array}$ & $\begin{array}{l}\text { Matéria sobre Saldiva e suas pesquisas. } \\
\text { Discorre sobre pesquisadores que tem } \\
\text { seus estudos correlacionados com } \\
\text { grandes problemas da cidade. }\end{array}$ \\
\hline $\begin{array}{l}2005 \\
22 / \text { jun }\end{array}$ & $\begin{array}{l}\text { Jornal O } \\
\text { Estado de } \\
\text { S.Paulo }\end{array}$ & $\begin{array}{l}\text { Poluição do ar } \\
\text { reduz nascimen- } \\
\text { to de meninos }\end{array}$ & $\begin{array}{l}\text { Trata do assunto do título a partir de } \\
\text { entrevista com Saldiva e Ana Júlia } \\
\text { Lichtenfels, responsável pelo estudo em } \\
\text { questão. }\end{array}$ \\
\hline $\begin{array}{l}2005 \\
22 / j u n\end{array}$ & $\begin{array}{l}\text { Jornal } \\
\text { MetrôNew } \\
\text { s }\end{array}$ & $\begin{array}{l}\text { Poluição reduz } \\
\text { índices de nasci- } \\
\text { mento de } \\
\text { meninos }\end{array}$ & $\begin{array}{l}\text { Trata do assunto do título a partir de } \\
\text { entrevista com Saldiva e Joabner Gomes, } \\
\text { responsáveis por uma das vertentes do } \\
\text { estudo. }\end{array}$ \\
\hline
\end{tabular}

LXX Publicação bimestral da Fundação Faculdade de Medicina/USP

LXXI Jornal de circulação na Baixada Santista/SP.

LXXII Jornal de circulação em Campo Grande/MS

LXXIII Disponível em http://www.usp.br/agenciausp 


\begin{tabular}{l|l|l|l}
\hline \multicolumn{1}{c|}{ DATA } & \multicolumn{1}{|c|}{ VC* } & \multicolumn{1}{c}{ TíTULO } & \multicolumn{1}{c}{ ASSUNTO } \\
\hline 2005 & $\begin{array}{l}\text { Agência } \\
\text { USP de } \\
\text { notícias } \\
\text { LXXIV }\end{array}$ & $\begin{array}{l}\text { Pesquisa mostra } \\
\text { como a poluição } \\
\text { prejudica o siste- } \\
\text { ma cardiopulmo- } \\
\text { nar de ratos }\end{array}$ & $\begin{array}{l}\text { Aborda a pesquisa do LPAE sobre o } \\
\text { assunto do título, realizada por Dolores } \\
\text { Rivero. }\end{array}$ \\
\hline 2005 & $\begin{array}{l}\text { Revista } \\
\text { VejaLXXV }\end{array}$ & $\begin{array}{l}\text { Fumaça rima } \\
\text { com ameaça }\end{array}$ & $\begin{array}{l}\text { Matéria de quatro páginas sobre os } \\
\text { estudos científicos que correlacionam } \\
\text { poluição e saúde, sendo Saldiva um dos } \\
\text { entrevistados. }\end{array}$ \\
\hline 2005 & $\begin{array}{l}\text { Jornal } \\
\text { Folha de } \\
\text { S.Paulo } \\
\text { LXXVI }\end{array}$ & $\begin{array}{l}\text { Poluição } \\
\text { prejudica o } \\
\text { coração de } \\
\text { roedores }\end{array}$ & $\begin{array}{l}\text { Trata da pesquisa do LPAE sobre o } \\
\text { assunto do título, realizada por Dolores } \\
\text { Rivero. }\end{array}$ \\
\hline ausente & $\begin{array}{l}\text { Jornal da } \\
\text { FFM }\end{array}$ & $\begin{array}{l}\text { Dr. Paulo Saldi- } \\
\text { va batiza o 10 } \\
\text { Prêmio das Li- } \\
\text { gas Acadêmicas }\end{array}$ & $\begin{array}{l}\text { Trata do assunto do título com foto de } \\
\text { Saldiva. }\end{array}$ \\
\hline 2005 & $\begin{array}{l}\text { Site } \\
\text { Agência } \\
\text { FAPESP } \\
\text { LXXVII }\end{array}$ & $\begin{array}{l}\text { Em busca do ar } \\
\text { perdido }\end{array}$ & $\begin{array}{l}\text { Entrevista com Saldiva (c/foto) trata da } \\
\text { poluição atmosférica na cidade de } \\
\text { S.Paulo. }\end{array}$ \\
\hline ausente & $\begin{array}{l}\text { O Portal } \\
\text { de } \\
\text { Guarulhos } \\
\text { LXXVIII }\end{array}$ & $\begin{array}{l}\text { Trânsito } \\
\text { congestionado } \\
\text { no coração }\end{array}$ & $\begin{array}{l}\text { Trata da pesquisa do LPAE realizada por } \\
\text { Dolores Rivero sobre a correlação entre } \\
\text { poluição e freqüência cardíaca. }\end{array}$ \\
\hline
\end{tabular}

* VC - veículo de comunicação

OBS.: Para melhor visualização, optou-se por seguir ordem cronológica e não a ordem estabelecida no documento. Foram excluídas as reportagens que não citavam o LPAE, seus pesquisadores e/ou trabalho $\mathrm{S}$.

\footnotetext{
LXXIV Boletim n ${ }^{\circ} .1656$

LXXV Edição 1911 - ano 38 - n²6

LXXvi Caderno Ciência.

LXXVII Disponível em

http://www.agencia.fapesp.br/boletim_dentro.php?data[id_materia_boletim] $=447$

LXXVIII Não foi possível definir o veículo de comunicação.
} 


\section{Resumo dos artigo publicados na mídia não acadêmicas e arquivados}

pela secretaria do LPAE entre maio de 2005 a junho de 2007

\begin{tabular}{|c|c|c|c|}
\hline DATA & $\mathrm{VC}^{*}$ & TÍTULO & ASSUNTO \\
\hline \multirow[t]{2}{*}{$\begin{array}{l}2005 \\
05 / \text { mai }\end{array}$} & \multirow{2}{*}{$\begin{array}{l}\text { Jornal } \\
\text { Folha de } \\
\text { S.Paulo } \\
\text { LXXIX }\end{array}$} & $\begin{array}{l}\text { Medicamentos e } \\
\text { informação corre } \\
\text { ta ajudam quem } \\
\text { sofre com o frio }\end{array}$ & \multirow{2}{*}{$\begin{array}{l}\text { Trata do aumento de incidência de } \\
\text { doenças alérgicas associada à poluição. } \\
\text { Traz depoimento de Alfésio Braga. }\end{array}$} \\
\hline & & Virada de tempo & \\
\hline $\begin{array}{l}2005 \\
19 / j u l\end{array}$ & $\begin{array}{l}\text { Jornal } \\
\text { Folha de } \\
\text { S.Paulo }^{43}\end{array}$ & $\begin{array}{l}\text { Ar rarefeito: ôni- } \\
\text { bus de SP têm } \\
\text { poluição medida }\end{array}$ & $\begin{array}{l}\text { Aborda o assunto do título e se estende } \\
\text { às conseqüências deste tipo de poluição } \\
\text { à saúde com depoimento de Saldiva. }\end{array}$ \\
\hline \multirow[t]{2}{*}{$\begin{array}{l}2005 \\
18 / \text { ago }\end{array}$} & $\begin{array}{l}\text { Jornal } \\
\text { Folha de } \\
\text { S.Paulo }^{41}\end{array}$ & \multirow[t]{2}{*}{$\begin{array}{l}\text { Poluição em SP } \\
\text { mata oito por dia }\end{array}$} & \multirow{2}{*}{$\begin{array}{l}\text { A reportagem procura subsidiar o título } \\
\text { através de pesquisas do LPAE e informa- } \\
\text { ções concedidas por Saldiva que, na } \\
\text { verdade, fala de mortes induzidas por } \\
\text { problemas da poluição. }\end{array}$} \\
\hline & $\begin{array}{l}\text { Site Folha } \\
\text { On Line }\end{array}$ & & \\
\hline \begin{tabular}{l|}
2005 \\
$25 /$ ago
\end{tabular} & $\begin{array}{l}\text { Jornal O } \\
\text { Estado de } \\
\text { S.Paulo }\end{array}$ & $\begin{array}{l}\text { Novela } \\
\text { interminável }\end{array}$ & $\begin{array}{l}\text { Refere-se à busca do governo municipal } \\
\text { de S.Paulo por autorização do governo } \\
\text { federal para colocar em prática o progra- } \\
\text { ma de inspeção conjunta dos itens mecâ- } \\
\text { nicos e ambientais da frota paulistana. Ci- } \\
\text { ta estudos do LPAE. }\end{array}$ \\
\hline $\begin{array}{l}2005 \\
30 / \text { ago }\end{array}$ & $\begin{array}{l}\text { Jornal } \\
\text { Folha de } \\
\text { S.Paulo }\end{array}$ & $\begin{array}{l}\text { Caminho da } \\
\text { poluição: ciclo- } \\
\text { via na marginal } \\
\text { custará } R \$ 11,2 \\
\text { milhões }\end{array}$ & $\begin{array}{l}\text { Trata da instalação de ciclovia na cidade } \\
\text { de S.Paulo. Traz depoimento de Saldiva } \\
\text { que correlaciona a prática de exercícios } \\
\text { físicos e saúde. }\end{array}$ \\
\hline $\begin{array}{l}2005 \\
15 / \text { out }\end{array}$ & $\begin{array}{l}\text { Site } \\
\text { Agência } \\
\text { Repórter } \\
\text { Social }\end{array}$ & $\begin{array}{l}\text { Cientistas e } \\
\text { OMS apóiam o } \\
\text { uso da bicicleta } \\
\text { no cotidiano mês } \\
\text { mo nos grandes } \\
\text { centros poluídos }\end{array}$ & $\begin{array}{l}\text { Trata do assunto do título. Traz } \\
\text { depoimento de Saldiva, em relação aos } \\
\text { benefícios da prática de exercícios físicos } \\
\text { e a prática destes em locais com alto } \\
\text { índice de poluentes atmosféricos. }\end{array}$ \\
\hline 2005 & $\begin{array}{l}\text { Jornal } \\
\text { Folha de } \\
\text { S.Paulo }\end{array}$ & $\begin{array}{l}\text { Caminho da } \\
\text { poluição: ciclovia } \\
\text { na marginal }\end{array}$ & $\begin{array}{l}\text { Reportagem sobre a implantação de } \\
\text { ciclovia e considerações de Saldiva em } \\
\text { relação ao assunto. }\end{array}$ \\
\hline \begin{tabular}{l|}
2005 \\
$26 /$ nov
\end{tabular} & $\begin{array}{l}\text { Site } \mathrm{O} \\
\text { Eco } \mathrm{LXXXI}\end{array}$ & $\begin{array}{l}\text { Termômetro } \\
\text { vegetal }\end{array}$ & $\begin{array}{l}\text { Entrevista com Saldiva. Trata de estudos } \\
\text { de biomonitoramento atmosférico através } \\
\text { do tronco de árvores. }\end{array}$ \\
\hline
\end{tabular}

LXXIX Caderno Ciência.

LXXX Caderno Ciência.

LXXXI Disponível em http://www.oeco.com.br/oeco 


\begin{tabular}{|c|c|c|c|}
\hline DATA & $\mathrm{VC}^{*}$ & TÍTULO & ASSUNTO \\
\hline $\begin{array}{l}2005 \\
22 / d e z\end{array}$ & $\begin{array}{l}\text { Jornal } \\
\text { Folha de } \\
\text { S.Paulo }\end{array}$ & $\begin{array}{l}\text { Sinais de infertili- } \\
\text { dade no ar }\end{array}$ & $\begin{array}{l}\text { Trata da pesquisa realizada pelo LPAE } \\
\text { que analisou a associação de infertilidade } \\
\text { com poluição atmosférica. }\end{array}$ \\
\hline $\begin{array}{l}2006 \\
21 / j a n\end{array}$ & Site O Eco & Veneno de verão & $\begin{array}{l}\text { Matéria sobre produção de ozônio nos } \\
\text { dias de calor e sua correlação com } \\
\text { problemas de saúde. Traz parecer de } \\
\text { Saldiva sobre o assunto. }\end{array}$ \\
\hline $\begin{array}{l}2006 \\
02 / f e v\end{array}$ & $\begin{array}{l}\text { Jornal } \\
\text { Folha de } \\
\text { S.Paulo }\end{array}$ & $40^{\circ} \mathrm{C}$ à sombra & $\begin{array}{l}\text { Trata das questões envolvendo poluição } \\
\text { atmosférica e saúde em dias de }\end{array}$ \\
\hline & $\begin{array}{l}\text { Site Folha } \\
\text { On Line }\end{array}$ & $\begin{array}{l}\text { Veja } 40 \text { efeitos } \\
\text { do calor e dicas } \\
\text { para se manter } \\
\text { saudável }\end{array}$ & $\begin{array}{l}\text { excessivo calor. Apresenta Saldiva com o } \\
\text { um dos colaboradores para a matéria. }\end{array}$ \\
\hline $\begin{array}{l}2006 \\
24 / a b r\end{array}$ & $\begin{array}{l}\text { Jornal O } \\
\text { Estado de } \\
\text { S.Paulo }\end{array}$ & $\begin{array}{l}\text { Queima de cana } \\
\text { aumenta } \\
\text { problemas } \\
\text { respiratórios }\end{array}$ & $\begin{array}{l}\text { Trata do assunto do título nas regiões de } \\
\text { como Araraquara, Ribeirão Preto e } \\
\text { Piracicaba (SP) a partir de informações } \\
\text { de Marcos Arbex. }\end{array}$ \\
\hline $\begin{array}{l}2006 \\
12 / \text { mai }\end{array}$ & $\begin{array}{l}\text { Jornal O } \\
\text { Estado de } \\
\text { S.Paulo }\end{array}$ & $\begin{array}{l}\text { É tempo de se } \\
\text { proteger da } \\
\text { poluição }\end{array}$ & $\begin{array}{l}\text { Aborda várias questões envolvendo saú- } \\
\text { de e poluição. Cita a pesquisa do LPAE } \\
\text { que relacionou aumento da poluição ao } \\
\text { crescimento da mortalidade de fetos. } \\
\text { Traz J.E. Cançado como "fonte de } \\
\text { informação". }\end{array}$ \\
\hline $\begin{array}{l}2006 \\
27 / \text { mai }\end{array}$ & Site O Eco & $\begin{array}{l}\text { Cidade } \\
\text { envenenada }\end{array}$ & $\begin{array}{l}\text { Aborda o Programa de Controle de } \\
\text { Poluição do Ar por Veículos Automotores } \\
\text { (Proconve). Traz depoimento de Saldiva } \\
\text { sobre os benefícios do Programa } \\
\text { aplicado em Belo Horizonte/MG. }\end{array}$ \\
\hline \multirow[t]{2}{*}{$\begin{array}{l}2006 \\
12 / j u n\end{array}$} & $\begin{array}{l}\text { Jornal da } \\
\text { Ciência } \\
\text { LXXXII }\end{array}$ & \multirow[t]{2}{*}{$\begin{array}{l}\text { Filtro contra a } \\
\text { poluição do ar }\end{array}$} & \multirow{2}{*}{$\begin{array}{l}\text { Artigo sobre um filtro desenvolvido pelo } \\
\text { engenheiro Sergio Sangiovani em parce- } \\
\text { ria com o LPAE que pretende barrar os } \\
\text { materiais particulados finos emitidos pe- } \\
\text { los veículos. Traz comentários de Paulo } \\
\text { A. de André, pesquisador do LPAE, como } \\
\text { um dos participantes do trabalho. }\end{array}$} \\
\hline & $\begin{array}{l}\text { Site } \\
\text { Agência } \\
\text { Fapesp de } \\
\text { Notícia }\end{array}$ & & \\
\hline $\begin{array}{l}2006 \\
21 / j u n\end{array}$ & $\begin{array}{l}\text { Jornal O } \\
\text { Estado de } \\
\text { S.Paulo }\end{array}$ & $\begin{array}{l}\text { Proteja-se dos } \\
\text { males da polui- } \\
\text { ção para o corpo } \\
\text { humano. }\end{array}$ & $\begin{array}{l}\text { Republicação de reportagem "É tempo de } \\
\text { se proteger da poluição" ( }{ }^{\circ 17} \text { ) veiculada } \\
\text { em } 12 / 05 / 2006\end{array}$ \\
\hline $\begin{array}{l}2006 \\
12 / j u l\end{array}$ & $\begin{array}{l}\text { Jornal O } \\
\text { Estado de } \\
\text { S.Paulo }\end{array}$ & $\begin{array}{l}\text { Engenheiro cria } \\
\text { filtro contra } \\
\text { poluição do ar }\end{array}$ & $\begin{array}{l}\text { Artigo sobre um filtro desenvolvido em } \\
\text { parceria com o LPAE que pretende barrar } \\
\text { os materiais particulados finos emitidos } \\
\text { pelos veículos. }\end{array}$ \\
\hline
\end{tabular}

LXXXII Jornal da Sociedade Brasileira para o Progresso da Ciência. 


\begin{tabular}{|c|c|c|c|}
\hline DATA & VC* & TÍTULO & ASSUNTO \\
\hline $\begin{array}{l}2006 \\
15 / j u l\end{array}$ & Site O Eco & $\begin{array}{l}\text { Desfazendo a } \\
\text { má fama }\end{array}$ & $\begin{array}{l}\text { Trata dos programas de monitoramento } \\
\text { de poluição atmosférico em diferentes ci- } \\
\text { Dades. Traz depoimento de Saldiva } \\
\text { comparando o programa da cidade de } \\
\text { S.Paulo ao de outras cidades brasileiras. }\end{array}$ \\
\hline $\begin{array}{l}2006 \\
23 / \text { ago }\end{array}$ & $\begin{array}{l}\text { Jornal } \\
\text { Folha de } \\
\text { S.Paulo }\end{array}$ & $\begin{array}{l}\text { Ar seco deixa } \\
\text { Ribeirão em } \\
\text { emergência pelo } \\
2^{\circ} \text { dia }\end{array}$ & $\begin{array}{l}\text { Trata do assunto do título e as } \\
\text { conseqüências para a saúde a partir da } \\
\text { informações de Luiz A. Pereira. }\end{array}$ \\
\hline $\begin{array}{l}2006 \\
01 / \text { set }\end{array}$ & Site O Eco & Plantas cobaias & $\begin{array}{l}\text { Matéria sobre o programa de monitora- } \\
\text { mento da qualidade do ar implantado em } \\
\text { S.José dos Campos (SP). Traz explica- } \\
\text { ções de Saldiva sobre o assunto. }\end{array}$ \\
\hline $\begin{array}{l}2006 \\
12 / \text { set }\end{array}$ & $\begin{array}{l}\text { Jornal } \\
\text { Diário de } \\
\text { S.Paulo }\end{array}$ & $\begin{array}{l}\text { Poluição } \\
\text { transforma fiscal } \\
\text { do trânsito em } \\
\text { "fumante virtual" }\end{array}$ & $\begin{array}{l}\text { Refere-se ao estudo do LPAE sobre a ex- } \\
\text { posição de trabalhadores da CET à fuma- } \\
\text { ça dos veículos e sua correlação com en } \\
\text { fartes e doenças respiratórias. Traz depoi } \\
\text { mento de Alfésio Braga. }\end{array}$ \\
\hline $\begin{array}{l}2006 \\
15 / \text { set }\end{array}$ & $\begin{array}{l}\text { Jornal } \\
\text { Diário de } \\
\text { S.Paulo }\end{array}$ & $\begin{array}{l}\text { Estudo aponta } \\
\text { que poluição é } \\
\text { tão nociva } \\
\text { quanto o cigarro }\end{array}$ & $\begin{array}{l}\text { Refere-se ao estudo do sobre a exposi- } \\
\text { ção de trabalhadores da CET à fumaça } \\
\text { dos veículos e sua correlação com en- } \\
\text { fartes e doenças respiratórias, paradas } \\
\text { cardíacas. }\end{array}$ \\
\hline $\begin{array}{l}2006 \\
19 / \text { set }\end{array}$ & $\begin{array}{l}\text { Site Folha } \\
\text { On Line }\end{array}$ & $\begin{array}{l}\text { Poluição por } \\
\text { ozônio aumenta } \\
\text { problemas } \\
\text { respiratórios }\end{array}$ & $\begin{array}{l}\text { Matéria sobre produção de ozônio } \\
\text { correlacionado a problemas respiratórios. } \\
\text { Traz parecer de Saldiva. }\end{array}$ \\
\hline $\begin{array}{l}2006 \\
21 / \text { set }\end{array}$ & $\begin{array}{l}\text { Jornal O } \\
\text { Estado de } \\
\text { S.Paulo }\end{array}$ & $\begin{array}{l}\text { Dia sem carro: } \\
\text { chance para } \\
\text { usar ônibus, me- } \\
\text { trô e até bicicleta }\end{array}$ & $\begin{array}{l}\text { Refere-se à campanha realizada pelo go- } \\
\text { verno municipal de S.Paulo onde a popu- } \\
\text { lação é incentivada a deixar o carro e } \\
\text { buscar alternativas de locomoção. Faz re- } \\
\text { ferência às pesquisas do LPAE sobre } \\
\text { emissões de gases tóxicos veiculares. } \\
\text { Correlaciona com problemas de saúde. }\end{array}$ \\
\hline $\begin{array}{l}2006 \\
\text { out }\end{array}$ & $\begin{array}{l}\text { Revista } \\
\text { Alphanews }\end{array}$ & $\begin{array}{l}\text { Em busca da } \\
\text { verdade sobre o } \\
\text { mau cheiro }\end{array}$ & $\begin{array}{l}\text { Aborda os malefícios á saúde provocados } \\
\text { pela poluição sob influência do rio Tietê. } \\
\text { Traz depoimento de Saldiva. }\end{array}$ \\
\hline $\begin{array}{l}2006 \\
14 / \text { out }\end{array}$ & $\begin{array}{l}\text { Jornal O } \\
\text { Estado de } \\
\text { S.Paulo }\end{array}$ & $\begin{array}{l}\text { Álcool - o melhor } \\
\text { substituto do } \\
\text { petróleo }\end{array}$ & $\begin{array}{l}\text { Trata das vantagens ambientais do álcool } \\
\text { combustível. Menciona os trabalhos do } \\
\text { LPAE quando da estruturação do } \\
\text { Proálcool. }\end{array}$ \\
\hline $\begin{array}{l}2006 \\
27 / \text { out }\end{array}$ & $\begin{array}{l}\text { Jornal A } \\
\text { Tribuna }\end{array}$ & $\begin{array}{l}\text { Sentinela } \\
\text { Ambiental }\end{array}$ & $\begin{array}{l}\text { Reportagem sobre os trabalhos de Nilva } \\
\text { Campina com alunos de Ensino Básico } \\
\text { em Cubatão para o biomonitoramento do } \\
\text { ar e da água do rio. }\end{array}$ \\
\hline & & & \\
\hline
\end{tabular}




\begin{tabular}{|c|c|c|c|}
\hline DATA & $\mathrm{VC}^{*}$ & TÍTULO & ASSUNTO \\
\hline $\begin{array}{l}2006 \\
\text { nov }\end{array}$ & $\begin{array}{l}\text { Revista } \\
\text { Espaço } \\
\text { Aberto }\end{array}$ & $\begin{array}{l}\text { OMS altera } \\
\text { níveis mínimos } \\
\text { para a poluição } \\
\text { do ar }\end{array}$ & $\begin{array}{l}\text { Trata da mudança dos padrões de quali- } \\
\text { dade do ar estabelecidos pela OMS } \\
\text { ApxXIII. } \\
\text { pesquisadores brasileiros a participar des } \\
\text { te comitê. Correlaciona saúde e mortalida } \\
\text { de à poluição. }\end{array}$ \\
\hline \multirow[t]{3}{*}{$\begin{array}{l}2006 \\
08 / \text { nov }\end{array}$} & $\begin{array}{l}\text { Jornal O } \\
\text { Estado de } \\
\text { S.Paulo }\end{array}$ & $\begin{array}{l}\text { OMS muda regra } \\
\text { e SP fica mais } \\
\text { poluída }\end{array}$ & \multirow{3}{*}{$\begin{array}{l}\text { Trata da mudança dos padrões de } \\
\text { qualidade do ar estabelecidos pela OMS. } \\
\text { Apresenta Saldiva como um dos autores } \\
\text { do novo guia e discorre sobre questões } \\
\text { como saúde e mortalidade associadas à } \\
\text { poluição. }\end{array}$} \\
\hline & $\begin{array}{l}\text { Jornal } \\
\text { Diário de } \\
\text { S.Paulo }\end{array}$ & $\begin{array}{l}\text { OMS muda regra } \\
\text { e cidade de São } \\
\text { Paulo fica mais } \\
\text { poluída }\end{array}$ & \\
\hline & $\begin{array}{l}\text { Site Folha } \\
\text { On Line }\end{array}$ & $\begin{array}{l}\text { OMS muda } \\
\text { padrões para } \\
\text { poluição do ar }\end{array}$ & \\
\hline $\begin{array}{l}2006 \\
09 / \text { nov }\end{array}$ & $\begin{array}{l}\text { Jornal } \\
\text { Folha de } \\
\text { S.Paulo }\end{array}$ & $\begin{array}{l}\text { Novos limites da } \\
\text { OMS para polui- } \\
\text { ção atmosférica } \\
\text { colocam o país } \\
\text { em alerta }\end{array}$ & $\begin{array}{l}\text { Trata da mudança dos padrões de quali- } \\
\text { dade do ar estabelecidos pela OMS.Traz } \\
\text { comentários de Saldiva. Correlaciona } \\
\text { questões como saúde e mortalidade } \\
\text { associadas à poluição. }\end{array}$ \\
\hline $\begin{array}{l}2006 \\
22 / \text { nov }\end{array}$ & $\begin{array}{l}\text { Revista } \\
\text { Veja }\end{array}$ & $\begin{array}{l}\text { Para abraçar a } \\
\text { causa verde }\end{array}$ & $\begin{array}{l}\text { Traz vários comentários que envolvem po } \\
\text { luição e atividades que podem ser pratica } \\
\text { das pelos cidadãos para minimizá-la.Traz } \\
\text { Saldiva como um exemplo por se locomo } \\
\text { por S.Paulo com um patinete. }\end{array}$ \\
\hline $\begin{array}{l}2006 \\
09 / d e z\end{array}$ & $\begin{array}{l}\text { Jornal O } \\
\text { Estado de } \\
\text { S.Paulo }\end{array}$ & $\begin{array}{l}\text { Stress no tráfego } \\
\text { é problema de } \\
\text { saúde pública }\end{array}$ & $\begin{array}{l}\text { Trata do assunto do título e traz depoi- } \\
\text { mento de Saldiva com vários dados sobre } \\
\text { poluicão de automóveis e saúde. }\end{array}$ \\
\hline $\begin{array}{l}2006 \\
30 / d e z\end{array}$ & Site O Eco & $\begin{array}{l}\text { "Veneno" } \\
\text { anunciado }\end{array}$ & $\begin{array}{l}\text { Trata sobre um programa de mapeamen- } \\
\text { to de poluentes atmosféricos na cidade } \\
\text { de S.Paulo. Traz depoimento de Saldiva } \\
\text { referente à necessidade de redução do } \\
\text { tráfego na cidade. }\end{array}$ \\
\hline $\begin{array}{l}2006 \\
31 / \text { dez }\end{array}$ & $\begin{array}{l}\text { Jornal O } \\
\text { Estado de } \\
\text { S.Paulo }\end{array}$ & $\begin{array}{l}\text { China é um } \\
\text { péssimo } \\
\text { exemplo }\end{array}$ & $\begin{array}{l}\text { Aborda a questão do crescimento econô- } \\
\text { mico da China sem respeitar os limites } \\
\text { ambientais. Faz referência ao LPAE e } \\
\text { traz comentário de Saldiva sobre estudos } \\
\text { do efeito da poluição em S.Paulo e a } \\
\text { diminuição da expectativa de vida. }\end{array}$ \\
\hline $\begin{array}{l}2007 \\
01 / \text { jan }\end{array}$ & $\begin{array}{l}\text { Jornal Todo } \\
\text { Dia }\end{array}$ & $\begin{array}{l}\text { Queima reduz } \\
\text { qualidade do ar }\end{array}$ & $\begin{array}{l}\text { Refere-se às queimadas na região de } \\
\text { Campinas (SP) e a alteração da } \\
\text { qualidade do ar. Cita estudos do LPAE } \\
\text { relacionados ao assunto. }\end{array}$ \\
\hline
\end{tabular}

LXXXIII Organização Mundial de Saúde

LXXXIV Jornal de circulação na região metropolitana de Campinas 


\begin{tabular}{|c|c|c|c|}
\hline DATA & VC* & TÍTULO & ASSUNTO \\
\hline $\begin{array}{l}2007 \\
\text { jan }\end{array}$ & $\begin{array}{l}\text { Revista } \\
\text { Claudia } \\
\text { LXXXV }\end{array}$ & $\begin{array}{l}\text { Poluição: como } \\
\text { proteger a sua } \\
\text { saúde }\end{array}$ & $\begin{array}{l}\text { Trata do assunto do título e traz } \\
\text { entrevista com Saldiva. }\end{array}$ \\
\hline $\begin{array}{l}\text { 2007- } \\
11 / \text { jan }\end{array}$ & Site O Eco & $\begin{array}{l}\text { O buraco é mais } \\
\text { embaixo }\end{array}$ & $\begin{array}{l}\text { Matéria sobre a aprovação de resolução } \\
\text { pelo Conama } \\
\text { parâmetros para as emissões de } \\
\text { chaminés,caldeiras e fornos industriais. } \\
\text { Traz parecer de Saldiva sobre o assunto. }\end{array}$ \\
\hline $\begin{array}{l}2007 \\
14 / \text { jan }\end{array}$ & $\begin{array}{l}\text { Jornal } \\
\text { Folha de } \\
\text { S.Paulo }\end{array}$ & Cidades imóveis & $\begin{array}{l}\text { Matéria sobre poluição atmosférica nas } \\
\text { grandes cidades. Traz depoimento de } \\
\text { Saldiva. }\end{array}$ \\
\hline $\begin{array}{l}2007 \\
04 / \mathrm{fev}\end{array}$ & $\begin{array}{l}\text { Jornal Todo } \\
\text { Dia }\end{array}$ & $\begin{array}{l}\text { País ocupa lugar } \\
\text { preocupante na } \\
\text { poluição do ar, } \\
\text { revela a OMS }\end{array}$ & $\begin{array}{l}\text { Trata de estudo da Organização Mundial } \\
\text { de Saúde sobre poluição atmosférica } \\
\text { correlacionados à saúde. Cita trabalhos } \\
\text { do LPAE. }\end{array}$ \\
\hline $\begin{array}{l}2007 \\
14 / \mathrm{fev}\end{array}$ & $\begin{array}{l}\text { Site } \\
\text { Agência } \\
\text { USP de } \\
\text { Notícias } \\
\text { LXXXVII }\end{array}$ & $\begin{array}{l}\text { Poluição é a } \\
\text { grande causa da } \\
\text { diminuição de } \\
\text { nascimentos } \\
\text { masculinos em } \\
\text { S.Paulo }\end{array}$ & $\begin{array}{l}\text { Matéria sobre o assunto do título, } \\
\text { referindo-se ao trabalho de Ana Júlia } \\
\text { Lichtenfels. }\end{array}$ \\
\hline $\begin{array}{l}2007 \\
11 / \text { mar }\end{array}$ & $\begin{array}{l}\text { Jornal } \\
\text { Folha de } \\
\text { S.Paulo }\end{array}$ & $\begin{array}{l}\text { Fumaça preta dá } \\
\text { multa de } R \$ \\
854,00\end{array}$ & $\begin{array}{l}\text { Refere-se à multa por emanação de ga- } \\
\text { ses tóxicos. Traz parecer de Luiz A. Pe- } \\
\text { reira correlacionado o assunto às quês- } \\
\text { tões de saúde. }\end{array}$ \\
\hline $\begin{array}{l}2007 \\
16 / \text { mar }\end{array}$ & $\begin{array}{l}\text { Jornal A } \\
\text { Tribuna }\end{array}$ & $\begin{array}{l}\text { Cientistas vão } \\
\text { estudar efeitos } \\
\text { da poluição }\end{array}$ & $\begin{array}{l}\text { Refere-se à pesquisa EEPRBS - } \\
\text { Estuário. Cita a parceria deste estudo } \\
\text { com escolas de Ensino Básico e Técnico } \\
\text { da Baixada Santista. Traz esclarecimen- } \\
\text { tos de Alfésio Braga e Mônica } \\
\text { Lobarinhas. }\end{array}$ \\
\hline $\begin{array}{l}2007 \\
28 / \text { mar }\end{array}$ & $\begin{array}{l}\text { Site Folha } \\
\text { On Line }\end{array}$ & $\begin{array}{l}\text { Baixa umidade do ar } \\
\text { deixa São Paulo em } \\
\text { alerta; temperatura } \\
\text { chega a } 35,1^{\circ} \mathrm{C}\end{array}$ & \multirow{2}{*}{$\begin{array}{l}\text { Trata do assunto do título e traz } \\
\text { parecer de Marcos Arbex que o } \\
\text { correlaciona a problemas de saúde. }\end{array}$} \\
\hline \multirow[t]{2}{*}{$\begin{array}{l}2007 \\
29 / \text { mar }\end{array}$} & $\begin{array}{l}\text { Site Folha } \\
\text { On Line }\end{array}$ & $\begin{array}{l}\text { São Paulo tem } \\
\text { qualidade do ar } \\
\text { regular; umidade do } \\
\text { ar fica em } 25 \%\end{array}$ & \\
\hline & $\begin{array}{l}\text { Jornal } \\
\text { Setecidade } \\
\text { s - Diário } \\
\text { do Grande } \\
\text { ABC }\end{array}$ & $\begin{array}{l}\text { Cetesb } \\
\text { questiona } \\
\text { despoluição do } \\
\text { Barão }\end{array}$ & $\begin{array}{l}\text { Matéria sobre o condomínio Barão de } \\
\text { Mauá cujo terreno sofreu contaminação } \\
\text { de lixo industrial. Refere-se à Saldiva } \\
\text { como "um dos maiores toxicologistas do } \\
\text { Brasil", responsável pelas análises no } \\
\text { solo do condomínio. }\end{array}$ \\
\hline
\end{tabular}

LXXXV Edição 544.

LXXXVI

LXXXVII Disponível em http://www.usp.br/agen/UOLhome.php 


\begin{tabular}{|c|c|c|c|}
\hline DATA & VC* & TÍTULO & ASSUNTO \\
\hline $\begin{array}{l}2007 \\
a b r\end{array}$ & $\begin{array}{l}\text { Revista do } \\
\text { Brasil }^{\text {LXXXVIII }}\end{array}$ & Pedala, Brasil! & $\begin{array}{l}\text { Trata do crescente número de usuários } \\
\text { de bicicleta, correlacionando às questões } \\
\text { econômicas, ambientais e à saúde. Traz } \\
\text { parecer de Saldiva. }\end{array}$ \\
\hline $\begin{array}{l}2007 \\
23 / a b r\end{array}$ & $\begin{array}{l}\text { Jornal O } \\
\text { Estado de } \\
\text { S.Paulo }\end{array}$ & $\begin{array}{l}\text { Poluição causa } 7 \\
\text { mortes por dia }\end{array}$ & $\begin{array}{l}\text { Cita entrevista de Saldiva na qual este } \\
\text { discorre sobre a correlação entre } \\
\text { poluição atmosférica e redução da } \\
\text { expectativa de vida do paulistano. }\end{array}$ \\
\hline $\begin{array}{l}2007 \\
28 / a b r\end{array}$ & $\begin{array}{l}\text { Jornal O } \\
\text { Estado de } \\
\text { S.Paulo }\end{array}$ & $\begin{array}{l}\text { Um em cada três } \\
\text { carros de SP po- } \\
\text { lui em excesso }\end{array}$ & $\begin{array}{l}\text { Matéria sobre a venda de catalisador } \\
\text { irregular e as conseqüências para o meio } \\
\text { ambiente. Traz parecer de Saldiva. }\end{array}$ \\
\hline $\begin{array}{l}2007 \\
\text { mai }\end{array}$ & $\begin{array}{l}\text { Revista } \\
\text { Saúde! é } \\
\text { vital }\end{array}$ & $\begin{array}{l}\text { O ar nosso de } \\
\text { cada dia }\end{array}$ & $\begin{array}{l}\text { Trata sobre poluição nas metrópoles e } \\
\text { nas cidades pequenas também sofrem a } \\
\text { ação dos gases venenosos. Traz parecer } \\
\text { de Alfésio Braga com esclarecimentos } \\
\text { sobre as conseqüências para a saúde. }\end{array}$ \\
\hline \multirow[t]{2}{*}{$\begin{array}{l}2007 \\
15 / \text { mai }\end{array}$} & \multirow[t]{2}{*}{$\begin{array}{l}\text { Jornal } \\
\text { Folha de } \\
\text { S.Paulo }\end{array}$} & $\begin{array}{l}\text { Pólo cerâmico } \\
\text { de SP, Santa } \\
\text { Gertrudes sofre } \\
\text { com poluição }\end{array}$ & $\begin{array}{l}\text { Trata do assunto do título em relação à } \\
\text { poluição industrial da região. Traz } \\
\text { parecer de Saldiva. }\end{array}$ \\
\hline & & $\begin{array}{l}\text { Qualidade do ar } \\
\text { melhora em SP, } \\
\text { mas segue ruim }\end{array}$ & $\begin{array}{l}\text { Refere-se à queda da poluição por ozônio } \\
\text { constatado pelo Proconve (programa fé- } \\
\text { deral de controle da poluição por veícu- } \\
\text { los) e análise de Saldiva sobre o assunto. }\end{array}$ \\
\hline \multirow[t]{2}{*}{$\begin{array}{l}2007 \\
17 / \text { mai }\end{array}$} & $\begin{array}{l}\text { Jornal O } \\
\text { Estado de } \\
\text { S.Paulo }\end{array}$ & $\begin{array}{l}\text { Poluição é tão } \\
\text { grosseira que } \\
\text { filtro já ajuda, diz } \\
\text { expert }\end{array}$ & \multirow{2}{*}{$\begin{array}{l}\text { Artigo sobre um filtro desenvolvido pelo } \\
\text { engenheiro Sergio Sangiovani em } \\
\text { parceria com o LPAE que pretende } \\
\text { barrar, logo após a emissão feita pelos } \\
\text { motores, os materiais particulados finos. } \\
\text { Traz comentários de Paulo Alfonso de } \\
\text { André, pesquisador do LPAE, como um } \\
\text { dos participantes do trabalho. }\end{array}$} \\
\hline & $\begin{array}{l}\text { Jornal } \\
\text { Diário de } \\
\text { S.Paulo }\end{array}$ & $\begin{array}{l}\text { Uso de filtro } \\
\text { diminuiria } \\
\text { poluição, diz } \\
\text { engenheiro }\end{array}$ & \\
\hline \multirow[t]{2}{*}{$\begin{array}{l}2007 \\
24 / \text { mai }\end{array}$} & $\begin{array}{l}\text { Jornal O } \\
\text { Estado de } \\
\text { S.Paulo }\end{array}$ & $\begin{array}{l}\text { Carros terão } \\
\text { inspeção } \\
\text { ambiental }\end{array}$ & \multirow{2}{*}{$\begin{array}{l}\text { Matéria sobre a implantação, pelo } \\
\text { governo municipal, do projeto de } \\
\text { inspeção veicular ambiental. } \\
\text { Cita Saldiva como participante do evento. }\end{array}$} \\
\hline & $\begin{array}{l}\text { Jornal } \\
\text { Diário de } \\
\text { S.Paulo }\end{array}$ & $\begin{array}{l}\text { Veículos de SP } \\
\text { vão passar por } \\
\text { inspeção } \\
\text { ambiental }\end{array}$ & \\
\hline $\begin{array}{l}2007 \\
02 / j u n\end{array}$ & $\begin{array}{l}\text { Jornal O } \\
\text { Estado de } \\
\text { S.Paulo }\end{array}$ & $\begin{array}{l}\text { Operação Inver- } \\
\text { no avaliará } 25 \% \\
\text { dos veículos a } \\
\text { diesel }\end{array}$ & $\begin{array}{l}\text { Trata da } 20^{\text {a }} \text { edição da Operação Inverno } \\
\text { lançada pelo Governo do Estado de São } \\
\text { Paulo com o objetivo de diminuir a polui- } \\
\text { ção causada pelos veículos a diesel. Traz } \\
\text { parecer de Saldiva correlacionado o } \\
\text { assunto à saúde. }\end{array}$ \\
\hline
\end{tabular}

LXXXVIII Edição no 11. 


\begin{tabular}{|c|c|c|c|}
\hline DATA & $\mathrm{VC}^{*}$ & TÍTULO & ASSUNTO \\
\hline $\begin{array}{l}2007 \\
03 / \text { jun }\end{array}$ & $\begin{array}{l}\text { Jornal } \\
\text { Setecidade } \\
\text { s Diário do } \\
\text { Grande } \\
\text { ABC }\end{array}$ & $\begin{array}{l}1 \text { o ônibus } \quad \text { a } \\
\text { hidrogênio virá } \\
\text { para região }\end{array}$ & $\begin{array}{l}\text { Artigo sobre o primeiro ônibus a } \\
\text { hidrogênio do Brasil a ser utilizado na } \\
\text { cidade de S.Paulo. Traz parecer de } \\
\text { Saldiva com avaliações positivas sobre o } \\
\text { novo veículo. }\end{array}$ \\
\hline $\begin{array}{l}2007 \\
07 / \text { jun }\end{array}$ & $\begin{array}{l}\text { Jornal O } \\
\text { Estado de } \\
\text { S.Paulo }\end{array}$ & $\begin{array}{l}\text { A queimada dos } \\
\text { canaviais }\end{array}$ & $\begin{array}{l}\text { Trata sobre a redução do prazo } \\
\text { estabelecido por lei para eliminação das } \\
\text { queimadas de canaviais no estado de } \\
\text { São Paulo. Traz depoimento de José } \\
\text { Eduardo Cançado referindo-se a estudos } \\
\text { que correlacionam queimadas e } \\
\text { conseqüências à saúde. }\end{array}$ \\
\hline $\begin{array}{l}2007 \\
28 / \text { jun }\end{array}$ & Site O Eco & $\begin{array}{l}\text { Sampa em duas } \\
\text { rodas }\end{array}$ & $\begin{array}{l}\text { Aborda o uso das bicicletas nas grandes } \\
\text { cidade S. Entrevista com P. "Saldiva que } \\
\text { fala sobre este veículo, sua importância } \\
\text { ambiental, educativa e de saúde". }\end{array}$ \\
\hline $\begin{array}{l}2007 \\
29 / \text { jun }\end{array}$ & Site O Eco & $\begin{array}{l}\text { Controvérsia no } \\
\text { ar }\end{array}$ & $\begin{array}{l}\text { Refere-se ao programa de inspeção } \\
\text { veicular em andamento na cidade de } \\
\text { S.Paulo. Traz depoimento de Saldiva em } \\
\text { desacordo com as declarações do } \\
\text { prefeito da cidade em relação aos } \\
\text { benefícios do programa. }\end{array}$ \\
\hline
\end{tabular}

* VC - veículo de comunicação 


\section{ANEXO D}

Projetos elaborados pelos professores na última aula do curso PoSPAE

\section{Projeto 1}

\section{Tema: Poluição em Áreas de Manguezais}

Escola(s): EMEF ${ }^{L X X X I X}$ Martim Afonso de Souza e EMEF Ruy Barbosa.

Justificativa: contato direto de alunos e famílias com áreas de manguezal, executando várias atividades: lazer, esporte, alimentação, trabalho, moradia.

- percepção de poluição por esgotos domésticos, lixo urbano e resíduos industriais em toda a região pesquisada;

- diversos casos de agravos à saúde como: doenças de pele, alergias, deficiência visual, sistema nervoso, câncer, alterações genéticas, abortos.

Objetivo(s) específico(s): 1. identificar possíveis bioindicadores de rios, manguezais e mata ciliar; 2 . analisar os materiais coletados quanto a sua quantificação/qualificação; 3. correlacionar os dados obtidos com as interferências na saúde da população.

Plano de ação (metodologia, conteúdos, atividades): 1. mapear fontes poluidoras e aspectos geográficos da região; 2. pesquisar trabalhos anteriores sobre o tema em diversos meios: Internet, bibliotecas, etc.; 3. apresentação do projeto à comunidade escolar; 4. levantamento de dados junto à população para verificar hábitos de doenças; 5 . tabulação de dados obtidos; 6. pesquisar anomalias em vísceras animais e vegetais habitantes da região 7. testar possíveis "novos bioindicadores" em vegetais e animais

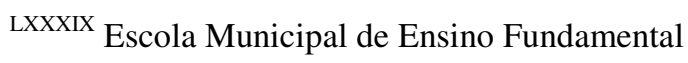




\section{Projeto 2}

Escola(s): EMEF João Ramalho (Cubatão) , EM ${ }^{\mathrm{XC}}$ São Francisco de Assis (Praia Grande) e $\mathrm{EE}^{\mathrm{XCl}}$ Praia de Boracéia (Bertioga).

Tema: Ozônio, mocinho ou bandido?

Justificativa: Estudos em região de mata mostram experimentalmente que há um aumento acentuado de $\mathrm{O} 3$ na atmosfera, podendo causar efeitos biológicos não identificados totalmente.

Objetivo(s) específico(s): : identificar a presença de gás Ozônio nas atmosferas de Santos e Bertioga, verificando se as concentrações são significativas.

\section{Plano de ação (metodologia, conteúdos, atividades):}

1. pesquisa teórica; 2. ensaios experimentais envolvendo bioindicadores (folha de tabaco); 3. leitura dos resultados - folha de tabaco; tabulação de dados; elaboração de relatórios.

\section{Projeto 3}

Escola(s): EMEF Prof. Dr. Luiz Pieruzzi Netto, EE Ignácio Miguel Estefani, EMEF D.Pedro I e EMEF Luiz Gustavo de Lima.

Tema: Contaminação de horta via solo.

Justificativa: $\mathrm{O}$ cultivo de hortas é um hábito comum entre os moradores da comunidade

Objetivo(s) específico(s): identificar algum poluente no solo utilizado para cultivo da horta.

Plano de ação (metodologia, conteúdos, atividades): 1. identificar três pontos diferentes de cultivo - obs.: uma das hortas tem o solo fornecido por 
uma empresa patrocinadora. 2. providencias as mudas de Tradescantia; 3. plantar as mudas; 4. acompanhar até o ponto de coleta das inflorescências para identificação das anomalias; 5. coleta para leitura e leitura; 6. conclusão.

\section{Projeto 4}

Escola(s): EMEF Pde. José de Anchieta EMEF João Ramalho.

Tema: Estudar e correlacionar problemas respiratórios com a qualidade do ar; Estudo Epidemiológico de problemas respiratórios

Justificativa: perceber como a interferência no meio ambiente, causada pela poluição pode afetar diretamente a saúde da população dessa região, considerando que os problemas respiratórios podem estar ligados à poluição e que as crianças são as mais afetadas por essa interferência.

Objetivo(s) específico(s): nada consta

Plano de ação (metodologia, conteúdos, atividades): estudo epidemiológico:a) análise de dados secundários de policlínicas - entrada de bebês e crianças por problemas respiratórios;b) comparar com os índices de poluição no mesmo período.

\section{Projeto 5}

Escola(s): EE José da Costa.

Tema: Contaminação por Hg (mercúrio) nas águas do rio Cubatão.

Justificativa: mostrar para os alunos que a exposição às águas contaminadas por $\mathrm{Hg}$ provoca danos à saúde.

Objetivo(s) específico(s): nada consta 
Plano de ação (metodologia, conteúdos, atividades): 1. coletar material para análise; 2. verificar a origem do material; 3. identificação da composição química na amostra.

Conteúdos: gráficos, tabelas, fotos, probabilidades, estatísticas, reações químicas envolvidas, estudo biológico.

Atividades: 1. pesquisa sobre a história dos materiais; 2. construções de gráficos e tabelas através de levantamento de dados; 3. interferências do clima (temperatura, nos ventos) informação, amostragens.

\section{Projeto 6}

Escola(s): EMEF João Ramalho (Cubatão) EE Parque das Bandeiras Gleba II (São Vicente)

Tema: Contaminação do solo por organoclorados provenientes do lixão da Rhodia

Justificativa: devido ao índice de degradação o organoclorado é um composto que se mantém no ambiente durante várias décadas podendo comprometer o solo e a saúde de uma população próxima.

Objetivos: baseado em estudos com Tradescantia, analisar o solo da região para saber o grau de degradação por esse composto.

Plano de ação (metodologia, conteúdos, atividades):

metodologia: bioensaio de micronúcleo;

conteúdo: solo: poluição, técnicas para plantio de Tradescantia;

atividades: manuseio do microscópio; plantio de Tradescantia; análise de lâmina; interpretação de resultados. 


\section{Projeto 7}

Local: NEA - Núcleo de Educação Ambiental (Cubatão)

Tema: Bioindicadores e Metodologia Científica aplicada para educandos que fazem visita monitorada no Parque Ecológico Cotia Pará.

Justificativa: possibilitar que os educandos conheçam na prática a metodologia científica e que reconheçam alguns elementos da natureza como indicadores da poluição gerada pelo próprio homem

Objetivo(s) específico(s): promover o despertar para a ciência; possibilitar o contato dos educandos com a metodologia simples, na prática do teórico; possibilitar que o educando seja agente observador, crítico e detentor de cultura e prática científica.

Plano de ação (metodologia, conteúdos, atividades): 1. avaliar quais os fatores a serem estudados dentro do Parque Ecológico Cotia Pará referente à poluição do ar, água e sonora;2. buscar possíveis bioindicadores na própria flora e fauna do parque.3. criar atividades práticas de curto e longo prazo, aplicável com os educandos que nos visitam. 4. criar um elo interdisciplinar com as escolas para dar continuidade ao trabalho de pesquisa científica 


\section{Anexo E 1}

Curso Poluição e Saúde - Projetos Ambientais e a Escola

\section{Perfil do professor}

1. Nome:

2. Escola:

3. a.( ) Rede Municipal de Cubatão b.( ) Rede Estadual de São Paulo

4.Tel. contato:

5.Séries em que leciona:

a. Ensino Fundamental : 1.( ) 1 $1^{\mathrm{a}}$ a $4^{\underline{a}}$ séries $\quad 2 .\left(\quad\right.$ ) $5^{\underline{a}}$ a $8^{\underline{a}}$ séries

b. Ensino Médio ( )

6. Disciplinas que leciona:

a. $5^{\mathrm{a}}$ a $8^{\mathrm{a}}$ séries

b. Ensino Médio

7.Você desenvolve algum projeto de Educação Ambiental na sua escola?

a. ( ) sim

b. ( ) não

a.1. Se sim, descreva sucintamente, no verso, as principais atividades e objetivos do projeto.

8. Você já desenvolveu algum projeto de Educação Ambiental em sua escola?
a. ( ) sim
b. ( ) não

a.1.Se sim, quando?

a.2.Descreva sucintamente, no verso, as atividades e objetivos do projeto.

9. Você já participou de alguma formação em Educação Ambiental?
a. ( ) sim
b. ( ) não

Se sim, responda:

a.1. curso - tema :

em que ano? Instituição:

a.2. oficina - tema : em que ano? Instituição:

a.3. palestra - tema : em que ano? Instituição:

OBS: 


\section{Anexo E 2}

\section{Avaliação}

\section{Curso Poluição e Saúde - Projetos Ambientais e a Escola}

Nome: Escola:

Encontramo-nos na metade do curso e gostaríamos que pudéssemos avaliar em conjunto se os objetivos aos quais nos propusemos estão, até o momento, sendo alcançados.

Para tanto, lembramos os objetivos principais do curso:

"Este curso é oferecido aos professores de Ensino Fundamental e Médio, com aulas ministradas pela equipe do LPAE e professores da Universidade de São Paulo, tendo como objetivos, em um primeiro momento sensibilizar e, seqüencialmente, dar o suporte teórico necessário para o desenvolvimento de projetos, a serem realizados com os alunos, pelos professores capacitados. Em contrapartida, educadores, designados pela DERS, farão o acompanhamento e a supervisão dos projetos, dentro das próprias escolas, funcionando como "facilitadores", incluindo aí, a busca de parcerias que possam auxiliar no desenvolvimento e execução das atividades planejadas."

Dentro destes objetivos, como você avalia as aulas:

29/05 - Possibilidades de Projetos na Escola - Prof. Dr. Paulo Saldiva 
06/09 - Metodologia de Projetos - Prof ${ }^{a}$. Drª . Martha Marandino

15/09 - Epidemiologia Ambiental -Prof. Dr. Alfésio Braga

15/09 - Apresentação do LPAE - Prof ${ }^{a}$. Débora Lobo

23/09 - Reprodução, Gestação e Poluição - Prof. Dr. Luiz Alberto Pereira

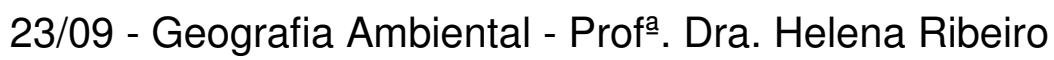

29/09 - Biomonitoramento de Ozônio - Prof ${ }^{a}$. Dra. Marisa Domingos

Avaliação do curso até o momento: 
Anexo E 3

\section{Avaliação}

Curso Poluição e Saúde - Projetos Ambientais e a Escola

Nome: Escola:

1. Cite os principais pontos positivos:

2. Cite os principais pontos negativos:

3. O curso trouxe contribuições para a aplicação de projetos de Educação Ambiental ? Justifique

4. Outros comentários/sugestões:

5. O curso foi:

( ) excelente ( ) bom ( ) satisfatório ( ) ruim 


\section{REFERÊNCIAS}

1 Kuhn TS. A estrutura das relações científicas. Tradução Boeira BV, Boeira N. - São Paulo: Perspectiva; 1983.

${ }^{2}$ Chassot A. A ciência através dos tempos. São Paulo: Moderna; 1994 (Coleção Polêmica).

3 Reis J. Divulgação científica. Revista Espiral. Núcleo José Reis de Divulgação Científica. №. 27 - abr-mai-jun 2006. [on line] [citado 28 mar 2007]. Disponível em:

http://www.eca.usp.br/nucleos/njr/espiral/more27b.htm

4 Souza CM, Silveira TS. Como a mídia impressa paulista divulga ciência e tecnologia. Revista Ciências Humanas - UNITAU. Vol. 7 n². 2001. [on line] [citado 05 mar 2007]. Disponível em: http://www.unitau.br/prppg/publica/humanas/revista_v7_n2_2001.htm

5 Hospital das Clínicas da Faculdade de Medicina da Universidade de São Paulo. Laboratórios de Investigação Médica Hospital das Clínicas da FMUSP. Home page. [on line] [citado 09 dez 2007]. Disponível em: http://www.direxlim.fm.usp.br/index.php

6 Böhm GM. Editorial. J Pneumol. 1987; 13(3).

7 Revista do InCor. São Paulo: 1996:2 (17).

8 Freire P. Pedagogia do oprimido. $17^{\mathrm{a}}$ ed.-Rio de Janeiro: Paz e Terra; 1987.

9 Moraes AC. Mídia e escola: relações necessárias. Petrópolis, RJ: Vozes; 2004.

${ }^{10}$ Brasil. Presidência da República - Casa Civil - Subchefia para Assuntos Jurídicos [on line] [citado 03 jan 2007] . Disponível em: http://www.planalto.gov.br/ccivil/Leis/L9795.htm

${ }^{11}$ Figueiredo RS. A interface com a Educação Ambiental. In: Brum E, Farias $\mathrm{R}$, organizadores. A mídia do Pantanal. Campo Grande: UNIDERP, 2001. p.195-208.

${ }^{12}$ Chevallard Y. La transposición didáctica: del saber sábio al saber enseñado . Argentina: Aique; 1991.

${ }^{13}$ Perrenoud P. Práticas pedagógicas, profissão docente e formação: perspectivas sociológicas. Lisboa: Dom Quixote, 1993. 
${ }^{14}$ Marandino M. O conhecimento biológico nas exposições de museus de ciências: análise do processo de construção do discurso expositivo [tese]. São Paulo, SP: Faculdade de Educação, Universidade de São Paulo; 2001.

${ }^{15}$ Ludke M, André M. Pesquisa em Educação: abordagens qualitativa São Paulo: EPU; 1986.

${ }^{16}$ Triviños ANS. - Introdução à pesquisa em Ciências Sociais - a pesquisa qualitativa em educação. 4. ㄹ edição. São Paulo: Atlas; 1995.

${ }^{17}$ Chizzotti A. Pesquisa em Ciências Humanas e Sociais. São Paulo: Cortez; 1998.

${ }^{18}$ Alves-Mazzotti AJ. O método nas Ciências Sociais. In: Alves-Mazzotti AJ e Gewandsnajder F. O método nas Ciências Naturais e Sociais: pesquisa quantitativa e qualitativa. São Paulo: Pioneira; 1998. p.107-203.

${ }^{19}$ Bauer MW, Gaskell G. - Pesquisa qualitativa com texto,imagem e som um manual prático - tradução Guareschi, PA - Petrópolis; Vozes, 2002.

${ }^{20}$ Gamboa SS - Quantidade - qualidade: para além de um dualismo técnico e de uma dicotomia epistemológica. In: Santos Filho e Gamboa SS, organizadores - Pesquisa educacional: quantidade - qualidade - 4a. ed. São Paulo; Cortez, 2001. p.84 -110.

${ }^{21}$ Teixeira E. As três metodologias: acadêmica, da ciência e da pesquisa. 5ㄹ ed. Belém: UNAMA; 2001

22 Moles A. Mass communication: encyclopedic dictionary of semiotics, T.A. Sebeok et al.- Berlim: Mouton de Gruyter; 1986.

${ }^{23}$ Massarani L, Moreira IC. A retórica e a ciência: dos artigos originais à divulgação científica. Ciência\&Ambiente. Divulgação Científica. jul/dez 2001; n. 23: p. $52-79$.

${ }^{24}$ Costa Bueno W. Jornalismo científico e o compromisso das fontes Portal do jornalismo científico [on line] [citado 26 out 2005]. Disponível em: http://www.jornalismocientifico.com.br/artigowilbuenojcfontes.htm

${ }^{25}$ Santaella L. Cultura das mídias - São Paulo: Experimento; 1996.

${ }^{26}$ Ozório AM. A vulgarização do saber. - Rio de Janeiro: Ariel; 1931. 
${ }^{27}$ Díaz JV. Divulgacion científica y democracia. In: Alambique - didáctica de Lãs Ciencias Experimentales. № 21, Ano VI, julio, 1999. p. 17-25

${ }^{28}$ Wynne B. Saberes em contexto. In: Massarani L, Turney J, Moreira I, organizadores. Terra incógnita: a interface entre ciência e público. - Rio de Janeiro: Vieira \& Lent: UFRJ: Casa da Ciência: FIOCRUZ; 2005. p. 27-39.

${ }^{29}$ Nieto MO. El público y las políticas de ciencia y tecnología. In: Asociación Interciencia. fev. 2002; vol.27, ํo.2: p.80-83.

${ }^{30}$ Myers G. Discourse studies of scientific popularization: questioning the boudaries. Discourse Studies. (Londres) SAGE Publications; 2003; 5 (2), p. 265-279.

${ }^{31}$ Lévy-Leblond JM. Cultura científica: Impossível e Necessária. In: Vogt C, Organizador. Cultura Científica: Desafios - São Paulo: Edusp/Fapesp; 2006. p. 28-43.

32 Durant J. Participatory technology assessment and the democratic model of the public understanding of science. Science and Public Policy. 1999; 26 (5). p. 313-9;

${ }^{33}$ Miller S. Os cientistas e a compreensão pública da ciência. In: Massarani L, Turney J, Moreira I, organizadores. Terra incógnita: a interface entre ciência e público. - Rio de Janeiro: Vieira \& Lent: UFRJ: Casa da Ciência: FIOCRUZ; 2005. p.115-132.

${ }^{34}$ Lewenstein BV, Brossard D. Assessing models of public understanding. ELSI Outreach Materials. U.S. Departament of Energy Grant: Final Report Cornell: Cornel University , 2006

${ }^{35}$ Krasilchik M, Marandino M. Ensino de ciências e cidadania. São Paulo : Moderna, 2004.

${ }^{36}$ Marandino M, Silveira RVM,Chelini MJE et al. A Educação Não Formal $e$ a Divulgação Científica: o que pensa quem faz?. In: IV Encontro Nacional de Pesquisa em Ensino de Ciências. Atas do IV Encontro Nacional de Pesquisa em Ensino de Ciências - Bauru: ENPEC; 2004.

${ }^{37}$ Lewenstein, BV. Models of public communication of science and technology. Version: jun 2003 [on line] [citado em 20 jun 2007]. Disponível em:

<http://communityrisks.cornell.edu/BackgroundMaterials/ Lewenstein2003.pdf>l 
${ }^{38}$ Lozano M. Programas y experiencias en popularización de la ciência y la Tecnologia: Panorâmica de los países del Convenio Andrés Bello Bogotá: CAB; 2005.

39 Auweraert V. Dimensions of Science Communication. 8th Conference of the International Network on Public Communication of Science and Technology, PCST-8. Barcelona, Espanha, Junho de 2004. [on line] [citado 20 jun 2007]. Disponível em: http://www.pcst2004.org/ing/pdf/Parallel_Session_9.pdf

${ }^{40}$ Silva EP, Camargo JC, Sordi A, Santos AMR. Recursos energéticos, meio ambiente e desenvolvimento. MultiCiência - Revista Interdisciplinar dos Centros e Núcleos da Unicamp. out 2003;1. [on line] [citado 21 mar 2007] . Disponível em: http://www.multiciencia.unicamp.br/art04_i.htm

${ }^{41}$ Teixeira A. Pequena introdução à filosofia da educação:escola Progressista ou a transformação da escola. São Paulo:Melhoramentos, 1968.

${ }^{42}$ Brasil. Ministério da Educação, Secretaria de Educação Fundamental. Programa parâmetros em ação, meio ambiente na escola. Brasília: MEC/SEF, 2001. (caderno de apresentação)

${ }^{43}$ Pesavento SJ. O Brasil contemporâneo. Porto Alegre: Editora da Universidade - UFRGS, 1991.

${ }^{44}$ Bittencourt CMF. A proposta de Educação Ambiental e as muitas dúvidas In: Pontuschka, NN, organizadora. Um projeto... tantas visões Educação

Ambiental na escola pública - São Paulo: Lapech - Feusp/AGB; 1996. p. 9-16.

${ }^{45}$ Brasil. Ministério da Educação, Secretaria de Educação Fundamental. Parâmetros Curriculares Nacionais: terceiro e quarto ciclos: apresentação dos temas transversais. Brasília: MEC/SEF, 1998. p. 169-233 : Meio Ambiente

${ }^{46}$ Loureiro CFB. Trajetória e Fundamentos da Educação Ambiental - São Paulo: Cortez; 2004.

${ }^{47}$ Cascino F. Educação Ambiental: Princípios, História e Formação de Professores - São Paulo: SENAC SP; 2004.

${ }^{48}$ Guimarães M. A Formação de Educadores Ambientais - Campinas, SP: Papirus; 2004 (coleção Papirus Educação). 
${ }^{49}$ Carvalho ICM. Educação Ambiental: A Formação do Sujeito Ecológico - São Paulo: Cortez; 2004.

${ }^{50}$ Gadotti M. Pedagogia da Terra - São Paulo: Peirópolis; 2000.

${ }^{51}$ Sorrentino M. - De Tbilisi a Thessaloniki. A Educação Ambientalno Brasil. In: Cascino F, Jacobi P, Oliveira PJF, organizadores. Educação, Meio Ambiente e Cidadania: Reflexões e Experiências - São Paulo: Secretaria do Meio Ambiente / CEAM; 1998. p. 27-32.

52 Tristão M. A educação ambiental na formação de professores: rede de saberes. São Paulo: Annablume; Vitória: Facitec, 2004.

${ }^{53}$ Grabiel CM. Usos e abusos do conceito de transposição didática (Considerações a partir do campo disciplinar da história). Anais IV Seminário Perspectivas do Ensino de História. Universidade Federal de Ouro Preto; 2001. [on line] [citado 21 mar 2007] . Disponível em: http://www.ichs.ufop.br/perspectivas/anais/GT0509.htm

${ }^{54}$ Thiollent MJM. Critica metodológica; investigacion social e enquête Operária - 2ª ed.- São Paulo: Polis; 1981.

${ }^{55}$ Richardson RJ. Pesquisa Ação: Princípios e Métodos - João Pessoa, UFPB; 2003

${ }^{56}$ Michaliszyn MS, Tomasini R. Pesquisa: orientações e normas para elaboração de projetos, monografias e artigos científicos. Petrópolis: Vozes; 2005.

${ }^{57}$ Rede Globo [on line] [citado 07 fev 2006]. Disponível em: http://redeglobo3.globo.com/institucional/

${ }^{58}$ Rede Cultura de Televisão [on line] [citado 07 fev 2006]. Disponível em: http://www.tvcultura.com.br/detalhe_institucional.aspx?id=51

${ }^{59}$ Google [on line] [citado 30 jun 2007]. Disponível em: www.google.com.br

${ }^{60}$ Yahoo! Search [on line] [citado 30 jun 2007]. Disponível em: http://br.busca.yahoo.com/

${ }^{61}$ AltaVista [on line] [citado 30 jun 2007]. Disponível em: http://br.altavista.com/web/adv

${ }^{62}$ Altheweb [on line] [citado 30 jun 2007]. Disponível em: www.alltheweb.com 
${ }^{63}$ StarMedia [on line] [citado 30 jun 2007]. Disponível em:

http://busca.starmedia.com/search

${ }^{64}$ Peters PH. A Interação Entre Jornalistas e Especialistas Científicos: Cooperação e Conflito Entre Duas Culturas. In: Massarani L, Turney J, Moreira I, organizadores. Terra incógnita: a interface entre ciência e público. Rio de Janeiro: Vieira \& Lent: UFRJ: Casa da Ciência: FIOCRUZ; 2005 . p.139-60.

${ }^{65}$ Cidoval MS. Comunicação, Ciência e Sociedade. Site Portal do Jornalismo Científico [on line] [citado out 292007]. Disponível em: http://www.jornalismocientifico.com.br/jornalismocientifico/artigos/ jornalismo_cientifico/artigo6.php

${ }^{66}$ Brasil. Ministério da Ciência e Tecnologia, Secretaria de C\&T para Inclusão Social. Percepção Pública da Ciência e Tecnologia [on line] [citado 20 out 2007]. Disponível em:

http://www.mct.gov.br/index.php/content/view/50877.html

${ }^{67}$ Marandino M. A. Pesquisa Educacional e a Produção de Saberes nosMuseus de Ciências. História, Ciência e Saúde . 2005;12. (Suppl. Museus e Ciências).p.161-81.

${ }^{68}$ Perrenoud P. Formar professores em contextos sociais em mudanças: prática reflexiva e participação crítica. Revista Brasileira de Educação.setdez 1999: 12: p.5-21.

${ }^{69}$ Quintas LP. Um ensaio sobre a relação da teoria de Vygostsky e os cursos de capacitação de professores. Jornal Subsídio. mar 2006; 6-7.

70 Jacobi PR. Comitê de Bacias Hidrográficas - Dimensão Político Social. [on line] [citado 18/01/2008] . Disponível em: http://www.agds.org.br/midiaambiente/pdf/jacobi.pdf 